University of Louisville

ThinkIR: The University of Louisville's Institutional Repository

Electronic Theses and Dissertations

1943

\title{
An investigation into the need and the use of patriotic holiday reading material in the primary grades.
}

Mary Walker Barnard 1906-1996

University of Louisville

Follow this and additional works at: https://ir.library.louisville.edu/etd

Part of the Civic and Community Engagement Commons, Educational Methods Commons, and the Politics and Social Change Commons

\section{Recommended Citation}

Barnard, Mary Walker 1906-1996, "An investigation into the need and the use of patriotic holiday reading material in the primary grades." (1943). Electronic Theses and Dissertations. Paper 1681.

https://doi.org/10.18297/etd/1681

This Master's Thesis is brought to you for free and open access by ThinkIR: The University of Louisville's Institutional Repository. It has been accepted for inclusion in Electronic Theses and Dissertations by an authorized administrator of ThinkIR: The University of Louisville's Institutional Repository. This title appears here courtesy of the author, who has retained all other copyrights. For more information, please contact thinkir@louisville.edu. 


\title{
UNIVERSITY OF LOUISVILLE
}

\author{
An Investigation \\ Into the Need and the Use of \\ Patriotic Holiday Reading Material \\ in the Primary Grades \\ A Dissertation \\ Submitted to the Faculty \\ of the Graduate School of the University of Louisville \\ In Partial Fulfillment of the \\ Requirements for the Degree \\ of Master of Arts
}

Department of Education

by

Mary Walker Barnerd

Year

1943 
INAME OF STUDENT: Mary Walker Barnard

TITIE OF THESIS: An Investigation Into the Need and the Use of Patriotic Holiday Reading Material in the Primary Grades

APPROVED BY READING COMNITTEE CONPOSED OF THE POLIOWING MEMIBERS:

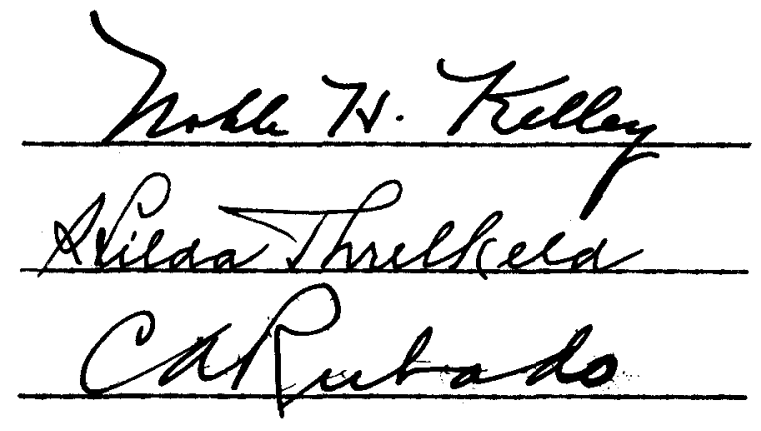

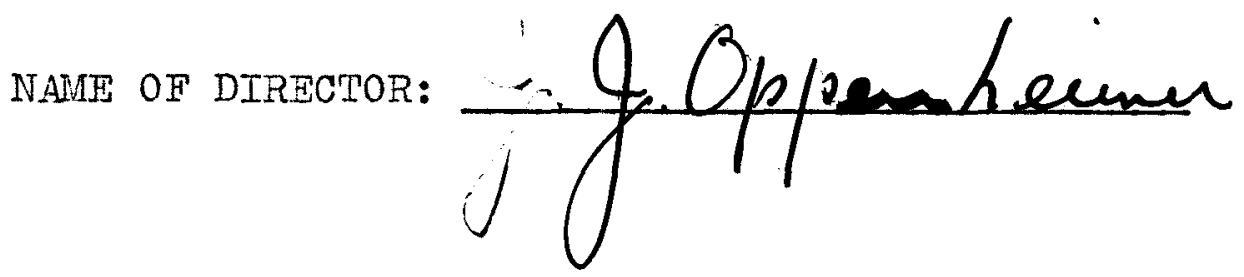
DATE: Quq:17,1943 


\author{
An Investigation \\ Into the Need and the Use of \\ Patriotic Holiday Reading Material \\ in the Primary Grades
}




\section{Table of Contents}

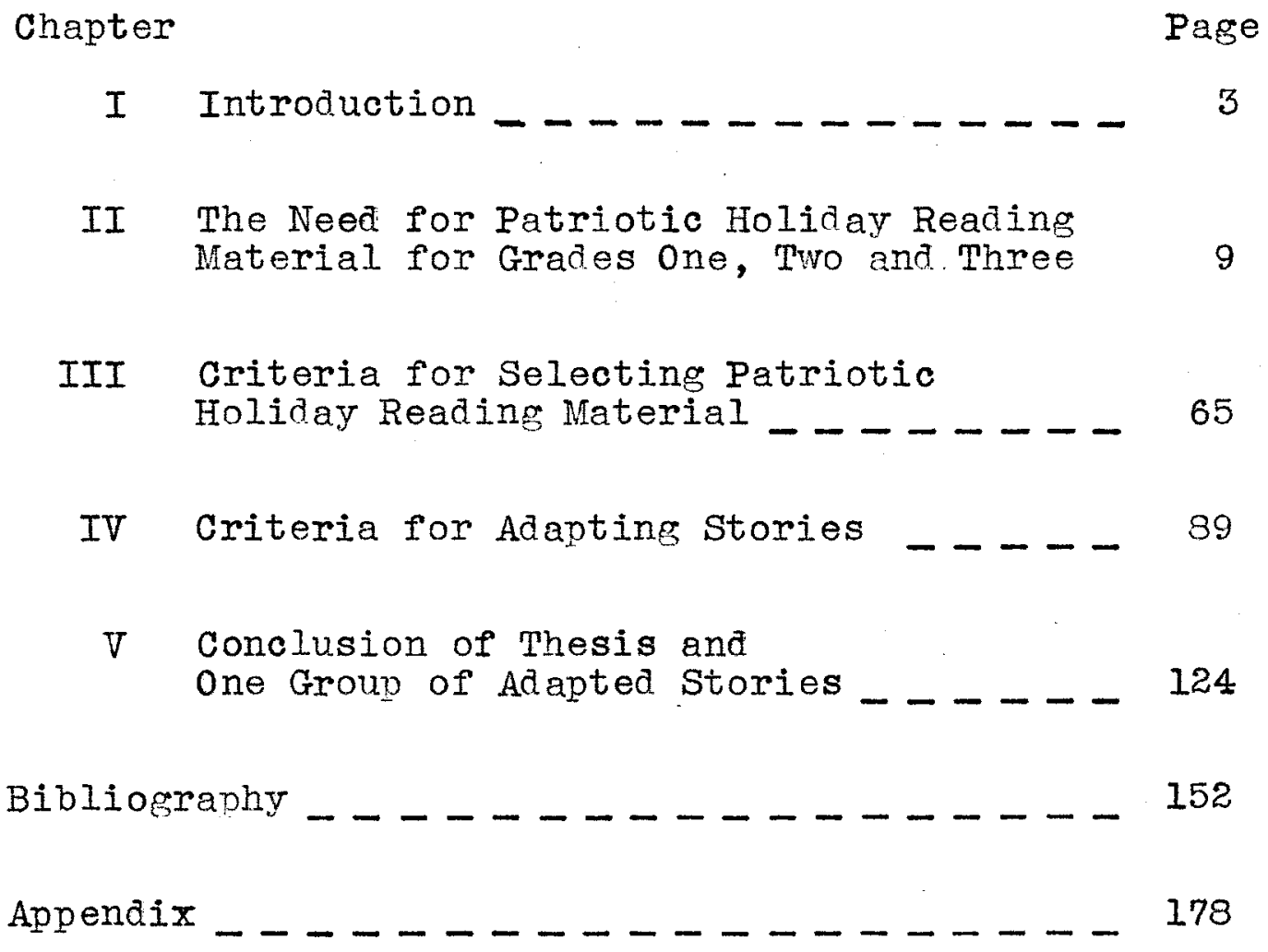


List of Tables

Table

I A Survey of Forty-four Present Day Textbooks

(Grades One, Two and Three) for Patriotic

Holiday Reading Material 1935-1941

II A Survey of Needs for Patriotic Holiday Reading Material by 239 Primary Teachers of the Louisville Public Schools

III A Survey of IVeeds for Patriotic Holiday Reading Material by 268 Primary Teachers in the State of Kentucky Including Louisville

IV A Survey of the Needs for Patriotic Holiday Reading Material by 34 Primary Teachers of Ten Schools from the States of Georgia, Illinois, Ohio, Kentucky and Virginia. (Iouisville is Not Included in Kentucky).

$\checkmark$ Tentative Criteria To Be Used in Selecting Patriotic Holiday Reading Material for Grades One, Two and Three

VI Summary of Responses of Seventeen Teachers to the Questionnaire on First Revision of

"When Columbus Was a Little Boy"

VII Summary of Responses of Seventeen Teachers to the Questionnaire on First Revision of "An Old Dream and a New One"

VIII Summary of Responses of Seventeen Teachers to the Questionnaire of First Revision of "Trying to Make a Great Dream Come True"

IX Summary of Responses of Seventeen Teachers to the Questionnaire on First Revision of "A Great Dream Comes True"

$X$ Summary of Responses of Seventeen Teachers to the Questionnaire of First Revision of "The Natives of San Salvador"

XI Summary of Responses of Seventeen Teachers to the Questionnaire on First Revision of "The Return of the Mad Sailor"

XII Summary of Responses of Seventeen Teachers to the Questionnaire of First Revision on "The Simplost Thing in the World"

XIII Word Rating of the Second Revision of the Columbus Day Stories According to Gates 


\section{Chapter I}

Introduction 
Statement of the Problem. The investigation and study given to this paroblem are an outgrowth of eighteen years of experience and careful observation in the primary grades in the Louisville Public Schools. The dearth of patriotic holiday reading material for the primary grades necessitated this investigation. It is a study of the needs for such reading material; a collection and evaluation of the available material; adaptations of this material to the needs of grades one, two and three; an analysis of the findings resulting from the classroom use of some of these adaptations; and further adaptations based upon the findings of the analysis.

Steps in the Solution of the Problem. The steps taken in attempting to solve the problem are as follows:

1. to find out whether the teachers in these grades feel the need for additional material of this type; 2. to collect available patriotic holiday reading materials on primary levels; 
3. to collect materials of this type on upper grade, secondary school, and adult levels, with the idea of adapting the stories for use in lower grades;

4. to set up standards for evaluating and analyzing the collected materials;

5. to analyze the collected materials in order to determine their suitability for use in these grades; 6. to set up standards for rewriting materials which need to be adapted;

7. to make necessary adaptations;

8. to put the adapted material to the test of actual use in seventeen classrooms in Louisville;

9. to analyze findings resulting from classroom use; 10. to write further adaptations based upon the findings of the analysis.

Methods Used. In Chapter Two, the survey method has been used. The summary of the results of surveys proves:

1. that teachers believe that it is desirable to use much patriotic holiday reading material;

2. that there is a dearth of such material.

1 Good, Barr, Scates, The Methodology of Educational Research. p. 287 
The survey and questionnaire methods ${ }^{1}$ have been used in Chapter Three. Courses of Study from all parts of the United States were surveyed in order to determine the extent to which patriotic holidays were emphasized. Questionniares were sent to forty-six primary supervisors and superintendents in order to discover the reason for the apparent lack of emphasis upon this topic.

Also, in Chapter Three, criteria for evaluating patriotic holiday reading material for grades one, two and three have been suggested. The criteria set up in this chapter resulted from a survey of the courses of study which included patriotic holiday plans. Questionnaires were sent to forty-six primary supervisors and superintendents for this evaluation of the criteria.

The methods used in Chapter Four are: the survey method, the analytical method, and the questionnaire method. First, a survey was made of the material in library books, school texts, and teachers' private collections. The analytical method was used

1

Good, Barr, Scates, The Methodology of Educational Research, p. 295

2

Ibid., p. 220 
in determining which ones of the available stories met the standards for use in primary grades. The questionnaire method was used in the evaluating of Columbus Day stories in seventeen classrooms of Louisville. This was followed up by the writing of the second revision of the Columbus Day stories based on the suggestions made by the pupils and teachers who had used the material in their classrooms. Chapter Five has two parts. Part one is "Conclusions of this Thesis". Part Two includes a group of Columbus Day stories. In Part Two, the sampling method was used. The writer of this thesis has adapted stories based on each of the patriotic holidays. In Chapter Five she submits, as a sampling which will illustrate her method, a group of Columbus Day stories.

The most commonly observed patriotic holidays in the United States are: Columbus Day, Armistice Day, Thanksgiving Day, Abraham Isincoln's Birthday, George Washington's Birthday, Memorial Day and Flag Day.

The surveys, story collection and adaptation of materials were made in the hope of giving a deeper appreciation of our patriotic holidays. By linking the American hero days with all the days between,

1

Good, Barr, Scates, the Methodology of Educational Research, p.220. 
we hope to lead children to develop a sturdy spirit of Americanism which will help then to be true to themselves, to their fellowmen, and to their country's ideals. 


\section{Chapter II}

The Need For Patriotic Holiday Reading Material for Grades One, Two and Three 
The Need for Patriotic Holiday Reading Material

for

Grades One, Two and Three

The Desirability of Such Material. Primary children pause as they face the "red-lettered" days on the calendar and ask, "Why do we "red-letter" these days?"

These "red-lettered" days have been set apart

for the purpose of paying tribute where tribute is

due. Some patriotic holidays are days for the celebration of the birthdays of those Americans of whose deeds we are proud. Some are days for renewing allegiance to the ideals of our country and our forefathers. others are days when we should think of and express our gratitude for the blessings of the past year. In celebrating these days, there are unlimited possibilities for influencing the lives of our chilaren.

Just as families set aside birthdays to show in special ways appreciation of loved ones, so our United States Government sets aside certain days for the expression of our appreciation of great Americans. The spirit of one of these holidays should not be limited to a twenty-four hour day but should have carry- 
over value for the other three hundred and sixty-four days of the year. Thus, they should help to develop patriotic citizens.

Patriotism is bought neither by the pound nor by the yard. It is not bought at all. It lies deeper than the material commodities which can be bought and sold. It is a part of the very soul of an individual. It should deepen with experience and with the understanding of the principles upon which one's country has been founded. Patriotism involves intelligence and consecration to one's country. Citizens who possess these qualities do not arise by accident. They are born anew in each generation and are the products of home, school, church and community. Our patriotic holidays afford opportunities for special emphasis in a year round program for developing good citizens.

Patriotism grows and builds a greater country.

"There is no better way to teach citizenship than to establish in the hearts of youth a love of the great men and women who have dreamed and worked and sacrificed to build our Republic. It is important that youth understand the ideas and ideals along with the events in these lives." I

1

Joy Elmer Horgan, "Between Editor and Reader", The Journal of the National Education Association, $\overline{\mathrm{XXX}}$ : II (February,I941), p. 2I. 
Appropriate patriotic stories which the children can read for themselves can contribute much toward this fine type of citizenship teaching.

"The flag means that you cannot
be saved by the valor and the de-
votion of your ancestors; that to
each generation comes the patriot-
ic duty; and that upon your will-
ingness to sacrifice and endure
as those before you have sacri-
ficed and endured rests the na-
tional hope."1

One cannot truly appreciate and understand these sacrifices of ancestors and the responsibility that is his as a citizen unless he is informed. Patriotic holiday material is one of the more attractive and interesting means of providing this information. Observing all the patriotic holidays gives experiences which should emphasize true love for one's country. Deeper respect should be brought about through understanding, sympathy and knowledge of the ideals of our forefathers and the price paid for their preservation.

The school program of most value is the one which results from the creative genius of the children. For example, if the children live the life of Columbus in imagination provoked by reading and discussing his accomplishments, they will create

1

Charles Evans Hughes, "The United States Flag Code", The Journal of the National Education Association, XXX:II (February, I94I), p. 37 . 
their own program and express it in costume, tableaux, music, composition, acting and dialogue. The merit of the Columbus Day program will lie in its leading children, through their own expression, to a better understanding of their ow country, and to a broader conception of patriotism.

The Dearth of Such Material. The dearth of patriotic holiday reading materials which are on the levels of the first, second and third grades is significant. The following survey of forty-four present day textbooks which are available for grades one, two and three has been made. The data are presented in Table I which includes the names of the forty-four textbooks." These forty-four textbooks include two thousand seventy-one stories.

The table shows that these textbooks include:

13 Thanksgiving stories and I poem

11 Washington stories

4 Columbus stories and 1 poem

5 Lincoln stories

0 Armistice Day stories and poems

o Memorial Day stories and poems

6 Flag poems which could be used on Flag Day Out of the two thousand seventy-one stories in these forty-four present day textbooks, there is 1.6 percent of the material which would be available for patriotic holiday use.

Table I follows. 


\section{A Survey of Forty-four Present Day Textbooks (Grades One, Two and Three) \\ For Patriotic Holiday Reading Material 1935 - 1941}

Number of stories and poems Titlㅡㅇoㅇ Textbooks _ for_use_for_the_Patriotic_Holidays

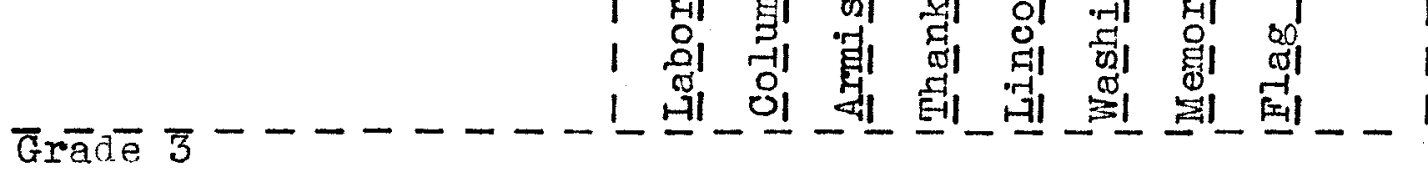

If I I Were Going Friendly_Village.

Grade $\bar{I}$

Round About

Gràde $\overline{3}$

Friends To Know

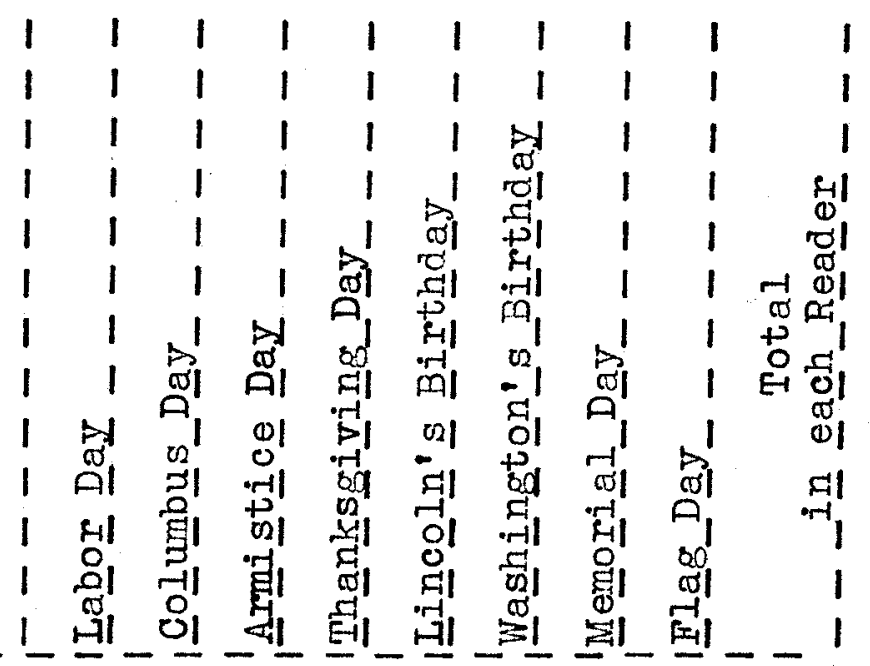

Gràdē $\overline{2}$

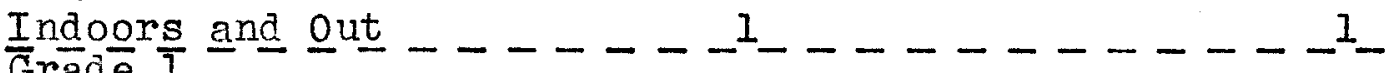

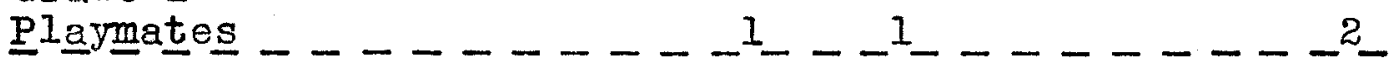

Primer

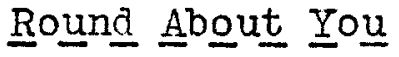

Near_and_Far.

At Home and away

$\bar{G} \bar{a} \bar{\theta} \overline{3}$

Friends Around the World

$\bar{G} r \bar{a} d \bar{e} \bar{L}$

Friends Here and Away

Grade I Frieñds in

Town_and_Country

Primer

*

Poom 
Number of stories and poems Titles_of Textbooks - - f for use for the Patriotic Holidays

Pre-Primer $\ldots-\ldots-\ldots-\ldots-\ldots{ }^{1}-\ldots-\ldots-1^{1}$ Enchanting_Stories

Faraway Ports

The Story Road _ $\ldots \ldots \ldots \ldots \ldots$

Along the Way

Good_Stories

I Know ${ }^{a}$ S Secret

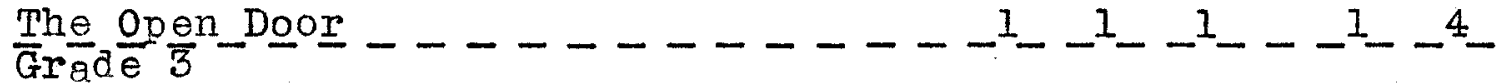
New Trails $\frac{\text { Tin Regding }}{2}$ …

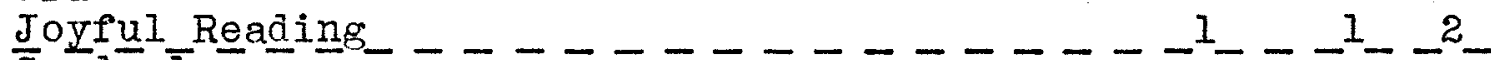
Grade I

Webster Reader

Grāe $\overline{3}$

Meeting our Neighbors

Grade 2

Making Vi吕ts

$\bar{G} \overline{r a} \bar{e} \bar{I}$

Finding Friend

Grade $\frac{1}{3}$

Let's Read

We_Look Around_US $\ldots \ldots \ldots-\ldots-\ldots{ }^{1} \ldots \ldots-\ldots-\ldots$

1

Published in 1927

*

Poems 
Number of stories and poems

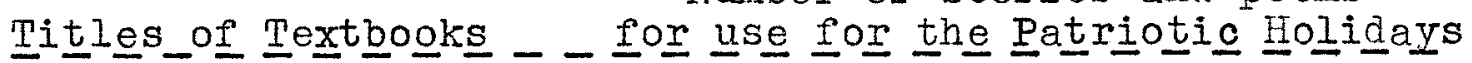

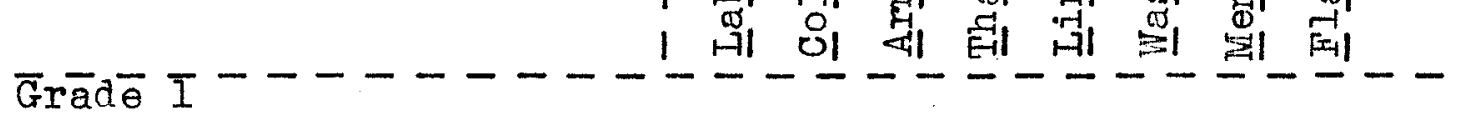

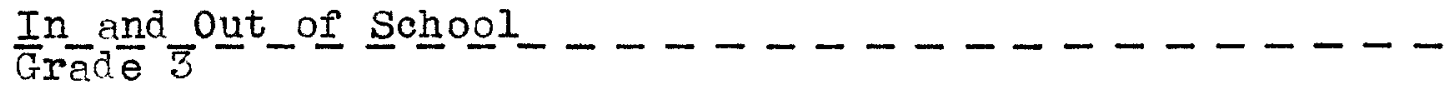

Neighbors and Helpers $\ldots \ldots \ldots \ldots$

Grade $\overline{2}$

Friends About Us

Grāa e I

Good_Times_Together

Grāa $\bar{e} \overline{3}$

Wide Wings $\ldots \ldots-\ldots-\ldots-\ldots-\ldots-\ldots$

$\bar{G} r \bar{a} d \bar{e} \bar{z}$

We_Grow Up

Gräēe I

Down Our Street

Book-3 - Stret - - - - - -

Happy Hour_Reader

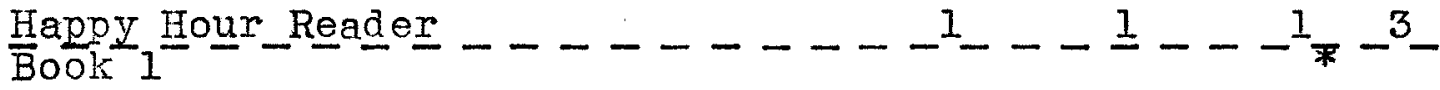

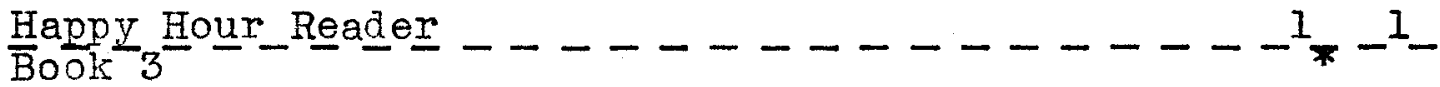

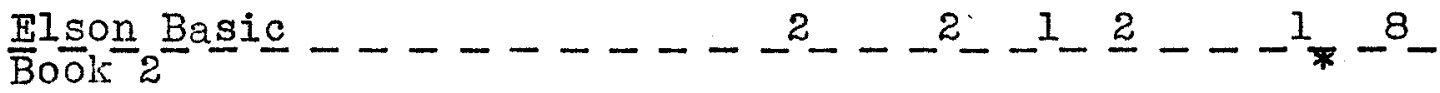
Elson Basic $\ldots \ldots \ldots$ Book 1

Elson Basic

Grade $\overline{3}$

All Aboard_for_Storyland

Pooms 
This survey of present day textbooks shows that most of the information about these holidays must be gleaned from home or from information given by the teacher and not from textbooks. George Washington's Birthday and Thanksgiving Day have the greatest number of stories. Not all the Thanksgiving stories relate to the First Thanksgiving. Many stories bring out the real Thanksgiving spirit but do not give historical background.

Failure of courses of Study to Make Use of Such Materials. Following the survey of the textbooks, twenty-one courses of study were examined. The purpose of this survey is to show the emphasis placed on patriotic holiday activities in the school rooms of four sections of the United States. They are the Western, Central, Southern and Eastern Sections.

The courses of study are listed according to the sections of the United States which they represent. Activities and school room experiences are listed under each course of study according to patriotic holidays. Failure of nine courses of study to make use of patriotic holiday materials is observed and listed. Seven courses of study list limited suggestions for patriotic holiday activities. Five 
courses of study list in detail suggestions for the observance of the patriotic holidays.

Suggestions for classroom activities on patriotic holidays are summarized on the following pages. These suggested activities are from the twelve courses of study examined and which listed activities for grades one, two and three, relating to patriotic holidays. It is desired by the writer that the meticulous summary of these classroom activities will serve in the future as a suggestive guide for primary teachers in their planning for patriotic holidays.

Twenty-one courses of study have been examined and the following information obtained therefrom:

I Nine omit all plans for school experiences related to patriotic holidays. They are:

1. Cleveland, Ohio, 1927-1929

2. Denver, Colorado, 1931

3. Long Beach, California, $1930^{1}$

4. Milwaukee, Wisconsin, 1936-1937

5. Oklahoma City, Oklahoma, 1936-1937

6. Pasadena, California, 1936

7. State of Indiana, 1930

3. Iowa State Course of Study for Elementary Schools, 1930

1

A brief bibliography of holiday stories is given in the back of this Course of Study 
9. Virginia State Course of Study, 1937

II Seven include such activities with limited suggestions. They are:

1. California State Department of Education (Sacramento), 1922

2. Cincinnati, Ohio, 1926

3. Detroit Public Schools, 1925

4. Los Angeles, California, Grade 2, 1924

5. Minneapolis, Minnesota, 1935

6. Raleigh, North Carolina, (Grades 1,2, and 3 ) 1928-1931

7. Raleigh, North Carolina, Social Courses of Study, 1936

III Five suggest activities and real life experiences in a full and detailed manner. They are:

1. Baltimore, Maryland, (County) 1937

2. Fort Worth, Texas, 1935

3. Kansas City, Missouri, 1930

4. Louisville, Kentucky, A Preliminary Course of Study in English for Kindergarten-Primary Grades, 1940

5. St. Louis, Missouri, 1926 
IV A survey of the above courses of study reveals the fact that, the following suggestions are made for patriotic holiday activities.

A In the Western States

1. California State Department of Education Bulletin - 2 - D

Suggested State Course of Study for Kindergarten and Primary Grades, Sacramento, 1922. Suggested Activities

Studying the manners, customs, and ideals of our people. Patriotic holidays suggested to be included in study by grades are:

Grade 1

a. Thanksgiving

b. Lincoln

c. Memorial Day

d. Flag Day

Grade 2

a. Columbus Day

b. Thanksgiving Day

c. Lincoln

d. Memorial Day

e. Flag Day 
Grade 3

Same as Grades 1 and 2

No activities or plans for study are

suggested for Grades $I$ and 3 .

2. Kansas Gity, Missouri, 1930

Social Studies for Primary Grades

Curriculum Bulletin No. 8

Kansas City Public Schools

Suggested Activities

Grade 1

a. Washington's Birthday

Real life experiences and interests

(1) Seeing pictures of Washington in store windows

(2) Having a patriotic parade

(3) Attending a school play on colonial times

(4) Helping Mother prepare for a Washington party

(5) Watching cadets drill

(6) Reading picture section in paper

(7) Attending a Boy scout Rally

Related activities for school room

(1) Listening to and interpreting the minuet

(2) Making a collection of Washington's pictures

(3) Comparing present-day with past customs

(4) Studying two-cent stamp which bears Washington's picture

(5) Discussing the following questions:

(a) Is George Washington living today?

(b) Was George Washington kind?

(c) Did George Washington have any children? 
(6) Discussing the pictures of Washington's home and wife.

(7) Discussing a parade in honor of Washington.

(8) Discussing plans for (short) unit on George Washington.

(9) Planning hats, sashes, flags, line of march, drums.

(10) Writing story of plans.

(II) Writing story of parade.

(12) Writing messages to mothers telling what was done.

(13) Selecting music (victrola) to march by.

(14) Measuring size of flag, length of stripes.

(15) Counting stripes and stars.

(16) Reading stories and bulletin board.

b. Thanksgiving Day

Real life experiences and interests

(I) Eating Thanksgiving dinner with grandmother.

(2) Watching mother dress chicken.

(3) Going with father to deliver basket of fruit to a siak friend.

(4) Taking basket of food to needy.

(5) Going with parents to orchard.

(6) Going to the bakery.

Related activities

(I) Making an animal booklet.

(2) Taking excursions to store, market, farm, etc.

(3) Watching the farmer milk the cow.

(4) Making cottage cheese.

(5) Churning butter.

(6) Baking gingerbread boys and girls.

Grade 2

a. Armistice Day

Real life experiences and interests 
(1) Visiting a memorial to heroes.

(2) Seeing a parade.

(3) Waving a flag.

(4) Saluting a flag.

Possible activities

(1) Participating in school program.

(2) Reading and listening to suitable poems and stories of loyalty, bravery, and the joys of peace.

b. Thanksgiving Day

Real life experienoes and interests

(1) Seeing Thanksgiving decorations in stores.

(2) Reading Thanksgiving stories.

(3) Going to church on Thanksgiving.

(4) Going to grandmother's for Thanksgiving.

(5) Eating Thanksgiving dinner.

Unit Experiences

(1) Dramatizing Indian and Pilgrim stories eg. (Red Father from Long Ago Stories, The Thanksgiving Feast)

(2) Reading other stories relating to Pilgrims for background to the play.

(3) Having a Pilgrim and Indian doll exhibit.

(4) Dramatizing the First Thanksgiving.

(5) Making an Indian village.

(6) Making a farm.

(7) Having picture show with school machine, using Pilgrim and Indian slides.

(8) Preparing a basket for a hospital or a poor family in need.

(9) Going on an excursion to a store or market.

(10) Parching corn.

(II) Discussing plans for play.

(12) Making scenery for play. 
(13) Selecting materials.

(14) Composing and extending invitations to see the play.

(15) Measuring materials used in scenery.

(16) Making and decorating scenery, materials needed for the play.

(17) Relating and retelling stories of the First Thanksgiving in the first person.

(18) Memorizing and appreciating poems relating to Thanksgiving.

(19) Giving library reports of stories and poems.

(20) Creating cross word puzzles using words relating to Thanksgiving.

(21) Creating original stories.

(22) Learning to spell and write new words.

(23) Illustrating Indian and Pilgrim Iife for room decorations and booklets.

(24) Painting dolls for papooses and dressing them in blankets.

(25) Learning new Indian songs.

(26) Appreciating and interpreting victrola records.

(27) Imitating in play periods Indian styles of standing, and sitting in postures like Indian men and women, hunting, canoeing, swimming, dancing, beating tom-toms.

(28) Playing games typical of Indian life which became popular such as, playing ball, spinning tops, rolling hoops, running races, and jumping.

c. George Washington

Real life experiences and interests

(1) Seeing pictures of Washington in magazines and newspapers.

(2) Playing soldier.

(3) Going to a Washington's Birthday party.

(4) Visiting Gity of Washington. 
School activities

(1) Patriotic parade.

(2) Assembly or room program.

Related activities

(1) Collecting pictures of Washington for a comparison of costumes and customs with those of today.

(2) Visiting a Washington statue.

(3) Making soldier hats.

(4) Drawing the flag.

(5) Drawing the flag, flying.

(6) Making illustrations of stories about Washington as a soldier.

d. Memorial Day

Real life experiences and interests

(1) Putting up the flag.

(2) Seeing a parade.

(3) Going to a cemetery.

Possible activities

(1) Iistening to poems and stories of honor and bravery.

(2) Giving peace salutes to the flag.

Grade 3

a. Columbus Day

Real life experiences and interests

(1) Playing Indian and Cowboy.

(2) Wearing Indian and Cowboy suits.

(3) Seeing pictures of Columbus.

(4) Talking about how Indians lived.

(5) Collecting pictures of ships, Indians, explorers.

(6) Reading history stories.

(7) Hearing older brother recite a poem about Columbus.

(8) Attending a Columbus program. 
Unit experiences

(1) Room program.

(2) Assembly program.

(3) Poster composition.

(4) Dramatization.

(5) Pageant.

(6) Blackboard panel decoration in colored chalk for calendar.

(7) Reading stories about Columbus.

Related activities

(I) Reading and producing stories about Columbus.

(2) Illustrating story about discovery of America.

(3) Appreciating and memorizing poems and quotations.

(4) Iistening to patriotic musio.

b. Armistice Day

Real life experiences and interests

(1) Carrying the flag in parade at school.

(2) Saluting the flag.

(3) Knowing someone who was in France during the World War \#l.

(4) Hearing the Marine Band.

(5) Visiting the Soldiers Home.

Unit experiences in school which utilize or approximate real life experiences and interests.

Possible activities

(1) Reading or listening to stories and poems of bravery, and the blessings of peace.

(2) Participating in school room program.

(3) Giving peace salute to the flag.

(4) Listening to patriotic program over the radio.

(5) Taking a trip to a Memorial. 


\section{c. Thanksgiving Day}

Real life experiences and interests

(I) Seeing Thanksgiving decorations in stores and windows.

(2) Reading and hearing Indian stories and poems.

(3) Seeing pictures and articles of Pilgrims.

(4) Participating in Thanksgiving program.

(5) Feeding turkeys on grandfather's farm.

(6) Helping make pumpkin pie.

(7) Going to grandmother's for Thanksgiving.

(8) Helping to prepare Thanksgiving dinner.

(9) Going to church on Thanksgiving.

Unit experiences in school

(1) Dramatizing the First Thanksgiving.

(2) Studying about Thanksgiving in early Kansas City.

(3) Making booklet or poster composition.

(4) Having a room or assembly program.

Related experiences

(I) Reading, hearing or telling stories about Pilgrims and Indians.

(2) Memorizing poems.

(3) Enjoying slides about Pilgrims and Indian life.

(4) Parching and popping corn.

(5) Preparing basket for needy family.

(6) Making and painting small clay bowls of fruit, as favors at Thanksgiving dinner or school party.

(7) Making November calendar panel decorations in colored chalk on blackboard. 
d. Lincoln's Birthday

Real life experiences and interests

(1) Seeing street decorated with flags

(2) Seeing pictures and articles about Lincoln in newspapers and Magazines.

(3) Hearing people talk about Lincoln.

(4) Hearing about"honest Abe".

(5) Reading story about Lincoln's dog.

(6) Making a log cabin.

(7) Seeing statue of Lincoln.

Unit experiences

(I) Booklet

(2) Dramatization

(3) Log cabin

Related activities

(1) Reading history stories about Lincoln's boyhood and life as President.

(2) Memorizing patriotic poems.

(3) Illustrating Iincoln's boyhood.

(4) Constructing furniture for log cabin.

e. George Washington' s Birthday

Real life experiences and interests

(1) Seeing pictures of Washingt on in magazines and newspapers.

(2) Hearing people talk about our first President.

(3) Playing soldier.

(4) Participating in patriotic program.

(5) Giving a costume party on Washington's Birthday.

(6) Hearing friends tell of their visit to Washington D.C.

(7) Seeing post cards of the White House and large buildings in Washington. 
Unit experiences

(1) Having a patriotic program in room or auditorium.

(2) Giving radio program.

(3) Having patriotic parade.

(4) Dramatizing First Flag.

Related experiences

(1) Listening to and reading stories of Washington's life.

(2) Collecting historical pictures.

(3) Comparing colonial costumes and customs with those of today.

(4) Visiting a Washington statue.

(5) Reading a story about Betsy Ross and the first flag.

(6) Learning the meaning of the flag, its colors and its symbol.

(7) Learning correct use of the flag to honor it.

f. Memorial Day

Real life experiences and interests

(1) Seeing homes and streets decorated with flags.

(2) Putting up flag at home.

(3) Seeing parade.

(4) Hearing patriotic band in parade.

(5) Visiting the cemetery.

Possible activities

(1) Hearing, reading or telling stories about our soldiers and sailors.

(2) Appreciating poems and quotations about Memorial Day.

(3) Giving peace salute to the flag.

3. Los Angeles, California, 1924

(Grades - Kindergarten, First and Second.)

Suggested activities

Grade 1

Making models suggestive of the holiday. 
Grade 2

a. Columbus Day - called Discovery Day

(1) Discovering Italy, Spain and America on the map.

(2) Telling the story of Columbus including his early life, trips and adventures.

(3) Drawing pictures to illustrate the life of Columbus.

(4) Making a sand table representation with Spain at one end and America at the other showing Indians, tepees, canoes and pine forests.

(5) Dramatizing discoveries of Columbus.

b. Memorial Day

(1) Building a soldier's camp.

(2) Discussing a real soldier's camp. (a) contents

(b) duties of soldiers

4. Minneapolis, Minnesota,

Public School Course of Study in English

Composition, Correct Usage and Spelling, 1935.

Kindergarten, Grades $1-6$. Review made of Grades 1 - 3 only.

In relation to patriotic holidays the following statement is made: "The observance of holidays offers opportunity for original dramatizations, poems, stories and pageants if teachers will develop them with the pupils instead of using only 
those found in books".

No other suggestions for activities

for the celebration of patriotic

holidays were made.

5. St. Louis, Missouri, 1926.

St. Louis Social Studies Course of Study

Grades Kindergarten, Grades 1 - 6 .

Review made of Grades 1 - 3 only.

Grade 1

a. Flag Day

(1) Having flag drills.

(2) Having the flag salute.

(3) Singing songs.

(4) Looking at pictures.

(5) Learning memory verses.

(6) Dramatizing the story of Betsy Ross.

(7) Having patriotic exercise: morning salute to the flag, repeating the pledge; singing the national anthem or other patriotic songs in assembly meetings when the flag is displayed.

(8) Having flag drills or parades for special days.

(9) Listening to records of patriotic songs or to other music.

b. Columbus Day

(1) Having informal talks.

(2) Iistening to simple stories.

(3) Looking at pictures.

c. Thanksgiving Day

(1) Having informal talks. 
(2) Looking at pictures.

(3) Listening to stories, bringing out just the more outstanding historical facts, such as the following:

(a) The voyage of the Mayflower

(b) Conditions of life in the new country.

(c) The friendly attitude of the Indians.

(d) The first winter. (e) The Thanksgiving Feast.

(4) Bringing offerings for the less fortunate.

(5) Dramatizing.

(6) Making posters.

(7) Making booklets.

(8) Making charts.

d. Decoration Day

(1) Having flag drills.

(2) Having parades.

(3) Singing songs.

(4) Listening to stories.

(5) Having informal talks.

(6) Bringing in newspaper clippings pertaining to Decoration Day.

(7) Looking at pictures.

e. Armistice Day

(1) Use same type activities as suggested for Decoration Day.

f. Washington's Birthaay

(1) Having an assembly program.

(2) Dramatizing some little stories of his life.

(3) Having a flag drill.

(4) Singing a special song.

(5) Reciting verses.

(6) Having a parade.

(7) Making booklets.

(8) Making posters.

(9) Making costumes for dramatizing.

(10) Making charts.

(11) Listening to stories. 
g. Iincoln's Birthday

(1) Having informal talks.

(2) Iistening to stories.

(3) Looking at pictures.

(4) Bringing information from home.

(5) Making booklets.

(6) Reading stories from board.

(7) Making charts.

Grade 2

a. Columbus Day

(I) Talking about Columbus and what he did.

(2) Looking at pictures.

(3) Listening to stories about Columbus.

(4) Making a poster of Columbus coming to America.

(5) Modeling clay ships.

(6) Drawing ships.

(7) Copying pictures.

(8) Drawing a picture.

(9) Learning songs about our nation.

(10) Learning verses about Columbus.

(11) Giving a Columbus Day entertainment.

(12) Dramatization of the story of Columbus.

(13) The telling of stories about Columbus.

(14) The giving of favors.

b. Armistice Day

(1) Talking about Armistice Day.

(2) Listening to stories.

(3) Learning verses about peace.

(4) Listening to poems about peace.

(5) Learning songs.

c. Thanksgiving Day

(1) Talking about Thanksgiving Day and what it means.

(2) Studying about the Pilgrims.

(3) Listening to stories about Thanksgiving Day and of the Pilgrims. 
(4) Learning verses and songs about Thanksgiving Day, the Pilgrims, the Dutch, and the Indians,

(5) Collecting and looking at pictures.

(6) Making charts and booklets.

(7) Making a community poster.

(8) Drawing pictures.

(9) Making sand table construction.

(10) Dressing dolls in Pilgrim, Dutch or Indian clothes.

(11) Looking at lantern slides.

(12) Dramatizing the story of the Pilgrims.

(13) Dramatizing the story of a present day Thanksgiving.

(14) Giving a party.

d. Lincoln's Birthday

(1) Talking about Lincoln's boyhood and about what Iincoln did for our country.

(2) Listening to stories and poems.

(3) Retelling and writing stories.

(4) Learning verses about Lincoln.

(5) Learning songs about our nation.

(6) Looking at pictures.

(7) Making a poster.

(8) Drawing pictures.

(9) Constructing a log cabin.

(10) Dramatizing.

(II) Giving a community celebration.

e. Washington's Birthday

(1) Studying about Washington's boyhood and about what he did for our country.

(2) Listening to stories and poems.

(3) Retelling and writing stories.

(4) Learning verses about Washington.

(5) Learning songs about our nation.

(6) Looking at pictures of Washington.

(7) Making a poster.

(8) Drawing a picture.

(9) Constructing a log cabin, a hatchet, etc.

(10) Giving a community celebration. 
f. Memorial Day

(1) Studying about Memorial Day.

(2) Listening to stories and poems.

(3) Retelling stories.

(4) Learning verses about Memorial Day.

(5) Collecting and looking at pictures about Memorial Day.

(6) Making a chart or booklet.

(7) Making a poster of Memorial Day parade.

(8) Drawing pictures.

(9) Saluting the flag.

g. Flas Day

(1) Learning songs about our flag.

(2) Marching.

(3) Talking about Flag Day.

(4) Listening to stories about our flag.

(5) Learning songs about our flag.

(6) Learning verses.

(7) Making a poster showing the development of the flag.

(8) Saluting the flag.

Grade 3

a. Columbus Day

(1) Telling or reading the story of Columbus' ships and voyages.

(2) Talking about his great discovery.

(3) Constructing ships.

(4) Drawing pictures.

(5) Singing songs.

(6) Dramatizing.

(7) Collecting pictures.

(8) Modeling ships.

b. Armistice Day

(1) Discussing the meaning and significance of Armistice Day.

(2) Discussing ways better than war to settle difficulties. 
c. Thanksgiving Day

(1) Talking, reading or telling about the Pilgrims.

(2) Constructing ships, homes, etc.

(3) Giving a play.

(4) Singing songs.

(5) Drawing pictures.

(6) Discussing our Thanksgiving Day

(7) Discuss the following topics:

(a) President's Proclamation

(b) How we celebrate

(c) How we may show thanks

d. Lincoln's Birthday

(1) Discussing the life of Lincoln

(2) Telling or reading about his life.

(3) Singing songs.

(4) Drawing pictures.

(5) Constructing a log cabin.

(6) Collecting pictures.

e. Washington's Birthday

(I) Discussing the life of Washington.

(2) Telling or reading stories about Washington.

(3) Discussing the following:

(a) Boyhood of Washington

(b) Surveyor and farmer

(c) Home at lit. Vernon

(d) Martha Washington

(e) Iife as a soldier.

(f) Life as President

(g) Great qualities

f. Memorial Day

(1) Discussing the meaning of $\mathrm{Me}-$ morlal Day.

(2) Singing patriotic songs.

(3) Drawing pictures.

(4) Reciting memory verses.

(5) Holding exercises.

g. Flag Day

(1) Discussing the meaning of Flag Day.

(2) Saluting the flag.

(3) Singing patriotic songs.

(4) Drawing pictures.

(5) Telling the story of the first flag. 
B In the Central States

1. Cincinnati, Ohio 1926

Tentative Course of Study in Language

Expression for the Kindergarten, Primary

Grades.

Suggested activities

(I) Conversing, using holidays as topies for discussion.

2. Detroit Public Schools 1925

Course of Study in English Grades 1 - 6

(Grades 1 - 3 used only)

Suggested material for special days in-

cluding patriotic holidays listed by grades.

Patriotic holidays included are:

a. Armistice Day

b. Columbus Day

c. Flag Day

d. Lincoln's Birthday

e. Labor Day

f. Memorial Day

g. Washington's Birthday

This material inlcuded stories and poems.

Suggested activities

(1) Making a sand table for Thanksgiving

(2) Discussing Lincoln and some of his pictures-developing character study.

(3) Writing stories.

(4) Appreciating poems. 
C In the Southern States

1. Fort Worth, Texas, 1935

Language Arts - A Tentative Course of Study

Suggested patriotic holidays are:

a. Armistice Day

b. Washington's Birthday

c. Thanksgiving

Grade 1

Suggested activities

(I) Telling stories

(2) Giving announcements, explanations and directions

(3) Asking and answering questions.

(4) Dramatizing stories of holidays.

(5) Writing letters.

(6) Keeping records.

(7) Copying.

(8) Writing stories, poems and plays relating to the celebration of holidays.

Grade 2

Suggested activities

(I) Discussing special days

(2) Giving reports and talks

(3) Having conferences and meetings.

(4) Planning for parties or other ways of celebrating special days.

(5) Telling and retelling stories relating to Columbus, Armistice Day.

(6) Listening to stories about Lincoln.

(7) Keeping record of holidays and important events. 
Grade 3

Suggested activities

(1) Giving reports of stories read and information collected.

(2) Having conversations and discussions relative to patriotic holiday celebration.

(3) Telling stories.

(4) Making announcements, explanations and directions.

(5) Dramatizing stories.

(6) Writing stories, plays and poems.

2. Louisville, Kentucky.

A preliminary Course of Study in English for Kindergarten - Primary Grades, 1940. Grade 1

Suggested activities

(I) Conversing.

(2) Letter writing.

(3) Reporting of a special day to an absent pupil.

(4) Writing and using capital letters for holidays, etc.

Grade 2

Suggested activities

(1) Conversing on the topics relating to patriotic holidays.

(2) Writing an invitation for special day program.

(3) Discussing and reaching decisions.

(4) Planning programs.

(5) Reading for information.

(6) Reading and telling stories.

(7) Dramatizing

(8) Singing and discussing songs suitable for special day programs. 
Grade 3

Suggested activities

(1) Conversing - discussing

(2) Telling and reading stories

(3) Writing original stories

(4) Writing words for songs

(5) Outlining for programs.

(6) Writing plays.

(7) Writing letters of invitation.

(8) Writing articles for school paper.

(9) Dramatizing plays written by the class.

(10) Singing and discussing songs suitable for special day programs.

3. Raleigh, North Carolina, 1928-1931

Grade 1

Suggested activities - None

Grades 2 and 31928

Suggested activities

a. Thanksgiving

(1) Having a party to develop ability to work together.

4. Raleigh, North Carolina, 1936

Social Studies Course of Study

Unit, "A Play City"

Suggested activities

(1) Studying American Flag - the first flag and the flag of today. 
D In the Eastern States

1. Baltimore, Maryland. 1937

County Courses of Study in English, 1937

Grades 1, 2 and 3.

Grades 1 and 2 .

Suggested activities - None

Grade 3

Suggested activities

(1) Writing names of holidays with capitals.

(2) Summarizing in a few sentences class discussion of reasons for celebrating special holidays.

(3) Copying correctly titles of books having patriotic holiday stories.

(4) Making a collection of flags from other lands.

List of material appropriate for special

days (by grades) to be read by pupils is

given. The patriotic holiday material

listed in the bibliography is:

Grade 1

a. Thanksgiving Stories.

Grade 2

8. Thanksgiving stories

b. Abraham Lincoln stories and poems.

c. Columbus Day song.

c. Thanksgiving song. 


$$
\begin{aligned}
& \text { Grade } 3 \\
& \text { Stories } \\
& \text { a. Washington } \\
& \text { b. Columbus } \\
& \text { c. Thanksgiving }
\end{aligned}
$$

Poems

a. Armistice Day

b. Flag Day

c. Memorial Day

d. Lincoln's Birthóay

From the above detailed report of the survey, it will be seen that, out of twenty-one courses of study, there are nine which suggest no activities connected with our patriotic holidays. No definite reason for the omission of such suggestions could be found, but it seems logical to conclude that the causes lie in the history of our educational system. We know that in the early part of the Twentieth Century, child activities and child experiences received Iittle attention in our schools. Naturally, the celebration of patriotic holidays, like all other vital experiences of the child, had no place in the curriculum. Later, when the activity program was 
introduced, the pendulum seemed to swing to the other extreme. Such great stress was placed upon the activity of everyday life that the special days and their observance were placed in the remote background or entirely omitted. To those who so thoroughly emphasized the everyday experiences of the child, we might justly say, "These things ye ought to have done and not to leave the other undone".

Out of the twelve courses of study which suggest patriotic holiday activities, there are only four which include in their lists the reading, by the children, of holiday stories and poems. The Social Studies Course of Study of St.Iouis, Missouri, 1926, includes in its list of activities for the first grade the reading of Iincoln Birthday stories from the board. Curriculum Bulletin No. 8, Kansas City Public Schools, Kansas City, Missouri, 1930, suggests reading by the children as a patriotic holiday activity in grades one, two and three. Among the first grade activities for Washington's Birthday, "reading picture section in the paper" is suggested. Armistice Day activities listed for second and third grades include "reading and listening to suitable poems and stories of loyalty, bravery, and the joys of peace". This course

1 Matthew 23:23 
of study also suggests reading and hearing stories about Columbus, reading Indian stories and poems, reading stories about Pilgrims and Indians and reading about Lincoln's boyhood. The third course of study which includes reading among the suggested patriotic holiday activities is that of Louisville, Kentucky. In A Preliminary Course of Study in English for Kindergarten-Pximary Grades, 1940, we find among "Suggested Activities" for the second grade "reading for information" and "reading and telling stories". The Baltimore County Course of Study in English, 1937, for Grades $1, \underline{2}$ and $\underline{3}$ gives a list of materials appropriate for special days to be read by the pupils. This list is arranged according to grades.

Why is it that, out of twenty-one of our present day courses of study, there are only four which even mention the reading of patriotic holiday stories and poems among the activities which are to be engaged in by the children of the primary grades? Why is it that, of these four, only one gives a list of holiday materials which are appropriate for use in carrying out this activity?

These questions cannot be answered fully because of the failure of superintendents and supervisors to respond to the questionnaires sent out by the writer. 
Below are some of the responses of the superintendents and supervisors to the questions relating to the lack of suggestions for patriotic holiday activities for grades one, two and three in their courses of study. Ruth Henderson writes:

"Activities which develop patriotism should not be concentrated on certain days, but the democratic way of working with youngsters and of youngsters working with each other should permeate the life of the school during all days of the year. If you will examine our materials you will find that we do have activities which could be appropriately engaged in on patriotic holidays, but they are not separated into one category of patriotic holidays but scattered throughout the materials."

A survey of the Virginia State Course of Study by the writer of this thesis showed no patriotic holiday activity suggestions for grades one, two and three. The writer of this thesis believes that children are interested in reading stories that are timely. For instance, during the days immediately preceding Columbus Day they are interested in reading stories about Columbus. Therefore, if in this course of study the patriotic holiday reading material had been arranged "in one category", the course of study would have been more helpful to teachers than it now is.

1

Supervisor of Elementary Education, State Board of Education, Richmond, Virginia. 
It is the writer's opinion that in the teaching of patriotism, a real essential is "atmosphere". An appeal must be made to the heart, to the spirit and to the emotions as well as to the intellect. By giving emphasis to our patriotic holicays, the "atmosphere" and appeals can readily be made toward a higher degree of patriotic citizenship; Miss Henderson says,

We do have activities which could be appropriately engaged in on patriotic holidays, but they are not separated into one category of patriotic holidays but scattered throughout the materials."

\section{2}

Prudence Cutright answers the question with the

following response:

"There are two reasons: (for no mention of patriotic holiday stories and poems in the course of study in reading) (1) the course of study is not devoted to the listing of materials, but rather to suggestions on techniques and teaching; (2) I consider the observance of patriotic holidays neither the exclusive function of a reading program nor even a major function, but rather the responsibility of the social studies period. If a school has a good social studies program it should contain considerable attention to patriotic holidays and observance. our new course contains a quantity of such material."

1

Supervisor of Elementary Education, State Board of Education, Richmond, Virginia.

2

Assistant Superintendent, Minneapolis Public Schools, Minneapolis, Minnesota. 
This new course of study for the Minneapolis schools was not available when the writer of this thesis was making the survey of the courses of study. It is of significance that Minneapolis educators felt the need for patriotic holiday activities, and has supplied them, according to Miss Cutright's response.

other superintendents and supervisors have responded that they are working under such heavy pressure in connection with war activities in the schools that they did not feel free to take the time necessary for providing this information.

It is desired by the writer that in the near future, the authors of new courses of study will follow the example of the Minneapolis educators and will feel the need for patriotic holiday activities which will inevitably require patriotic holiday reading materials as a background.

The writer concludes on the basis of her limited number of responses that the causes for the failure on the part of writers of courses of study to include patriotic holiday activities lie in the history of our educational system.

A third observation which the survey of these courses of study causes us to make is this: out of the twentyone courses studied, there are eight which emphasize 
discussion or conversation of the desirable activities in connection with patriotic holidays. These suggestions are in harmony with the point of view of McKee who says:

"An introspective analysis of the particularized composition situations of life shows that activities in which oral expression is used are much more common and frequent in occurrence than those activities which involve writing. This judgment is supported by objective data collected in such investigations as those by Searson, clapp, Baker and Johnson. Obviously, this means that it is more important for the pupil to learn to express himself well in oral form than in written form. Until data are made available on the relative learning difficulty of oral and written composition it is wise to assume that that the sohool must spend most of the available time and energy on oral composition. Many modern schools are now doing this. Usually all the composition in the kindergarten and first grade is oral. In the second and third grades approximately fourfifths of the time should be spent on oral composition, and one-fifth on written composition."

The writers of these suggestions concerning conversation and discussion as a part of the patriotic holiday celebration have recognized the fact that conversational ability is one of the most important to be acquired by children of these grades.

1

Paul McKee, Language in the Elementary School, p 166 
They would agree, I am sure, that "the most important element in good conversation is to have something worthwhile to talk about". If children are to talk intelligently about these patriotic holidays, one of the ways of securing a background which will give them "something to talk about" is by reading many bits of information, stories and poems, from which they will obtain knowledge of and imbibe the spirit of the holiday to be discussed. "Vague and indefinite concepts on the part of the speaker, writer, listener, or reader make for misunderstanding". Therefore, the material which the children are to read and later to discuss, to retell or rewrite should be simple enough for them to read and understand without great difficulty. Shall we not attempt to provide material which will clarify concepts and, by giving the children something to talk about, aid them in developing conversational ability?

The Need for Such Material Felt by the Teachers. In order to find out whether teachers of grades one, two and three feel a need for patriotic holiday reading material a questionnaire was sent out to the elementary teachers of the Louisville Public Schools, to

1

Louisville Course of Study, A Preliminary Course of Study in ㅍglish. $p 12$.

2 Ibid., p 12. 3 See Appendix 
a sampling of elementary teachers of other sections of Kentucky outside of Louisville, and to a small number of primary teachers in four states.

The questionnaire was composed of three parts. The first was with reference to whether a need is felt for patriotic holiday reading material. The second part listed the patriotic holidays which occur during the school calendar year and in the order of their occurence beginning in september. These holidays are: Labor Day, Columbus Day, Armistice Day, Thanksgiving Day, Abraham Lincoln's Birthday, George Washington's Birthday, Memorial Day and Flag Day. Holidays were checked where a need was felt for material. The last part of the questionnaire concerned the need felt by the primary teachers for an anthology of patriotic holiday stories.

A larger number of questionnaires was sent to the Louisville primary teachers because the writer wanted the major picture to be from Louisville. Sending out the questionnaires to a sampling of primary teachers in Kentucky and other states fulfilled the writer's desires to see if these teachers agree with Louisville teachers.

Table II gives the results of survey of the need 
for patriotic holiday reading material as felt by 239 primary teachers of the Louisville Public Schools. Two hundred and fifty questionnaires were sent out and 239 replies were received. This was a 95 percent response to the questionnaire. The total of the teachers of grades one, two and three showed that 94.1 percent need patriotic holiday reading material. The highest percentage was in grade two with 98.7 percent. The lowest was in grade one with 86 percent.

According to Louisville primary teachers the holiday for which they, as a total group, feel the greatest need for material is Columbus Day. Seventy-three and seven tenths percent expressed the desire for material for that day. Labor Day is the holiday for which the total group of teachers feel the least amount of need of material. This percentage was in accordance with a previous assumption, since Labor Day does not always fall within the school calendar in Louisville.

Memorial Day is the holiday for which 87.6 percent of the third grade teachers feel the greatest need of material. Columbus Day is the holiday for which 81 percent of the second grade teachars and 68.7 percent of first grade teachers feel the greatest need of material. 
It is interesting to note that the only two holidays in the second grade for which less than 64 percent of the teachers felt a need of patriotic reading material are Labor Day and Thanksgiving Day. The writer has given her opinion as to her belief for a lack of need for Labor Day. According to Table I "The Survey of Forty-four Present Day Textbooks for Patriotic Holiday Material", Thanksgiving was the holiday with the largest amount of stories. It is the writer's opinion that this may be the reason for only 48.1 percent of the second grade teachers feeling a need for material for Thanksgiving Day.

One hundred percent of the first and third grade teachers replying expressed a need for an anthology of patriotic holiday stories for use in grades one, two and three. In grade two 98.8 percent of all Louisville primary teachers feel a similar need.

It is of significance that 94.1 percent of the 239 Louisville primary teachers who responded to the questionnaire feel a need for patriotic holiday reading material and that 99.5 percent of this same group feel a need for an anthology. Also, it is well to note that with the exception of Labor Day that (as a primary group) more than 54.4 percent of the Louisville 
primary teachers who responded to the questionnaire feel a need for reading material for every patriotic holiday during the school year. The results of the responses from the questionnaire are summarized in Table II. 


\section{Table II}

A Survey of Needs for Patriotic Holiday Reading Material by 239 Primary Teachers of the Louisville Public Schools

Question

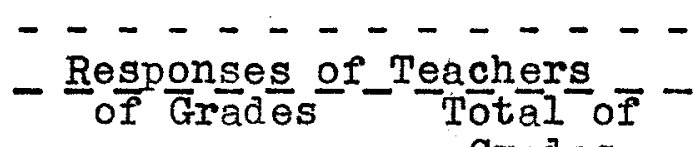

$\begin{array}{llll}2 & 2 & 3 & \text { Grades }\end{array}$

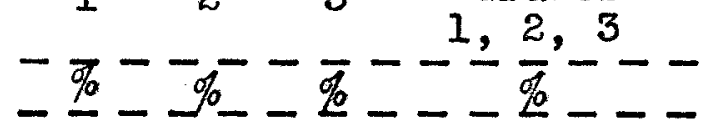

Need for Material _ - - - $66.98 .798 .6 \ldots-94.1$

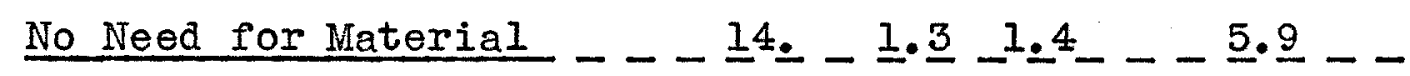
Holidays (Material needed)

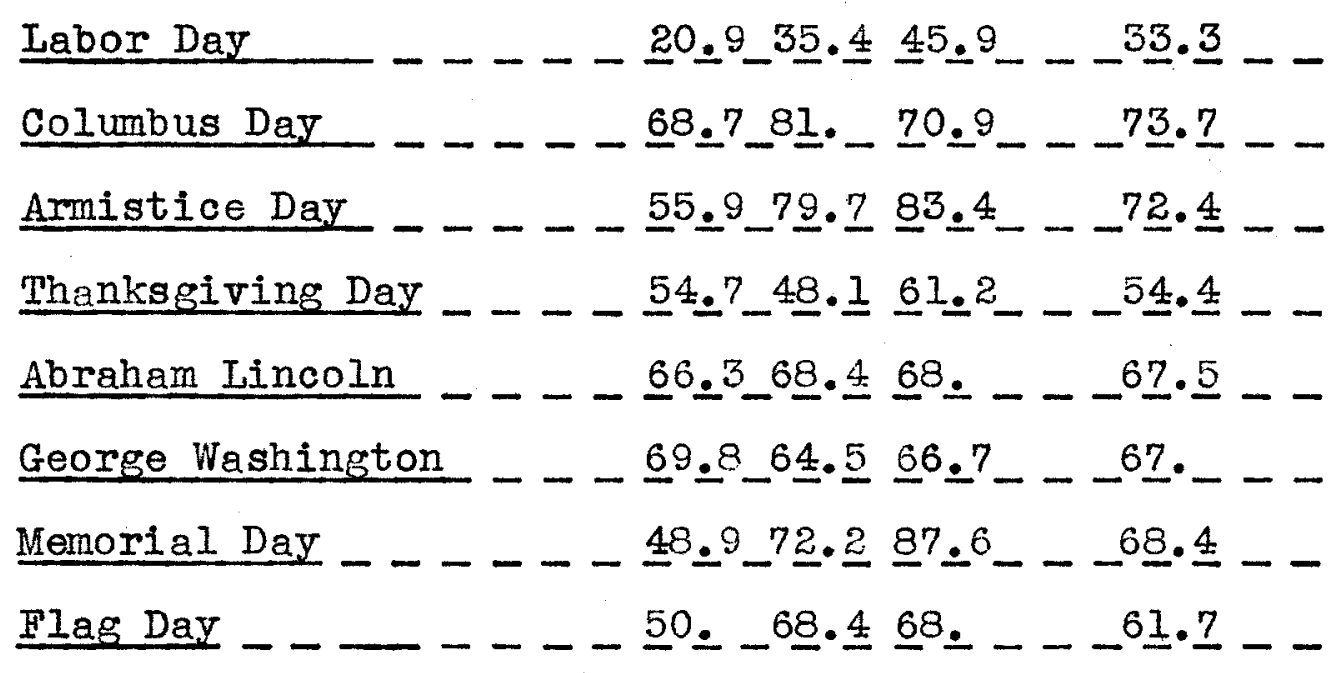

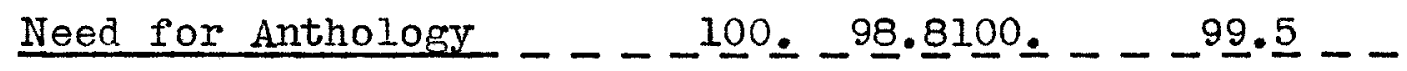
No Need for Anthology $-\ldots-.0^{0}-2 \cdot 2$

Questionnaires Sent out - 250

Replies to Questionnaires - 239

Table II shows that 94 percent of the primary teachers of Louisville need this material. 
Table III is a survey of needs for patriotic holiday reading material of 268 primary teachers including Louisville. Thirty questionnaires were sent to primary teachers of Kentucky in addition to the 250 sent to Louisville teachers. A total of 268 replies were received. Table III was made to see what effect these additional replies would have on the major picture, Louisville.

The total responses from the primary teachers of Kentucky show that 92.9 percent of the 268 teachers feel a need for patriotic holiday material. This was only 1.2 percent less than the 94.1 percent Louisville primary teachers who expressed a need as shown in Table II. Ninety-four and one-tenth percent represented. the opinions of 249 teachers.

There is only a slight variation in the percentage in Table II and Table III.

An increased percentage is show in grades one, two and three as needing material for Labor Day. It is the opinion of the writer that most county schools open prior to September 1 and thus Labor Day is included in their school year. There is also a noted 6 percent increase in the need of material for Columbus Day in grade three.

The results of the responses of 268 primary teachers in the state of Kentucky are summarized in Table III. 
A Survey of Needs for Patriotic Holiday Reading Material by 268 Primary Teachers in the State of Kentucky Including Louisville

\section{Question}

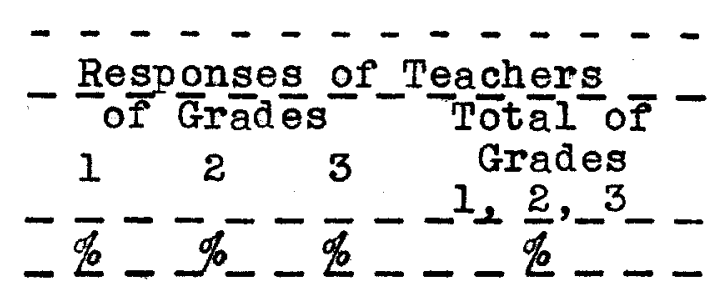

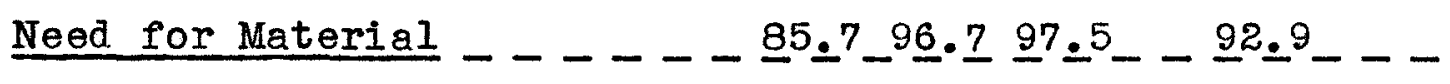

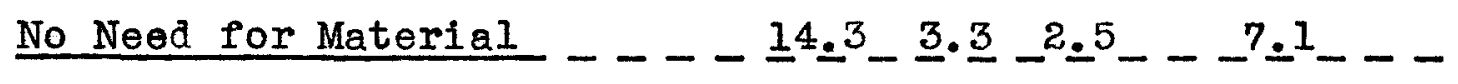
Holidays (Material needed)

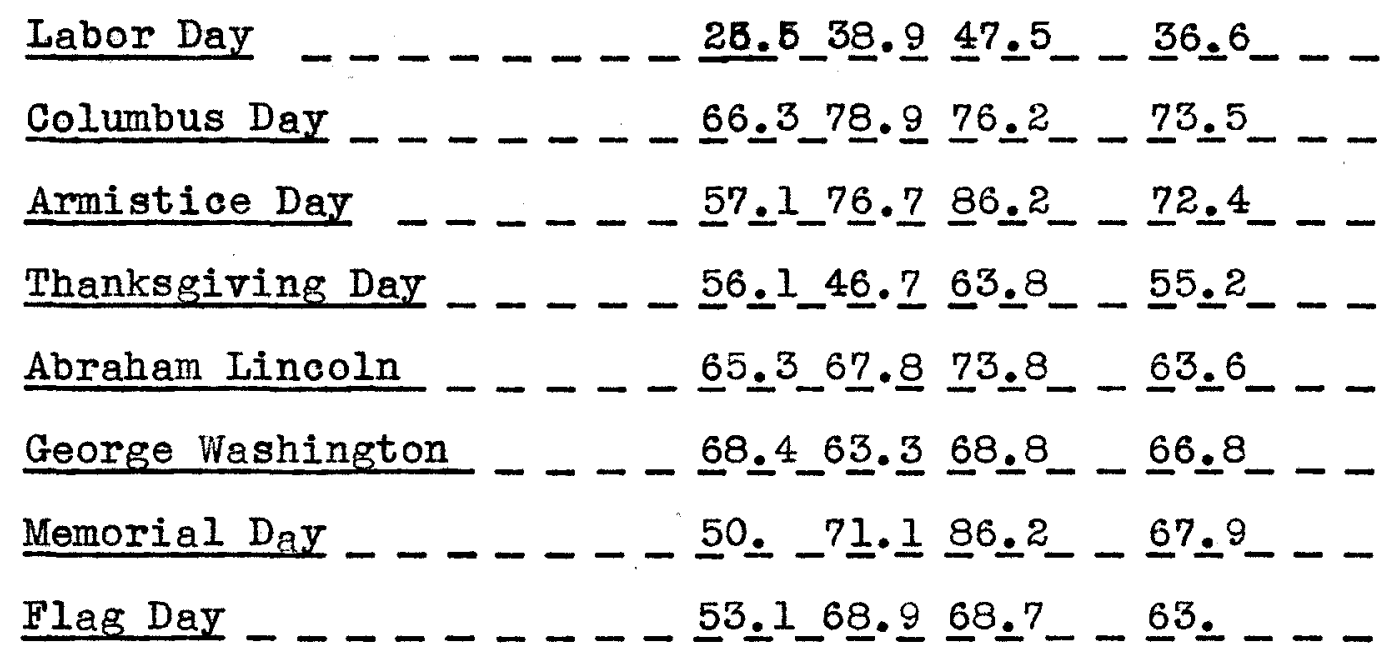

Need for Anthology $-\ldots-100.998100 .099 .7 \ldots$

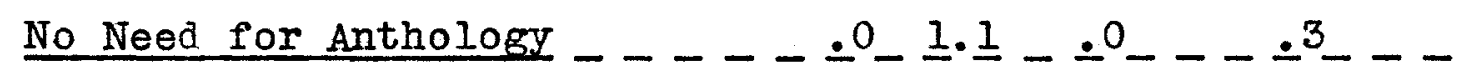
Questionnaires Sent Out - 280 Replies to Questionnaires - 268 
Table IV is the summary of a survey of the needs for patriotic holiday reading material by 34 primary teachers of ten schools from the states of Georgia, Illinois, Ohio, Kentucky and Virginia. Louisville is not included in Kentucky's report. This, too, is an effort to see how a sampling of surrounding states would compare with the major picture, Louisville.

The results of the responses from the questionnaire are surmarized in Table IV. 
Table IV

A Survey of Needs for Patriotic Holiday Reading Material by 34 Primary Teachers of Ten Schools from the States of Georgia, Illinois, Kentucky, Ohio and Virginia

(Louisville is not included in Kentucky)

Question
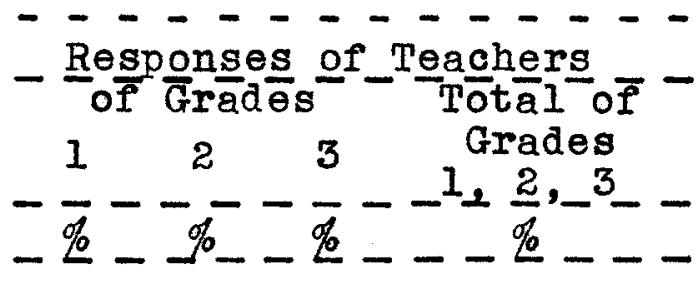

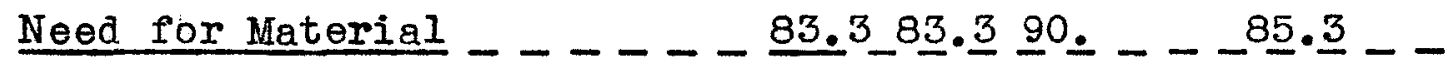

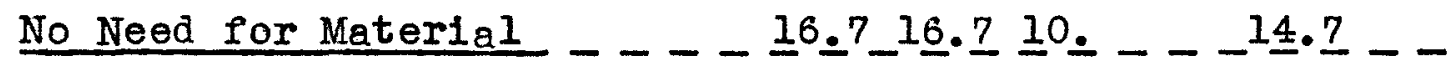
Holidays (Material needed)

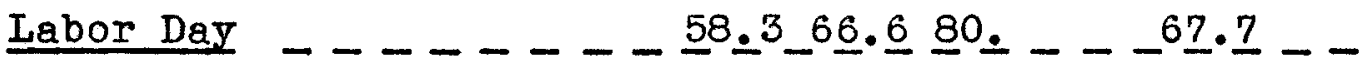

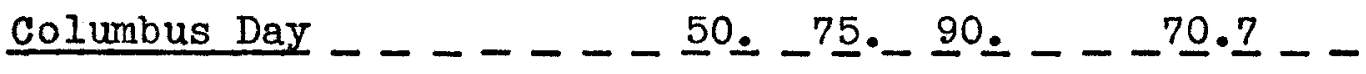

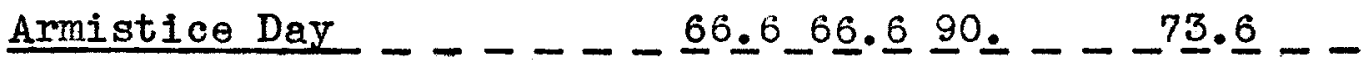

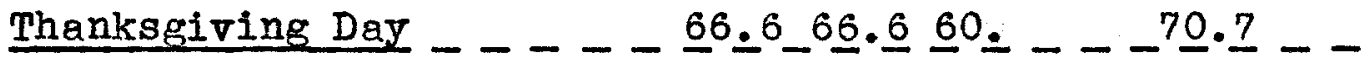

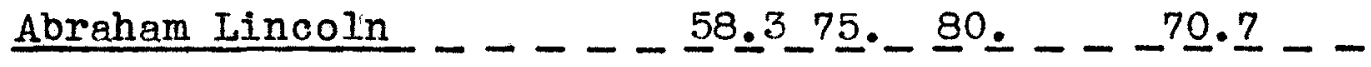

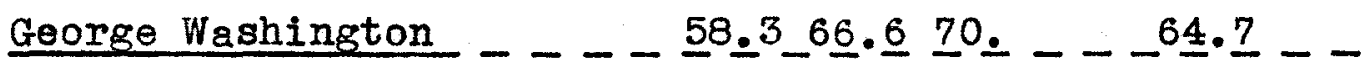

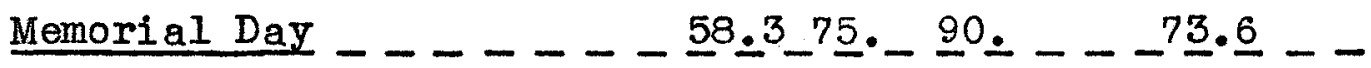

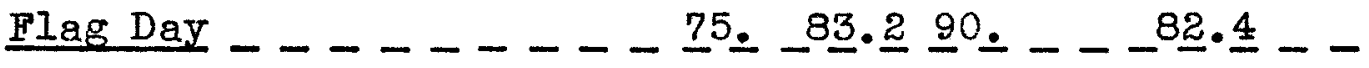

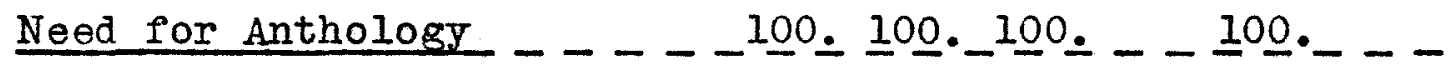

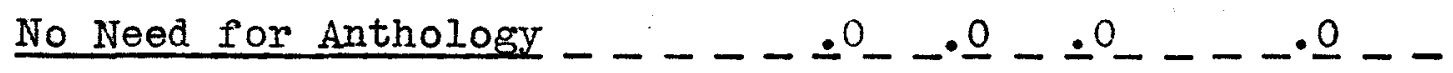
Questionnaires Sent out - 50 Replies to Questionnaires - 34

According to Table IV, 85 percent of the teachers represented in the survey of ten schools in Ohio, Illinois, Georgia, Kentucky, Virginia need this material. 
There is not a great variation in any of the percentages. Eighty-five and three-tenths of all the teachers feel a need for patriotic holiday reading material. This is a decrease of 7.6 percent as expressed by all primary teachers, (Table III) and a decrease of 8.8 percent as expressed by the Louisville primary teachers (Table II) who are in need of patriotic holiday reading material. This survey shows an increased percentage of teachers who need material for Labor Day. Louisville Teachers for grades one, two and three show 20 percent, 35 percent and. 45 percent respectively needing this material. The responses from the teachers from the states of Georgia, Illinois, Kentucky, Ohio and Virginia for grades one, two and three are 58 percent, 66 percent and 80 percent respectively. Again, it is the writer's opinion that this increase is due to the fact that the opening day of rost of these schools was prior to September 1 and Labor Day was thus included in the school year.

There is a 20 percent increase over the Louisville report of Table II in the number of third grade teachers needing Columbus Day stories. Fifty percent and more express the need for each patriotic holiday. Table II shows 54.4 percent of all the primary teachers needing material for Thanksgiving, while Table IV shows $E$ 
70.7 percent which is an increase of 16.3 percent. Flag Day material is needed by 61.7 percent of Louisville teachers of grades one, two and three and 82.4 percent of the teachers of the states listed in Table IV.

one hundred percent of the teachers responded positively as needing an anthology of patriotic holiday stories.

It is the mriter's opinion that 273 responses of primary teachers, of the states of Georgia, Illinois, Ohio, Kentucky, including Louisville, and Virginia, who are in direct contact with pupils are of significance as expressing the needs for patriotic holiday material.

Summary of Table II, Table III, and Table IV. Reading material for Labor Day was needed by 35.3 percent of the teachers represented in Table II, by 36.6 percent of those represented in Table III and by 67.7 percent of those represented in Table IV.

Columbus Day reading material was needed by 73.7 percent of the teachers represented in Table II, by 73.5 percent of those represented in Table III and by 70.7 percent of those represented in Table IV.

Armistice Day reading material was needed by 72.4 percent of the teachers represented in Table II, by 72.4 percent of those represented in Table III and by 73.6 percent of those represented in Table IV. 
Thanksgiving Day reading material was needed by 54.4 percent of the teachers represented in Table II, by 55.2 percent of those represented in Table III and by 70 percent of those represented in Table IV.

Reading material for Abraham Lincoln's Birthday was needed by 67.5 percent of the teachers represented in Table II, by 68.6 percent of those represented in Table III and by 70.7 percent of those represented in Table IV. Reading material for George Washington's Birthday was needed by 67 percent of the teachers represented in Table II, by 66.8 percent of those represented in Table III and by 64.7 of those represented in Table IV.

Reading material for Memorial Day was needed by 68.4 percent of the teachers represented in Table II, by 67.9 percent of those represented in Table III and by 73.6 per cent of those represented in Table IV.

Reading material for Flag Day was needed by 61.7 per cent of the teachers represented in Table II, by 63 per cent of those represented in Table III and by 82.4 per cent of those represented in Table IV. 
In conclusion, is it desirable to use patriotic holiday reading material in grades one, two and three? Section one of this chapter shows, "The Desirability of Such Material for these Grades". The unlimited possibilities for influencing the lives of pupils in the classroom through the celebration of patriotic holidays; the carry-over value for the other remaining days of the year; the opportunities afforded by the patriotic holidays for special emphasis in a year round program for developing good citizens; the teaching of citizenship by establishing in the hearts of youth a love for the great men and women who have dreamed and worked and sacrificed to build our Republic are of significance. Unless one is informed, he cannot truly appreciate those sacrifices of his ancestors and the responsibility that is his as a citizen. Patriotic holiday reading material is one of the more attractive and interesting means of providing this information. The reading of such material should provoke thought, expression, understanding, and broader conception of patriotism.

Is there a dearth of patriotic holiday reading material for grades one, two and three? Section two of this chapter, "The Dearth of Such Material" proves that in our lower grades there is a scarcity of this patriotic holi- 
day reading naterial in our present day textbooks. Out of forty-four present day textbooks containing two thousand seventy-one stories there are only thirty-three related to patriotic holidays.

Do the courses of study fail to make use of patriotic holiday reading material for grades one, two and three? Section three of this chapter shows in "The Failure of Courses of Study to Make Use of Such Material" that nine out of twenty-one present day courses of study make no mention of patriotism; that of the remaining twelve, only four list reading among the patriotic holiday activities; and that only one of these includes a bibliography of available patriotic holiday reading material.

Is there a need for patriotic holiday reading material felt by the primary teachers? section four of this chapter discusses "The Need for Such Material Felt by the Teachers". It proves that according to a survey,

1. of Louisville's Public School System that at least 94 percent of the primary teachers need patriotic holiday reading material.

2. of 268 primary teachers in the state of Kentucky (including Louisville) that 92 percent need patriotic holicay reading raterial.

3. of ten schools from the states of Georgia, Illinois, Kentucky (excluding Louisville), Ohio and Virginia 
85 percent of the primary teachers represented in the survey need the material.

It is significant that from these surveys at least 90 percent of the primary teachers represented feel a definite need for this type of reading material. Because of these findings criteria for the selecting of patriotic holiday reading material have been set up in Chapter Three. A discussion of the meaning of Patriotism preceeds the setting up of these criteria. 


\section{Chapter III}

\section{Criteria For Selecting}

Patriotic Holiday Reading Material 
Criteria For Selecting

Patriotic Holiday Reading Material

Introduction. The selecting of suitable patriotic holiday reading material which was proven needful in Chapter II is the topic for discussion in Chapter III. Before selection can be undertaken two steps are necessary. They are: (1) the defining of patriotism and (2) the setting up of criteria for the selection of such materials. The writer has given a definition of "patriotism" which is based on her own beliefs. She has outlined how this type of patriotism is desirable from an educational point of view. In addition, she has personally discussed the value of each holiday and has set up tentative criteria for stories about each holiday. These criteria are a result of investigation and study. Forty-six superintendents and supervisors, interested in primary grades were asked by her to evaluate and to express opinions concerning the validations of the tentative criteria. Finally, criteria for the selecting of patriotic holiday reading materials for grades one, two and three are set up at the close of the chapter. 
Patriotism - what is it?

"The word "patriotism" comes to us
from the latin l and Greek 2 root
words, the former meaning ' a fellow
countryman' and the latter referring
to 'things established by forefathers'.
It is thus that we get definitions
of patriotism such as, 'love of coun-
try' and devotion to the welfare of
one's country'. Most such defini-
tions assume the inevitability of
rivalry between various tribes and
countries. But modern inventions
have reduced the world largely to
a single unit or family of human
beings. Accordingly many are think-
ing of patriotism as 'devotion to
the welfare of one's country along
lines that include the well-being
of peoples in other lands', or
'devotion to the prosperity and
progress of one's country up to
that point which does not allow
or cause disadvantage or misfor-
tune unnecessarily to the people
of another country'. 3

From an educational point of view, it is desirable:

1. to contribute toward sequential learning by giving information about our country and those men and women who have contributed to its development;

2. to inculcate respect for one's country and for the Plag that represents it;

3. to inculcate respect for other countries and for their flags;

4. to teach children to think constructively about American heroes;

2 pater
pater
Dr. H. Leo Eddleman, Louisville, Kentucky. Interview. 
5. to teach children to recognize the fact that there is yet much to be done in order to promote the welfare of our country along lines that include the well-being of peoples of other lands;

6. to contribute toward growth in concepts of honesty, bravery, loyalty, faith, hope, industry and self-reliance and consideration for others;

7. to show that these qualities are needed in promoting the continued prosperity and progress of our country;

8. to develop skill in evaluating the contributions of citizens toward the progress and prosperity of their own and of other countries.

Information, attitudes, skills and appreciations of this type can be gained through the use of reading material centered around each patriotic holiday.

Before patriotic holiday material can be chosen, criteria to be used in the selection of such material must be set up. The writer has listed below a "Tentative Criteria To Be Used In Selecting Patriotic Holiday Reading Material for Grades one, Two and Three. These criteria have been established as an outgrowth of study in child psychology, curriculum construction and as an outgrowth of eighteen years of experience as a teacher in grades one, two and three. 
Tentative Criteria To Be Used In Selecting Patriotic

Holiday Reading Material For Grades one, Two and Three.

I Columbus Day

In order to make the contribution to the character training which should lead to good citizenship, Columbus Day reading material for grades one, two and three should supply:

1. a knowledge of why we celebrate the day.

2. a knowledge of the discovery of America and of the people found here by Columbus.

3. a knowledge of the European way of life in Columbus' time.

4. a knowledge of the boyhood of Columbus.

5. an appreciation of the dangers encountered by Columbus.

6. an admiration for such qualities as persistence, determination, faith, hope, industry and self-reliance.

7. a knowledge of geography as:

a. directions

b. Location of Europe, Asia, North America and South America.

c. location of Spain, Portugal, Italy, India, China and the West Indies.

d. location of the Atlantic, Pacific and Indian Oceans.

"The fame of Columbus is not local nor

limited. It does not belong to any

single country or people. It is the

proud possession of the whole civil-

ized world. In all the transactions

of history there is no act which for 
vastness and perfomance can com-
pare with the discovery of the
continent of America, the like
of which was never done by any
man in ancient or in later times." I

The story of Columbus is a story of patient perseverance, of high endeavor and or noble resolve a story that grips and thrills. Every boy and girl who reads the story not only reads but feels it and desires to become the discoverer of a new world.

"The Columbus Day program is an
opportunity to discover the new
world into which we are merging.
Even Childhood - on this special
day - a patriotic holiday may
come to glimpse that which Iies
beyond and feel the exultation
of the sailor who cried, "Land!
Land:" 2

If this great story is linked with the celebration of Columbus Day, it should help to develop an appreciation for those qualities which made possible the discovery of our world. This appreciation should lead to the development of better American citizens.

\section{Armistice Day}

The aim of Armistice Day material is not to teach a moral story and not to preach. It is to quicken the heart, clear the mind, and exert an influence in the direction of rich daily living. Stories helping to

$I$

James Grant Wilson, "Columbus Day", Department of Public Instruction, Special Days and Their Observances, State of New Jersey, p.52 2 Ibid., p.35 
carry out this aim should be available to be read by children of grades one, two and three. They should supply:

1. a knowledge of why we celebrate the day.

2. an understanding of the blessings of universal peace, beginning with the home and community.

3. a feeling of respect for soldiers in uniform.

4. a feeling of respect and honor for those who have fought for our country.

5. a personal application of the principles of peace and harmony.

6. a deeper appreciation of democratic way of life and democratic institutions.

Patriotism consists not in waving the flag, but in striving so that our country shall be righteous as well as strong. Celebration of Armistice Day consists not only in setting up flags to be waved, but in constantly being reminded of the heroes and the principles of character for which the red, white and blue wave. The celebration of Armistice Day alone is not sufficient, but there must be a perpatual desire for peace and a re-emphasis upon the principles which are the foundation of a peace loving people. Centering activities of Armistice Day celebration, around ideas of service to one's country will be fostering the growth of a definite attribute of good citizenship. 


\section{Thanksgiving Day}

Thanksgiving reading materials should supply:

1. a knowledge of the way the Pilgrims celebrated the First Thanksgiving Day as compared with our Thanksgiving celebration.

2. a knowledge of the loyalty to religious faith possessed by the Pilgrims.

3. a knowledge of the courage, sense of gratitude, endurance, industry, self-reliance possessed by the Pilgrims.

4. a knowledge of reasons for celebrating the First Thanksgiving Day as compared with our own reasons for celebrating Thanksgiving.

5. a feeling of thankfulness, for the comforts, opportunities and pleasures of home and community.

6. an opportunity to enjoy sharing benefits with others.

7. a sense of the need of storing supplies for winter's use.

8. a knowledge of the reasons why the Pilgrims left their homes and came to America.

9. a knowledge of the principles upon which our country was founded.

Among our patriotic holidays Thanksgiving should be a "red-letter" day. Every citizen has need of fully 
appreciating the historical significance of the day. The real life experience of our forefathers should be woven into the reading material so that it will help to give the children the true appreciation for the founders of our country.

Thanksgiving is a universal holiday. There is a need for developing appreciation and gratitude in the heart of each individual. Each year brings into our classrooms children who have comfortable homes, plentiful tables, abundant harvest, a beneficient government, free schools and religious liberty. Thanksgiving reading material should develop appreciation for these blessings.

\section{Lincoln's Birthday}

Lincoln's Birthday reading material for graỏes one, two and three should supply:

1. a knowledge of why we celebrate the day.

2. an appreciation of Abraham Lincoln's sympathy and consiceration for others.

3. a knowledge of outstanding traits in Lincoln's boyhood life.

4. a knowledge of freed om from slavery.

5. a knowledge of the united nation. 
The observance of Abraham Lincoln's Birthday has grown steadily until a number of states have designated it as a holiday. The Great Emancipator is today one of our foremost national heroes. His most unusual career which took him from the log cabin to the White House sets the hope of attainment before the most lowly and the most favored alike. This is an ambition which should arise early in a boy's or girl's Iife.

The need for true illustrations of good character traits may easily be supplied by reading of the experiences of Abraham Lincoln. Lincoln established in the United States the now inalienable right of all mankind to "life, liberty and the pursuit of happiness". Early in life he was dubbed by his friends and neighbors with the enviable title, "Honest Abe". On the frontier we find him inuring himself to toil. He was thoroughly acquainted with that phrase always necessary to success, hard work. His life was pure, untainted with the vices of lust for gain and greed for fame. Simple in living, steadfast in purpose, kindly in spirit, he towered among his fellows, exemplary of that manhood which all boys who would be of worth to mankind need to aspire. Humorous stories of Iincoln should not be neglected. 
There should be stories for establishing high standards of humor, Lincoln himself was a good story teller and had a keen sense of humor. Stories illustrating this characteristic of Lincoln furnish good reading for little children.

V George Washington's Birthday

Washington's Birthday reading material should supply:

1. a knowledge of why we celebrate the day.

2. a knowledge and appreciation of the flag.

3. a knowledge of Washington's boyhood.

4. a knowledge of Washington's life as a young soldier and as Commander of the American army.

5. a growing appreciation of the fact that honesty, bravery and loyalty are qualities that help to make

o one useful.

6. an appreciation of his part in establishing a new nation.

The desire for service to others, kindness and selfrespect may be created through reading stories of Washington. Discussions and activities growing out of these stories will deepen these desires. The story of the Iife of Washington gives material for glorifying those character traits desired for even our youngest citizens, namely: honesty, bravery, industry and loyalty. 


\section{Memorial Day}

Memorial Day rending material should supply:

1. a knowledge of why we celebrate the day.

2. an appreciation of the bravery and unselfishness of others.

3. a deeper understanding which should help the child to lay aside prejudice.

The desire of children to decorate indiscriminately the graves of the soldiers who had fallen during our Civil War led to the establishment of Memorial Day on May 30. The setting aside of this day on which to honor the soldiers who wore the blue and the gray has helped to knit together ties that were broken by the war. Surely, the reading material related to this important day should help to destroy prejudice in home, school and community. Nemorial Day stories should also deepen understanding, sympathy, and appreciation for others. Honoring our dead soldiers should aid children to appreciate the contribution of those who have given their lives in order to bring peace to our country. It should also cause them to be grateful for the blessings of peace and to be willing to sacrifice in order that it may be ours. 


\section{Flag Day}

Schools are dismissed before the celebration of this patriotic holiday. Material for the closing days of school should be centered around our Flag and should supply:

1. a knowledge of why we celebrate the day.

2. a knowledge and appreciation of the story of the first flag.

3. an attitude of respect and reverence for the flag.

4. a regard for some of the simple courtesies due the flag.

5. a knowledge of the meaning of the colors in the flag.

6. a knowledge of the number of stars and stripes.

7. a knowledge of how to locate the star of one's state on the Arnerican flag.

8. a love of country

Evaluation of the Tentative Criteria by Superintendents and Supervisors. These Tentative Criteria to be Used in Selecting Patriotic Holiday Reading Material for Grades one, Two and Three were mimeographed and sent to forty-six superintendents and supervisors, interested in primary children, of public schools of forty-six large cities of the United States. Each was asked to

1

See Appendix for list of forty-six superintendents and supervisors to whom Tentative Criteria were sent. 
evaluate the tentative criteria and to check those points which he felt were valid and necessary as a criterion for the selection of such material.

The purpose of mailing these tentative criteria to these superintendents and supervisors was to get the opinions of educators in many different sections of the United States. These men and women are not only vitally interested in the making of better citizens for our United States and the enrichment of their lives, but are experienced and well grounded in those underlying principles necessary for the setting up of such oriteria for the selection of patriotic holiday material for grades one, two and three. These various opinions are the basis for the permanent criteria set up at the close of this chapter.

The following table includes all points used in the tentative criteria and shows the results of the responses. to the questionnaire. A foot note gives reasons for the omission of those points which are not used in the permanent criteria. 


\section{TABLE $V$}

Tentative Criteria to be Used in Selecting

Patritoic Holiday Reading Material for

Grades 1,2 and 3

Percentage of 21 superintendents and supervisors

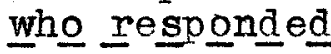

$---\cdots-\cdots-\cdots-\cdots$

I Columbus Day

The material should supply:

1. a knowledge of why_we celebrate the day._

2. a knowledge of the discovery of America and the geople_found_here by_Columbus._-_- ${ }_{1}$ l 1

3. a knowledge of the European way of life in_Columbus' d모. $-\ldots-\ldots-\ldots$

4. a knowledge of the_boyhood_of Columbus.

5. an appreciation of the dangers encount-

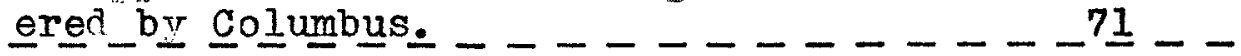

6. an admiration for such manly characteristics as persistence, determination, faith, hone, industry, self-reliance.

7. a knowledge of geography as:

38

a. directions

b. location of Europe, Asia, North and South America

c. location of Spain, Portugal, Italy, India, China, the West Indies

d. location of Atlantic, Pacific and. Indian Oceans

1

Omitted from permanent criteria because it was chosen by less than 70 percent of the superintendents and supervisors who responded to the questionnaire. 
Table V (continued)

Percentage of 21 superintendents and supervisors who_responded

II Armistice Day

The material should supply:

1. a knowledge of f $_{\text {hyy_we }}$ celebrate the day._ 100

2. an understanding of the blessings of universal peace - beginning with the home_and_community. _ _ _ $\ldots \ldots \ldots \ldots$

3. a feeling of respect for soldiers in

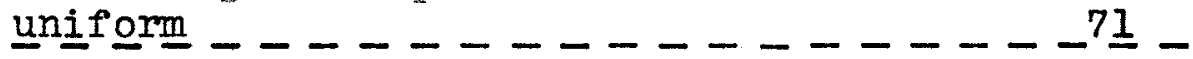

4. a feeling of respect and honor for those who fought_for_our_country. _ _ _ _ _ _ 81 I

5. a personal application of the principles

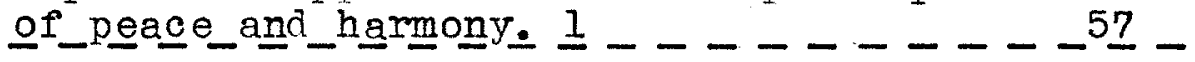

6. a deeper appreciation of democratic way

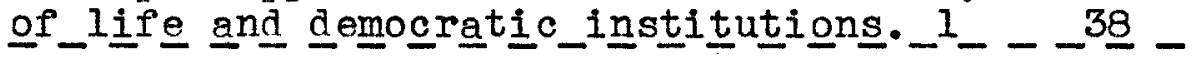

1

Omitted from permanent criteria because it was chosen by less than 70 percent of the superintendents and supervisors who responded to the questionnaire. 
Table V (continued)

Percentage of 21 superintendents and supervisors who_responded

---------
III Thanksgiving Day

The material should supply:

1. a knowledge of the way the Pilgrims celebrated the First Thanksgiving Day as compared with our Thanksgiving celebration.

2. a knowledge of the loyalty to religious_f faith_possessed_by the Pilgrims. 1 - 62

3. a knowledge of the courage, sense of gratitude, endurance, industry, selfreliance possesses_by the Pilgrims.

4. a knowledge of reasons for celebrating the First Thanksgiving Day as compared with our own reasons for celebrating Thanksgiving_Day.

5. a feeling of thankfulness for the comforts, opportunities and pleasures of home_and_community. _ _ $\ldots \ldots \ldots \ldots$

6. the opportunities to enjoy sharing benefits_with others.

7. a sense of the need of storing supplies for winter_use. 1 -

8. a knowledge of the reasons why the Pilgrims left their homes and came to_America. _ _ $\ldots \ldots \ldots$.

9. a knowledge of the principles upon which our country was founded. I

1

Omitted from permanent criteria because it was chosen by less than 70 percent of the superinendents and supervisors who responded to the questionnaire. 
Table V (continued)

Percentage of 21 Superintendents and Supervisors who_responded

IV Abraham Lincoln's Birthday

The material should supply:

1. a knowledge of why we celebrate the day._- - - - - - - - - - - -96

2. an appreciation of Abraham Lincoln's sympathy and consideration_for_others._. $\ldots \ldots \ldots \ldots$

3. a knowledge of outstanding traits in_Iincoln's_boyhood_liffe.........

$\nabla \quad$ George Washington's Birthday

The material should supply:

1. a knowledge of why we celebrate

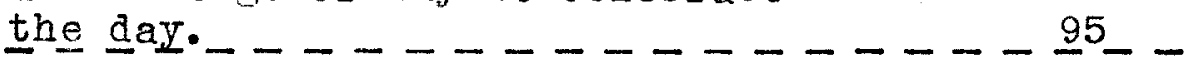

2. a knowledge and appreciation of

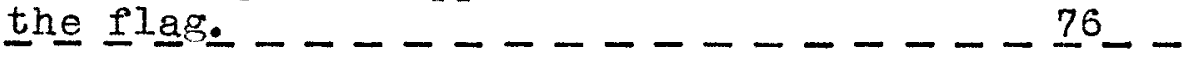

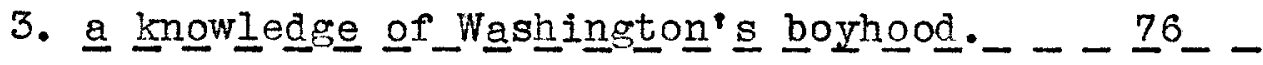

4. a knowledge of Washington's life as a young soldier and as Commander of

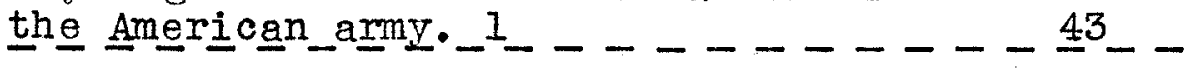

5. a growing appreciation of the fact that honesty, bravery and loyalty are qualities that help to make

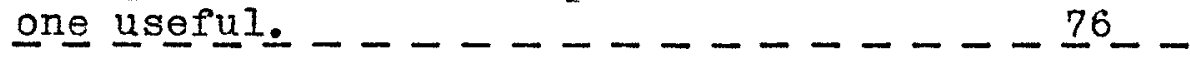

1

Ornitted from permanent criteria because it was chosen by less than 70 percent of the superintendents and supervisors who responded to the questionnaire. 
Table V (continued)

Percentage of 21 superintendents and supervisors who_responded

VI Memorial Day

The material should supply:

1. a knowledge of why we celebrate the day. $\ldots \ldots \ldots \ldots$

2. an appreciation of the bravery

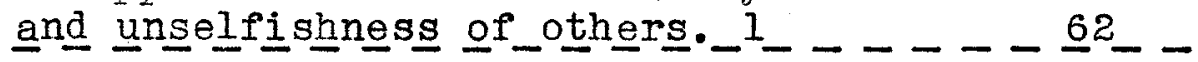

VII Flag Day

The material should supply:

1. a knowledge of why we celebrate the day._ _ - $\ldots \ldots-\ldots$

2. a knowledge and appreciation of the story of the fírst_flag.

3. an attitude of respect and reverence_for_the_flag._.

4. a regard for some of the simple

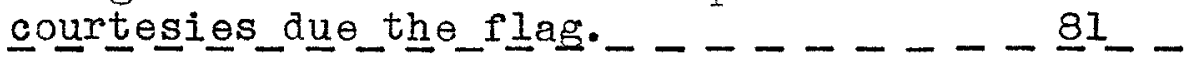

5. a knowledge of the meaning of the

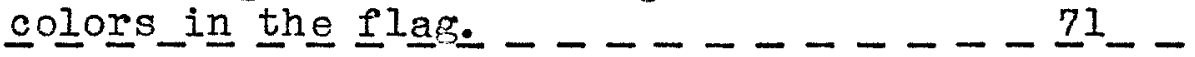

6. a knowledge of the number of stars

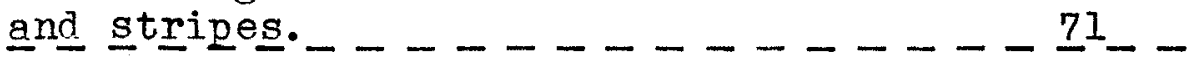

7. a knowledge of how to locate the star I of_one's_own_state_on the American_flag._ 52 _ -

8. a loeo the country.

1

Omitted from permanent criteria because it was chosen by less than 70 percent of the superintendents and supervisors who responded to the questionnaire. 
Permanent Criteria Set Up As the Result of Evaluation By Superintendents and Supervisors. After the tabulation of the responses of the twenty-one superintendents and supervisors to the questionnaire on the tentative criteria for the selection of patriotic holiday reading material in grades one, two and three, permanent criteria for selection of this reading material were set up.

The writer, after studying the results of those questionnaires which were returned, set up those criteria chosen by 70 percent of the superintendents and supervisors who responded to the questionnaire. 70 percent was decided upon since it is a commonly accepted passing grade in our educational systems. Those points in the tentative criteria which were chosen by less than 70 percent of these twenty-one superintendents and supervisors have been omitted from the permanent criteria. These criteria were used in the selection of patriotic holiday reading material in Chapter IV and Chapter $V$. The permanent criteria for selecting patriotic holiday reading material for grades one, two and three follows. 
Permanent Criteria to be Used in Selecting

Patriotic Holiday Reading Material

for

Grades 1,2 and 3

I. Columbus Day

The material should supply:

1. a knowledge of why we celebrate the day.

2. a knowledge of the discovery of America, the people found here by Columbus.

3. a knowledge of the boyhood of Columbus.

4. an appreciation of the dangers encountered by Columbus.

5. an admiration for such manly characteristics as persistence, determination, faith, hope, industry and self-reliance.

II Armistice Day

The material should supply:

1. a knowledge of why we celebrate the day.

2. an understanding of the blessings of universal peace - beginning with the home and community.

3. a feeling of respect for soldiers in uniform.

4. a feeling of respect and honor for those who have fought for our country. 


\section{Thanksgiving}

The material should supply:

1. a knowledge of the way the Pilgrims celebrated the First Thansgiving as compared with our Thanksgiving celebration.

2. a knowledge of the courage, sense of gratitude, endurance, industry, self-reliance possessed by the Pilgrims.

3. a knowledge of reasons for celebrating the First Thanksgiving Day as compared with our own reasons for celebrating Thanksgiving.

4. a feeling of thanksfulness for the comforts, opportunities and pleasures of home and community.

5. the opportunities to enjoy sharing benefits with others.

6. a sense of the need of storing supplies for winter use.

7. a knowledge of the reasons why the Pilgrims left their homes and came to America.

IV Abraham Lincoln's Birthday

The material should supply:

1. a knowledge of why we celebrate the day.

2. an appreciation of Abraham Lincoln's sympathy and consideration for others.

3. a knowledge of outstanding traits in Lincoln's boyhood life. 
$V \quad$ George Washington's Birthday

The material should supply:

1. a knowledge of why we celebrate the day.

2. a knowledge and appreciation of the flag.

3. a knowledge of Washington's boyhood.

4. a growing appreciation of the fact that honesty, bravery and loyalty are qualities that help to make one useful.

VI Memorial Day

The material should supply:

1. a knowledge of why we celebrate the day.

\section{Flag Day}

The material should supply:

1. a knowledge of why we celebrate the day.

2. a knowledge and appreciation of the story of the first flag.

3. an attitude of respect and reverence for the flag.

4. a regard for some of the simple courtesies due the flag.

5. a knowledge of the meaning of the colors in the flag.

6. a knowledge of the number of stars and stripes.

7. a love of the country. 
With these criteria as a guide the writer has made a collection of available patriotic holiday reading material on primary levels. She has also collected patriotic holiday reading materials on secondary school and adult levels with the idea of adapting them for use in lower grades. Chapter IV gives the criteria for adapting these stories to meet the needs of primary children. It also shows how the writer has applied these criteria in adapting a group of the stories. 
Chapter IV

Criteria For Adapting Stories 
Criteria For Adapting Stories

Introduction. Available patriotic holicay material on primary levels has been collected. Materials of this type on upper grade, secondary school and adult levels were also collected with the idea of adapting them for use in lower grades. All this collected material was judged according to standards set up in the Criteria to be Used in Selecting Patriotic Holiday Reading Material for Grades one, Two and Three. This criteria is in the latter part of Chapter III.

Criteria for Adapting Stories. After the selection of patriotic holiday reading material much of it has been adapted by the writer of this thesis to meet the needs of the first, second and third grade children. The criteria used in making these adaptations have been:

1. The material should have unity.

2. It should have coherence.

3. It should contain a sequence of time and ideas.

4. It should have simplicity of organization, sentence structure and vocabulary.

Seven of these revised stories relating to the life of Christopher Columbus were submitted to seventeen

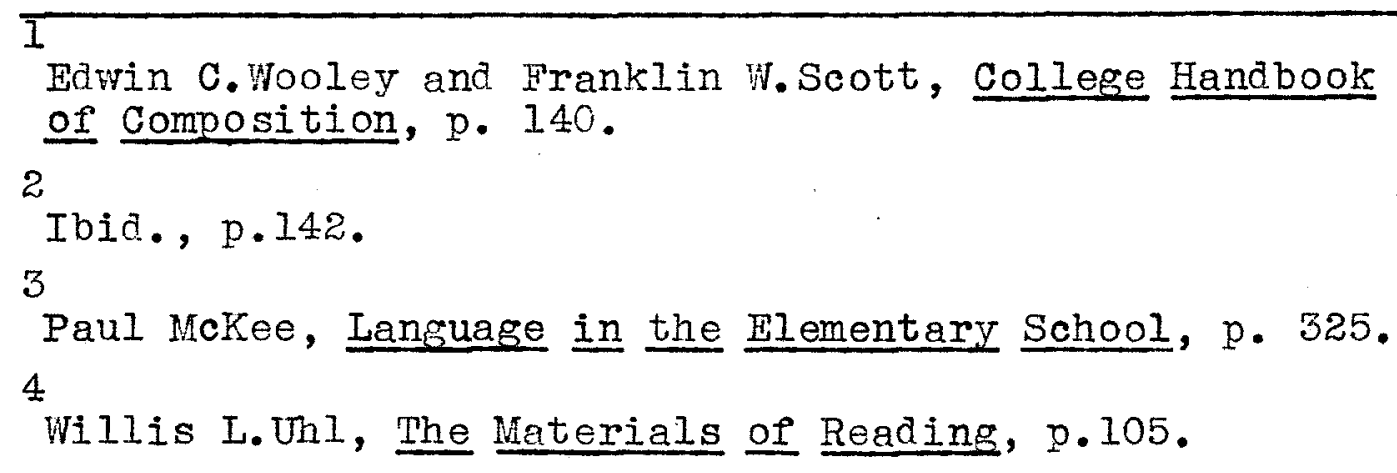


classroom groups for the reaction of teachers and pupils. Each of the seventeen teachers received sixteen mimeographed copies of each story. This was enough to accomodate the average reading group in Louisville Public Schools. Accompanying each set of stories was a questionnaire relating to the difficulty of the vocabulary, the adaptability, the attractiveness of style, the unity and coherence of thought, the background necessary for understanding of the story. Also, there was a question regarding any suggestions by teachers and pupils. A second revision was made of these Columbus Day stories based on the results from the questionnaires answered by those teachers and pupils who had used them.

A summary of the work done in making the first adaptations will illustrate the method used.

A discussion of the adaptation of "A Little Boy of Genoa" will illustrate the attempts that have been made to reach a standard in simplicity and sequence of ideas.

In its original form, this story is confusing to the young child. The first four paragraphs discuss the happenings of one day during the childhood of Columbus. The next five paragraphs discuss a voyage made by columbus after he became a young man. They describe the shipwreck off the northern coast of Africa and tell of the new geographic concepts which Columbus gained

\section{See Appendix}

2

Frances G. Wickes, "A Little Boy of Genoa", Happy Holidays, pp. 31-34. 
through contacts with sailors whom he met at Carthage. Thus, the enjoyment of the story requires a mental bridging of several years and quick transitions from one situation to another. Young children are not able to make so many transitions within one short story. Therefore, from the material in this story, "A Little Boy of Genoa", the author of this thesis has written two stories. They are, "When Christopher Columbus Was a Boy" and "An Old Dream and a New one". The first, "When Christopher Columbus Was a Boy" discusses the events of one day during the boyhood of Columbus. The second, "An Old Dream and a New One" describes Columbus' first voyage and tells of the new ideas that were born in his brain at this time. An analysis of the first one of these stories will illustrate the method which has been used in all of the adaptations.

"When Christopher Columbus Was a Boy" was divided into two parts by the writer of this thesis. This was done in order that the first part might introduce the main character, give the setting, and supply enough background to enable the children to understand and appreciate the story.

The original story ${ }^{l}$ plunges the children abruptly

1 Frances G. Wickes, "A Little Boy of Genoa", Hapoy Holidays, pp.3l-34. 
into the scene, beginning thus:

"A little boy stood on the wharf watching a white-sailed vessel put out to sea. How he longed to go with her across the great, wide, mysterious ocean! What happened when the ship sank out of sight below the horizon? What wonderful lands lay beyond? Would he ever see them? Smaller and smaller grew the ship. Some one jostled against him and he started as though from a dream." 1

The young child, knowing nothing about the "Iittle Boy of Genoa" is wholly unprepared to identify himself with him and to follow his speculations as to the probable destiny of the outgoing ship. Therefore, an attempt has been made to give the children some idea of the city in which Christopher Columbus lived, of his parents, of the house in which he lived, and of his childhood activities, interests and dreams. Some of the information needed for this introduction has been gleaned from phrases and sentences scattered through the original story, but much of it was supplied from many sources and resulted from wide reading of biography and history. Part one of the story, "Wen Christopher Columbus Jas a Boy", is an introduction to the character, columbus.

1

Frances G. Wickes, "A Iittle Boy of Genoa", Happy Holidays, pp. 31-34

2

If Fall Kerbey, "Genoa, Where Columbus Learned to Love the Sea", The National Geographic Magazine, IIV

(September, 1928) pp.333-352 
When Christopher Columbus was a Boy

When Christopher Columbus was a boy,

he lived in the city of Genoa, Italy. This city is beside the sea. Ships from many lands came into its harbor to unload their cargoes and to receive other goods which they carried to foreign ports.

Christopher's father, Domenico Columbus, was a weaver. All the neighbors were weavers and all the little children Christopher played with were weaver's children. They would either be weavers or sailors some तay.

The house in which Columbus lived was built of stone and was very tall and very narrow. It was five stories high, but was only as wide as one room. You may think that this house must have been very queer looking, but, really, the house each side of it was of the same height and were crowded up so close to it that you could not tell where one house left off and the other began. on the first floor, there were two rooms, one behind the other. The one in front was the larger of the two, but it was dark and gloomy. At the back of it, there was a winding wooden stairway which led to the second floor.

The front room of the second story was lighter and more airy than the one below it, for it had two windows in the front wall. This was the living room of the columbus family. The rooms on the third floor were used for bedrooms and there was one very small room on the second floor behind the stairway. Some people think that this was christopher's room.

We do not know much about the fourth and fifth stories of this

1 Adapted, by the writer of this thesis, from "A Iittle Boy of Genoa". 
house because after the house became very old those two stories had to be torn away. That was in 1885 . Most of Christopher's play time was spent on the wharf where many ships were always anchored. Sometimes he would go on board these strange vessels. He made friends with the sailors and they told him many interesting things about the sea and about the countries which they had visited. Christopher had a cousin who was

a sea captain. Sometimes he would visit the boy's home. These were happy times for Christopher. He would sit and listen to his cousin as he told stories of the distant lands that he had visited in his trading ships. Then he would say to himself, "Some day I shall be a sailor. Perhaps I shall even be a sea captain like my cousin."

Part Two of "When Christopher Was a Boy" follows. It tells of the happenings of one day during the boyhood of columbus. It is made up of bits of story telling which have been reassembled from the original story, "A Little Boy of Genoa".

The contents of the first paragraph have been rearranged so that they tell a story in a direct manner and so that events occur in logical sequence. For the sake of unity and clarity the events narrated in one paragraph have been told in the following four paragraphs:

"I shall tell you a story of a part of just one day in the life of Christopher Columbus, the little boy of Genoa. 
Christopher had been down by the sea all morning. Now he stood on the wharf watching a white-sailed vessel sail away. How he longed to go with her across the great, wide, mysterious sea! He watched the ship as it grew smaller and smaller. At last it sank out of sight below the horizon.

"Now the great ship has gone out of sight", he said to himself. "I wonder what really happened to it when it seemed to go over the top of the hill in the sea. Where is the big ship going? What wonderful lands will it see? Shall I ever see the strange lands to which the ship is going?"

Some one jostled against the boy and he jumped and looked about him as if he were awakening from a dream. What a long time he had been standing there. It was time to go home.

After the breaking down of one paragraph of "A Iittle Boy of Genoa" into the above four paragraphs the writer of this thesis made an adaptation of the next two paragraphs of the original story, "A Little Boy of Genoa".

The following analysis will explain the rewriting of these two paragraphs.

Reason for Original Form Making Changes Changes Made

(1) "for his fa- This material This material was ther was a weaver. belongs in the not repeated here. There were many introduction weavers in the of the story city of Genoa. and has alreadAll the neigh- $y$ been placed bors were weavers in the first and all the lit- part of "When 


\section{tle chilaren \\ Christopher \\ played with \\ were weaver's \\ children, and \\ would be either \\ weavers or sail- \\ ors some day". \\ (2) $\cdot$. Now \\ the little boy \\ slipped into the \\ seat by his fa- \\ ther."}

(3) "The great

ship has sailed,

Father," he said.

"How I wish I

had sailed with

her." "Some day, some day," answered his father.

"But see now,

here is some wool

to comb."
Christopher Columbus Was a Boy".
The last sentence needed to be slightly changed for the sake of smoothness.

Conversation much more easily read by children if each quotation forms a paragraph.
This sentence was changed so that it reads: "So he went into the weaving room and slipped into the seat beside his father".

Two new paragraphs were written. One contains the comment of the boy and the other the father's reply.

Third Paragraph of Original Story

$\begin{array}{ll}\text { (1) Many an hour } & \text { This paragraph } \\ \text { did the little } & \text { slows up the } \\ \text { Christopher sit } & \text { story and the } \\ \text { by his father } & \text { first sentence } \\ \text { combing wool } & \text { is unnecessary } \\ \text { and watching } & \text { as the idea ex- } \\ \text { the shuttle fly } & \text { pressed has beed } \\ \text { back and forth. } & \text { used in the in- } \\ \text { But the shuttle } & \text { troduction. } \\ \text { did not fly so } & \\ \text { swiftly as his } & \\ \text { thoughts as they } & \\ \text { followed the } & \\ \text { great ships at } & \\ \text { sea." }\end{array}$

The first sentence was omitted. For the sake of smoothness, definiteness, and story movement, she last part was thus expressed: "The little boy took the handful of tangled wool which his father gave him. He began to straighten

it but he kept thinking of the 
Reason for

Original Form Making Changes

Changes Made

great ship that

had sailed away

to unknown lands.

He dreamed of the

day when he should

become a sailor

and should have

exciting adven-

tures on the sea

and in far away

lands."

By making the above mentioned changes, the ideas

expressed in the second and third paragraphs of the

original story were expressed as follows:

When he reached his home, his

mother, Susanna Columbus, was

cooking the noonday meal. His

father, Domenico Columbus, was

working at his loom. Christo-

pher heard the "Boom, boom",

of the shuttle. So he went

into the weaving room and slip-

ped into the seat beside his

father.

"The great ship has sailed,

father," he said. "How I wish

I had sailed with her."

"Some day, some day," an-

swered his father. "But, see

now, here is some wool for

thee to comb."

The little boy took the

handful of tangled wool which

his father gave him. He be-

gan to straighten it but he

kept thinking of the great

ship that had sailed away

to unknown lands. He dreamed

of the day when he should be-

come a sailor and should have

exciting adventures on the

sea and in far away lands. 
These revisec Columbus Day stories were submitted to seventeen Louisville teachers for classroom use. A questionnaire accompanied each set of stories. Tables VI, VII, VIII, IX, X, XI, and XII are summaries of the responses to these questionnaires.

\title{
Table VI
}

\begin{abstract}
Summary of Responses of Seventeen Teachers to the Questionnaires on First Revision of "When Columbus Was a Little Boy"
\end{abstract}

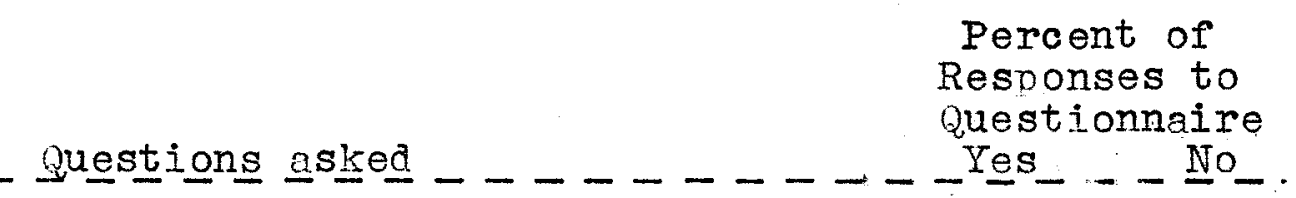

1. What percent of your children could read_this story? _ $\ldots \ldots \ldots-\underline{60} \cdot \underline{88}-39.12$

2. Did they_enjoy_it? _ _ _ - _ $100 \cdot \ldots \ldots$

3. Do you think that the style in which it is written is suitable for children_of your_grade? $\ldots$ - $\ldots$ - $82.35-17.65$

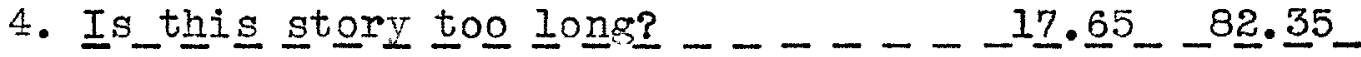

5. Does the understanding of this story require a broacer background of information than

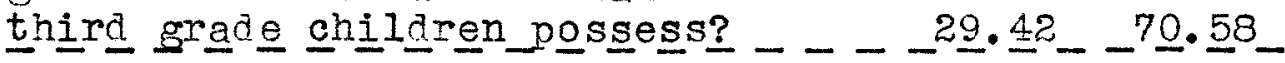

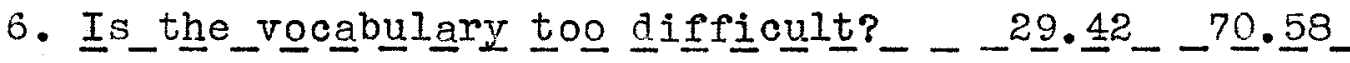

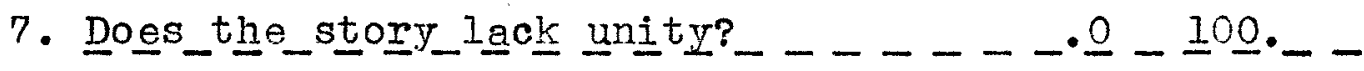

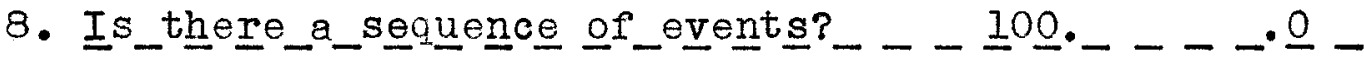

9. Could the sentence structure be improved? _ $\ldots \ldots \ldots \ldots$

10. Have you other criticisms, suggestions_or comments? _ _ _ _ _ 
Summary of Criticisms, Suggestions and comments. The following are some of the responses to question 10 of Table VI.

"The children were thrilled. The story was excellent." "The children asked for help with sixteen words. No member of the group could give any information about Columbus."

"The children liked this story better than any of them." "This story furnished a splendid background for language work." "Too much detail, especially about home." "A number of the children expressed themselves freely" about the story, saying that they enjoyed it. one child repeated this statement after school. Their only criticism was that they couldn't tell e's from o's on the mimeographed paper. This did slow the oral reading somewhat. I realize that in a book with regular primary print that the stories could be read more easily." "Iven though the vocabulary was a bit difficult this story provided much information."

"I believe a map pointing out different places would help the children follow Columbus in these stories." "Jostled, horizon, gloomy and vessels were difficult words." "The story was read with great interest. I tested them on their ability to recall important events in the story and it was satisfactory." 
Table VII

Summary of Responses of Seventeen Teachers to the Questionnaire, on First Revision of

"An Old Dream and a New One"

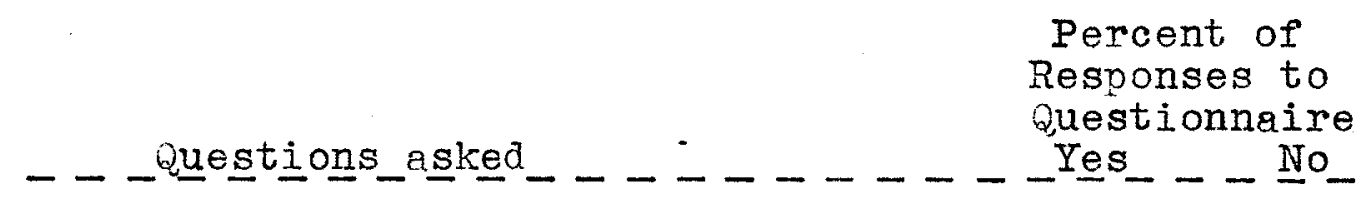

1. What percent of your children could read_this story? _ _ . . . 69 .

2. Did they_enjoy_it? _ $\ldots \ldots \ldots \ldots-100 \cdot \ldots \ldots .0$

3. Do you think that the style in which it is ritten is suitable

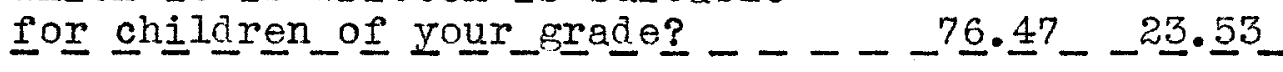

4. Is_this story too long? _ _ _ _ _ . 0 o _ 100. -

5. Does the understanding of this story require a broader background of information than

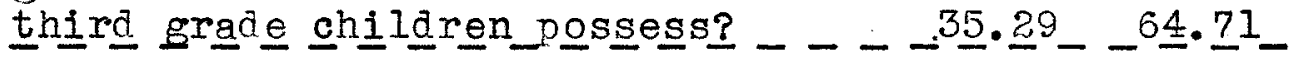

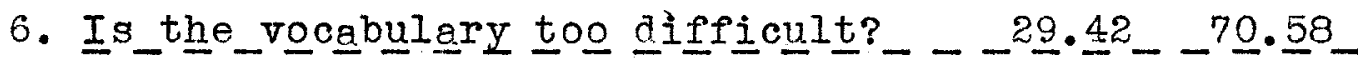

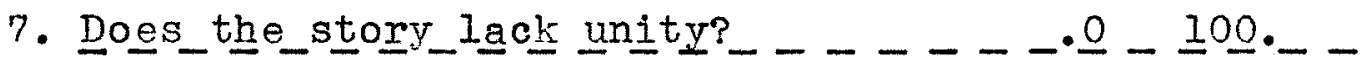

8. Is_there_a_sequence of_events

9. Could the sentence structure

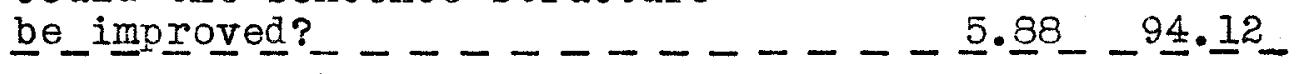

10. Have you other criticisms, suggestions_or comments? _ _ $\ldots \ldots \ldots$ 100. $\ldots \ldots .0$

Summary of Criticisms, Suggestions and comments. The following are some of the responses to question 10 of Table VII. 
"This story was the most exciting one. We borrowed some history readers from older children and talked about the trading customs at that time; the cruelty of the Turks, etc. These stories that you sent us make the holiday 'Columbus Day' more interesting as the children have had very little, but the principle facts about America's discovery."

"We borrowed a globe and had several discussions on the shape of the earth." "This story was the favorite of the Columbus collection. Excellent language work grew out of it." "The children said this one vas very interesting, but it wasn't long enough."

"The shining shores and white palaces of Genoa' were hard for the children to understand. Wrapped in flames' was a difficult phrase." "To the question, 'What did you learn about Columbus?" the teacher received the following children's answers:

'brave'

'stuck to his word'

'wouldn't give up'

'strong in action'

'kept his ideas'

'had faith in himself'

'had faith in others'

'kept a promise'

'made his dream come true by not giving up.' 


\section{Table VIII}

\section{Summary of Responses of Seventeen Teachers}

to the Questionnaire on First Revigion of

"Trying To Make A Great Dream Come True"

Percent of

Responses to

Questionnaire

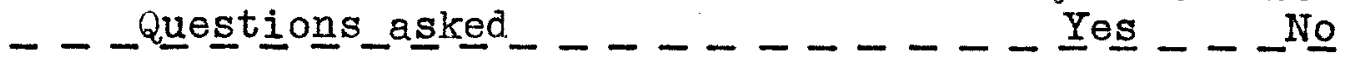

1. What percent of your children

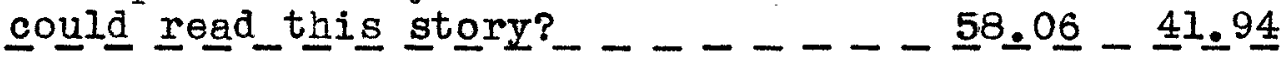

2. Did they_enjoy_it? $-\ldots-\ldots$

3. Do you think that the style in which it is written is suitable

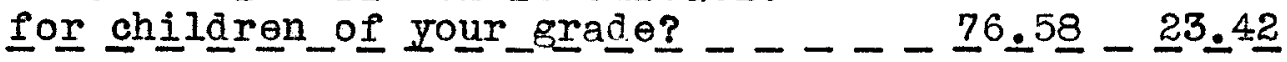

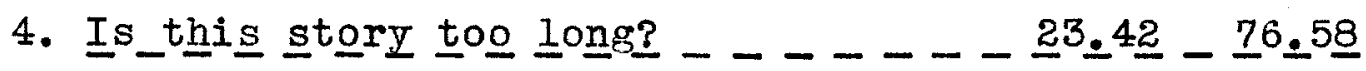

5. Does the understanding of this story require a broader background of information than

thirrd grade children_possess? - - - $29.42-10.5 \underline{8}$

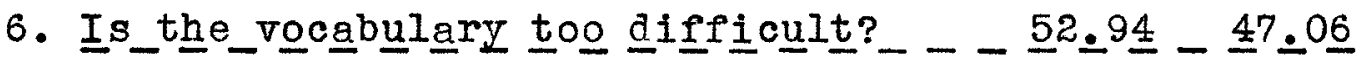

7. Does_the_story_lack unity?

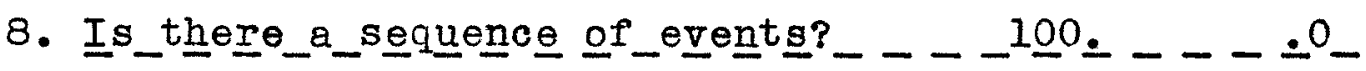

9. Could the sentence structure be

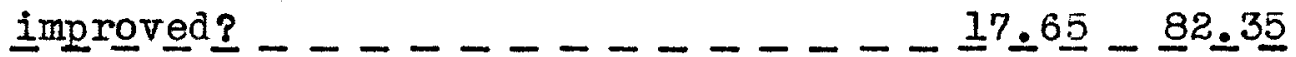

10. Have you other criticisms, sug-

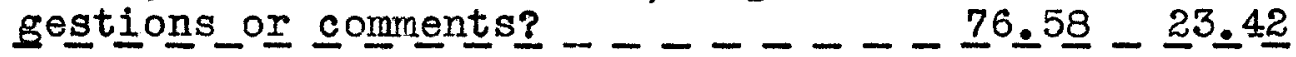

Summary of Criticisms, Suggestions and Comments. The following are some of the responses to question 10 of Table VIII. 
"Wished the story was longer."

"Did not enjoy it as much as the others. Was necessary to use the map."

"Names of the ships should have been given. Practically every child said that this was the best story of them all. Several said that they hoped they could read these stories in a book."

"Information had to be given by the teacher, such as, meaning of charts, trading, convent, monks and shape of the earth."

"Some chilỏren brought reference books after reading this story."

"Children were so stimulated that a globe and map were brought in. One child located the equator and explained the seasons to the group." 


\section{Table IX}

\section{Summary of Responses of Seventeen Teachers}

to the Questionnaire on First Revision of

"A Great Dream Comes True"

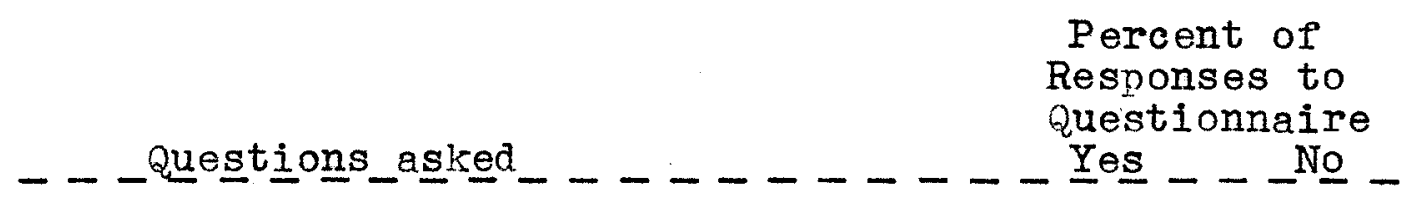

1. What percent of your children could read_this story? _ _ _ _ _ 61.

2. Did they_enjoy_it?_ $\ldots \ldots-\ldots \ldots-100 .-\ldots$

3. Do you think that the style in which it is written is suitable for chilldren_of your_grade?

4. Is_this story too long?

5. Does the understanding of this story require a broader background of information than third grade children_possess? _ - _ $17.6 \underline{5}$ - $92.3 \underline{5}$

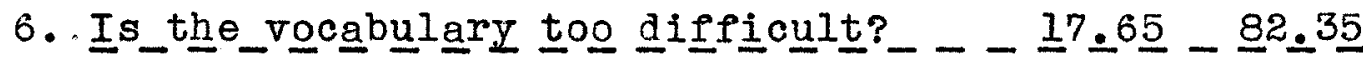

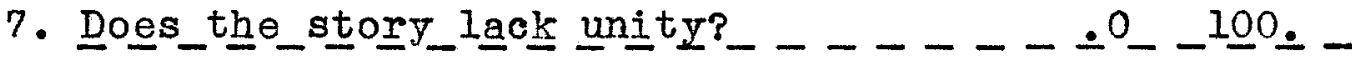

8. Is_there_a_sequence of eventts?

9. Could the sentence structure

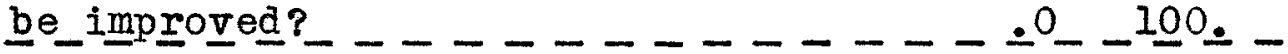

10. Have you other criticisms, sug-

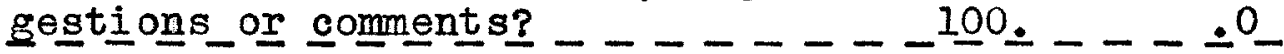

Summary of Criticisms, Suggestions and Comments. The following are some of the responses to question 10 of Table IX. 
"Children were interested as story progressed." "This story held their interest." "Comprehension of this part was much better." "One child said that this story showed more of the hardships Columbus had to endure than any of the others had."

"The children got some good pictures in story." "The majority of children read this story well. It provided much motivation for discussion." "This story seemed to have the best sequence and sentence structure. It was the favorite." 
Summary of Responses of Seventeen Teachers

to the Questionnaire on First Revision of

"The Natives of San Salvador"

Percent of
Responses to
Questionnaire

Summary of oriticisms, Suggestions and Comments. The following are some of the responses to question 10 of Table X. 


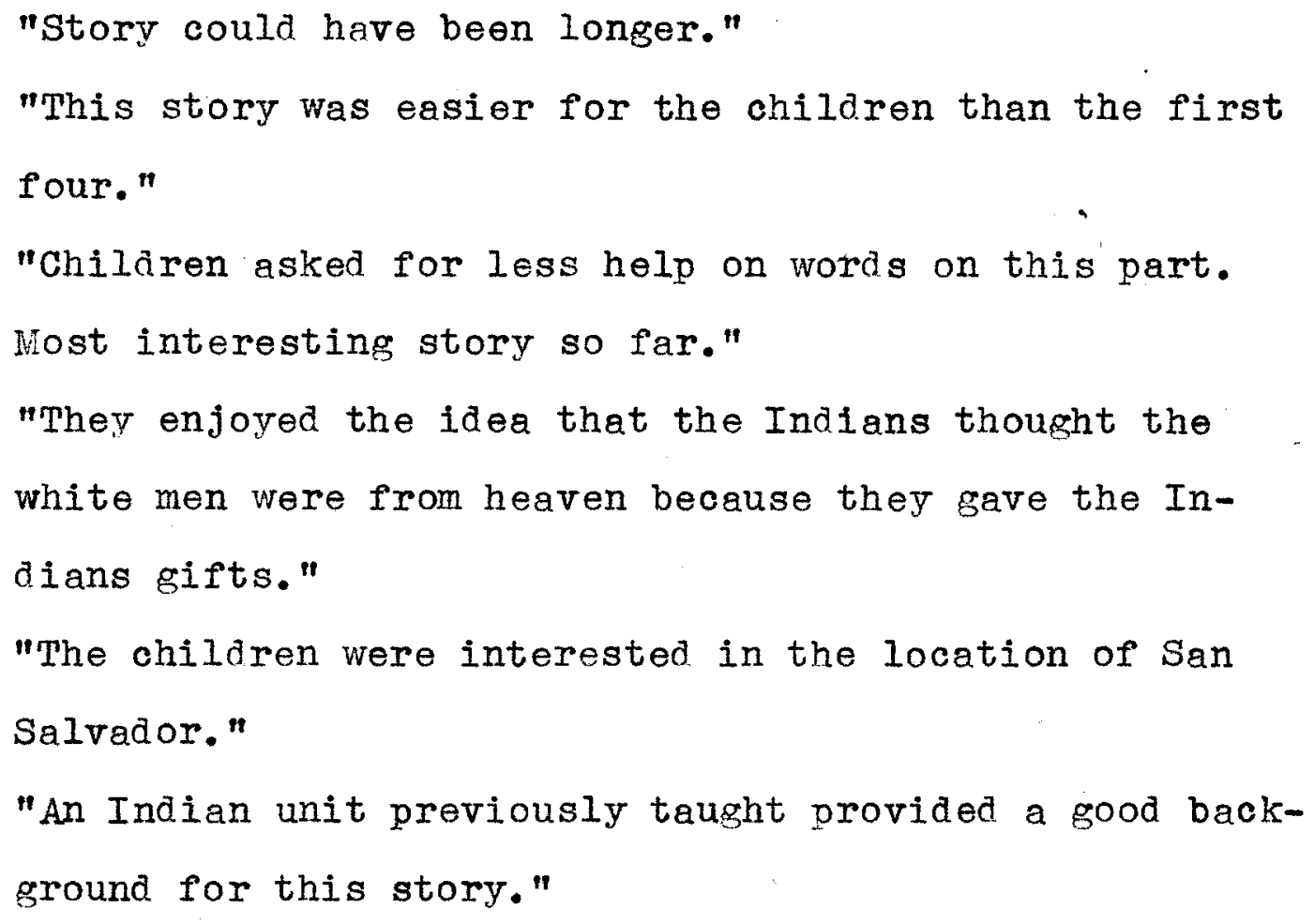


$\underline{\text { Table }} \underline{X I}$

Summary of Responses of Seventeen Teachers to the Questionnaire on First Revision of "The Return of the Mad Sailor"

Percent of Responses to Questionnaire

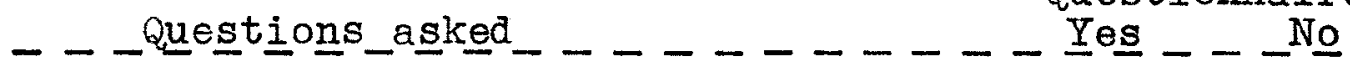

1. What percent of your children could read_this story? _ $\ldots \ldots \ldots-\underline{78}^{8} 66$ _ 21.34

2. Did they_enjoy_it? _ $\ldots \ldots-\ldots-100 . \ldots-.0$

3. Do you think that the style in which it is written is suitable for childaren_of your_grade? - $\ldots$ - $-\underline{8} 2.35$ - $17.6 \underline{5}$

4. Is_this story too long? $\ldots \ldots \ldots \ldots \ldots$

5. Does the understanding of this story require a broader background of information than

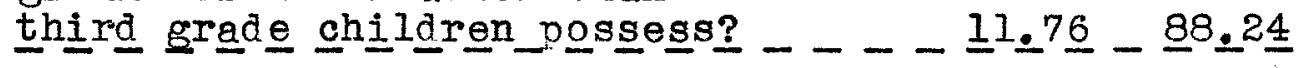

6. Is_the_vocabulary too difficulte? _ - $82.35-17.65$

7. Does_the_story_lack unitty? _ . . . . .0 - 1000

8. Is_there_a_sequence of_events? _ _ - I00. $\ldots \ldots$

9. Could the sentence structure be_improved? - $\ldots \ldots-\ldots-\ldots$

10. Have you other criticisms, suggestions_or comments? $\ldots \ldots \ldots-\ldots$

Summary of Criticism, Suggestions and comments. The following are some of the responses to question 10 of Table XI. 
"The carry-over from these stories has been very good. Every now and then when the children are looking through the library books, they say, 'Oh here is a story about Colunbus'. They have read all the stories they could. find. They have asked many questions about the earth, stars and moon. Thanks for letting us read these stories." "In spite of the vocabulary being difficult for my class the children have thoroughly enjoyed these stories. They provided information for an assembly program. Pictures were made to illustrate each story. The general information has provided a background for geography." "These stories have enriched our vocabulary. We found several opportunities to use the dictionary to look up the meanings of the nautical terms." "Children were sorry they were so near the end of the stories."

"This story was enjoyed very much. The chiloren enjoyed telling it. Later they wrote their interpretations of the stories without the help of original stories or of the teacher."

"The suspense in this story is excellent. The children could hardly wait to see if columbus returned." "The first sentence in the last paragraph sounds awkward." "Assembled, audience, chamber, royal presence are difficult words."

"The qualities of good character that Columbus expressed were really understood and appreciated."

"A refreshing story. The children enjoyed its style very much." 


\section{Table XII}

Summary of Responses of Seventeen Teachers to the Questionnaire on First Revision of "The Simplest Thing in the World"

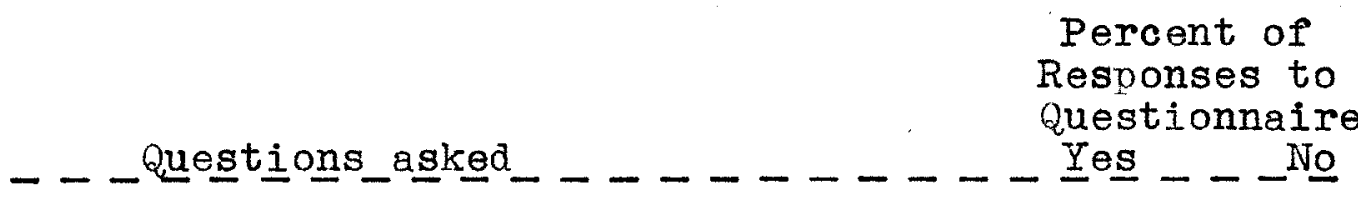

1. What percent of your children

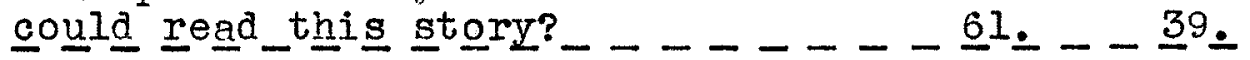

2. Did they_enjoy_it? $\ldots \ldots \ldots-\ldots \ldots$

3. Do you think that the style in which it is written is suitable for children_of your_grade? - $\ldots$ - $\underline{5}^{3}-\ldots \underline{4}^{7}$.

4. Is_this story too long? $\ldots \ldots \ldots \ldots-\ldots$

5. Does the understanding of this story require a broader background of information than

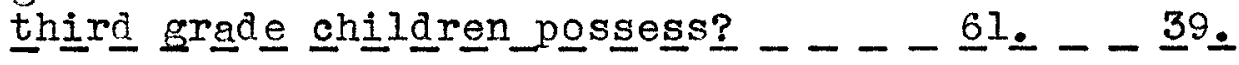

6. Is_the_vocabulary too diffịcult?

7. Does_the_story_lack unity?

8. Is_there_a_sequence of _events?

9. Could the sentence structure be improved? _ - $\ldots \ldots-\ldots-\ldots$

10. Have you other criticisms, suggestions_or comments? _ $\ldots \ldots \ldots \ldots$

Summary of Criticisms, Suggestions and Comments. The following are some of the responses to question 10 of Table XII. 
"My children could not see the point of the story." "As far as the children were concerned this was the least interesting and understandable." "The children did not get the idea. They were not much concerned about the jealousy of Columbus' friends." "Several said that they felt as if this story was not finished. The ending was not satisfying." "This story seemed to bring an anti-climax feeling to the group of stories." 
The responses of the seventeen Louisville teachers as summarized in Tables VI through XII were carefully studied. Then a second revision of the Columbus Day stories was made by the writer of this thesis. In the second revision of the stories, "The Simplest Thing in the World", was omitted because it seemed the least attractive and interesting to the majority of the children who used it. To some it seemed to be an anti-climax to the rest of the stories. For these reasons and those results listed on Table XII, it was omitted.

The following analysis will illustrate the method used in the second revision of the Columbus Day stories. In this analysis, the column headed "First Revision" gives direct quotations from the first revision of the Columbus Day stories which was made by the writer of this thesis. In the column headed "Changes Made in the Second Revision", are found direct quotations which are changes made in the "First Revision". In the second column which is headed, "Reasons for Making Changes" are found the author's reasons for making changes listed in the third column. 
An Analysis of the Method Used by the Writer of This Thesis in Revising the Columbus Day Stories After Suggestions Had Been Made by the Teachers and Pupils Who Read Them

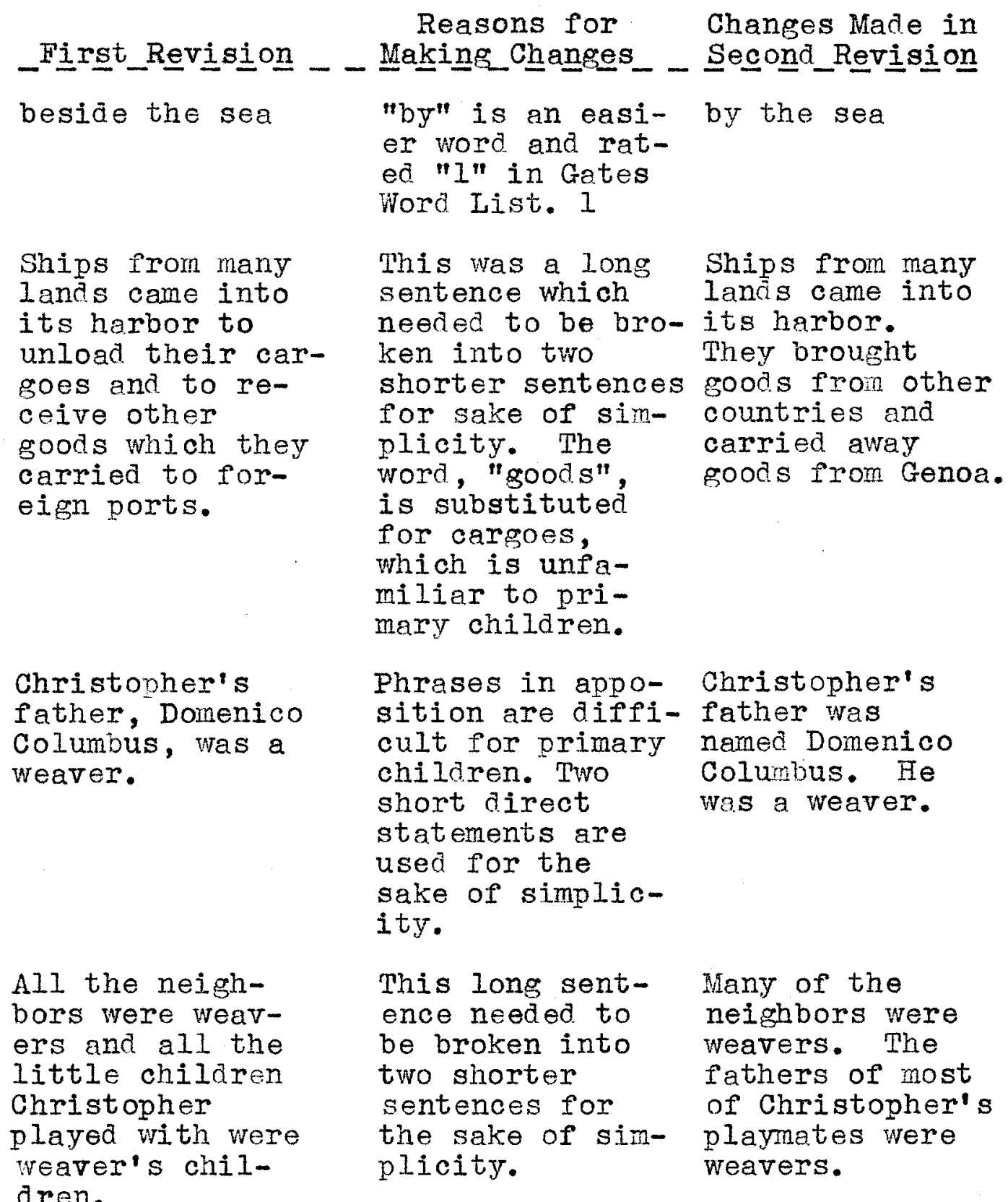

$I$

Arthur I. Gates, A Reading Vocabulary for the Primary Grades, pp. 5-20. 


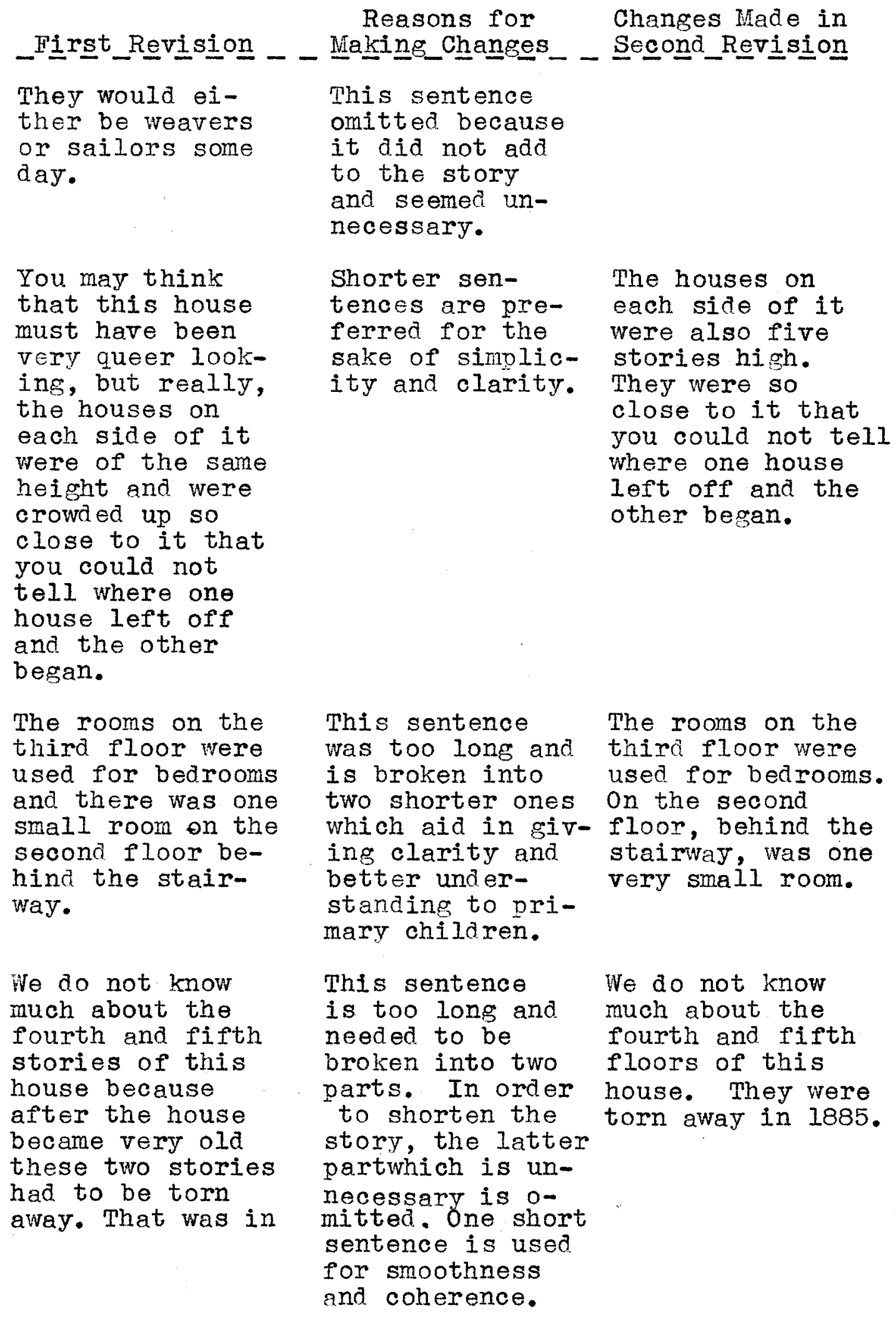




\begin{tabular}{|c|c|c|}
\hline $\begin{array}{l}\text {-First_Revision } \\
\text { strange vessels }\end{array}$ & $\begin{array}{l}\text { Reasons for } \\
\text { Making_Changes - } \\
\text { "vessels" is an } \\
\text { unfamiliar word. } \\
\text { "ship" which is } \\
\text { on the Gates } 1 \\
\text { Word Iist is sub- } \\
\text { stituted. }\end{array}$ & $\begin{array}{l}\text { Changes Made in } \\
\text { Second_Revision } \\
\text { strange ships }\end{array}$ \\
\hline $\begin{array}{l}\text { He made friends } \\
\text { with the sailors } \\
\text { and they told him } \\
\text { many interesting } \\
\text { things about the } \\
\text { sea and about the } \\
\text { countries which } \\
\text { they had visited. }\end{array}$ & $\begin{array}{l}\text { This sentence } \\
\text { was too long. } \\
\text { It needed to be } \\
\text { cut into two } \\
\text { shorter sentences } \\
\text { for the sake of } \\
\text { simplicity and } \\
\text { clarity of } \\
\text { thought. }\end{array}$ & $\begin{array}{l}\text { He made friends } \\
\text { with the sailors. } \\
\text { They told him } \\
\text { many interesting } \\
\text { things about the } \\
\text { sea and about the } \\
\text { countries which } \\
\text { they had visited. }\end{array}$ \\
\hline $\begin{array}{l}\text { I shall tell you } \\
\text { the story of a } \\
\text { part of just one } \\
\text { day in the life } \\
\text { of christopher } \\
\text { Columbus, the } \\
\text { little boy of } \\
\text { Genoa. }\end{array}$ & $\begin{array}{l}\text { The first part } \\
\text { of this sen- } \\
\text { tence was un- } \\
\text { necessary and } \\
\text { slowed up the } \\
\text { story. }\end{array}$ & $\begin{array}{l}\text { This is the story } \\
\text { of just one day } \\
\text { in the life of } \\
\text { Christopher Co- } \\
\text { lumbus, the little } \\
\text { boy of Genoa. }\end{array}$ \\
\hline $\begin{array}{l}\text { Christopher had } \\
\text { been down by the } \\
\text { sea all morning. }\end{array}$ & $\begin{array}{l}\text { This sentence } \\
\text { needed rearrang- } \\
\text { ment to give } \\
\text { movement and } \\
\text { smoothness to } \\
\text { the story. The } \\
\text { past tense is } \\
\text { preferrable to } \\
\text { the past perfect } \\
\text { for primary } \\
\text { children. }\end{array}$ & $\begin{array}{l}\text { Farly in the morn- } \\
\text { ing, christopher } \\
\text { went down to the } \\
\text { sea. }\end{array}$ \\
\hline $\begin{array}{l}\text { Now he stood on } \\
\text { the wharf watch- } \\
\text { ing }\end{array}$ & $\begin{array}{l}\text { "Now" is not nec- } \\
\text { essary and is o- } \\
\text { mitted because } \\
\text { tense is changed } \\
\text { in previous sen- } \\
\text { tence. }\end{array}$ & $\begin{array}{l}\text { He stood on the } \\
\text { wharf watching }\end{array}$ \\
\hline
\end{tabular}

I

Arthur I. Gates, A Reading Vocabulary for the Primary Grades, pp. 5-20. 


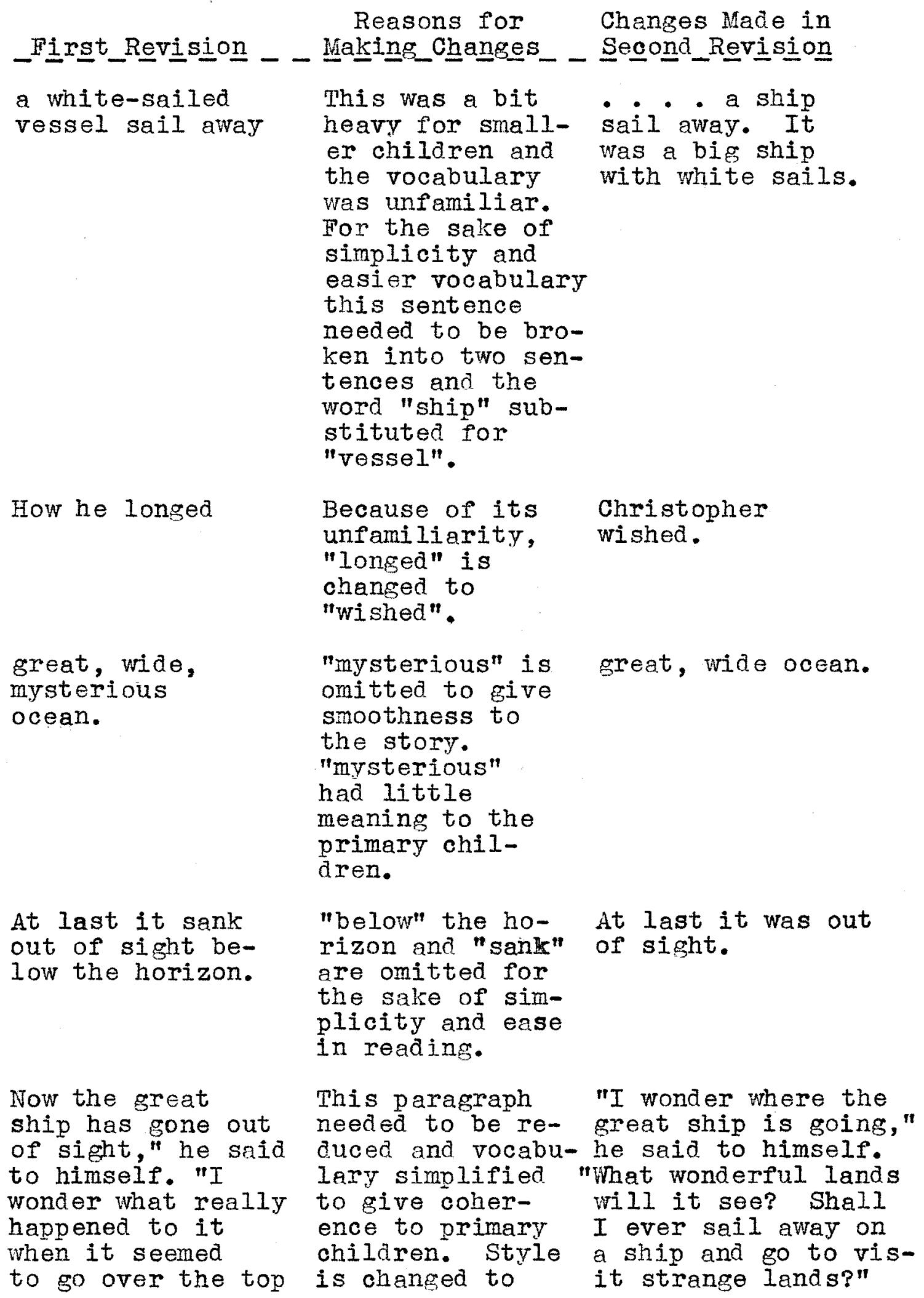




\begin{tabular}{|c|c|c|}
\hline First Revision & $\begin{array}{l}\text { Reasons for } \\
\text { Making Changes }\end{array}$ & $\begin{array}{l}\text { Changes Made in } \\
\text { Second Revision }\end{array}$ \\
\hline $\begin{array}{l}\text { of the hill in } \\
\text { the sea. Where } \\
\text { is the big ship } \\
\text { going? What won- } \\
\text { derful lands will } \\
\text { it see? Shall I } \\
\text { ever see the } \\
\text { strange lands to } \\
\text { which the ship } \\
\text { is going?" }\end{array}$ & $\begin{array}{l}\text { that of smaller } \\
\text { children. }\end{array}$ & \\
\hline $\begin{array}{l}\text { Someone jostled } \\
\text { against the boy } \\
\text { and he jumped } \\
\text { and looked about } \\
\text { him as if he were } \\
\text { awakening from a } \\
\text { dream. }\end{array}$ & $\begin{array}{l}\text { "jostled" is a } \\
\text { difficult word } \\
\text { for younger } \\
\text { children. This } \\
\text { sentence was } \\
\text { long and needed } \\
\text { to be broken into } \\
\text { two shorter sen- } \\
\text { tences. }\end{array}$ & $\begin{array}{l}\text { Someone happened } \\
\text { to bump against } \\
\text { the boy and he } \\
\text { jumped and looked } \\
\text { about him. } \\
\text { He ielt as if he } \\
\text { were awakening } \\
\text { from a dream. }\end{array}$ \\
\hline $\begin{array}{l}\text { What a long time } \\
\text { he had been stand- } \\
\text { ing there. It was } \\
\text { time to go home. }\end{array}$ & $\begin{array}{l}\text { His thoughts are } \\
\text { changed to a di- } \\
\text { rect quotation, } \\
\text { because this } \\
\text { style is more } \\
\text { attractive to } \\
\text { smaller chil- } \\
\text { dren. }\end{array}$ & $\begin{array}{l}\text { He thought, "I } \\
\text { have been stand- } \\
\text { ing here a long } \\
\text { time. It is time } \\
\text { to go home." }\end{array}$ \\
\hline $\begin{array}{l}\text { When he reached } \\
\text { home, his mother } \\
\text { Susanna Columbus, } \\
\text { was cooking the } \\
\text { noonday meal. His } \\
\text { father, Domenico } \\
\text { Columbus, was work- } \\
\text { ing at his loom. } \\
\text { Christopher heard } \\
\text { the "Boom, boom" } \\
\text { of the shuttle. } \\
\text { So he went into } \\
\text { the weaving room } \\
\text { and slipped into } \\
\text { the seat beside } \\
\text { his father. }\end{array}$ & $\begin{array}{l}\text { The names in ap- } \\
\text { position are o- } \\
\text { mitted and are } \\
\text { used in shorter } \\
\text { sentences. The } \\
\text { paragraph is } \\
\text { simplified to } \\
\text { give smoothness } \\
\text { and coherence. }\end{array}$ & $\begin{array}{l}\text { When he reached } \\
\text { home, his mother } \\
\text { was cooking din- } \\
\text { ner. Her name was } \\
\text { Susanna columbus. } \\
\text { His father was wear- } \\
\text { ing. Christopher } \\
\text { heard the noise } \\
\text { of his loom. Chris- } \\
\text { topher went in and } \\
\text { sat down by his } \\
\text { father. }\end{array}$ \\
\hline
\end{tabular}


In order to be sure that the vocabulary is simple enough for the average third grade child, the author of this thesis used the Gates Word List in making her first revision of the Columbus Day stories. After she had studied the responses of the seventeen teachers who had used these stories she felt a need for further simplification of the vocabulary. Accordingly she referred again to the Gates Word Iist and whenever it was possible to do so, she substituted words of a higher frequency for the one which she had previously used. The following story illustrates the method used in checking the second revision by the Gates Word List. Words omitted from the Gates Word List are underscored.

1

Arthur I. Gates, A Reading Vocabulary for the Primary Grades, pp. 5-20. 


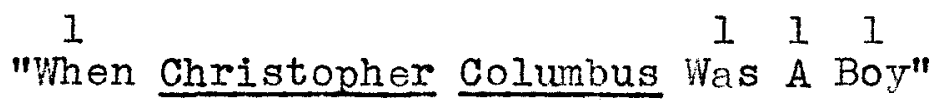

1
When

the city of Genoa, Italy. This city $\begin{aligned} & \text { I } \\ & \text { Is }\end{aligned}$

$\begin{array}{lllllllll}1 & 1 & 2 & 1 & 1 & 1 & 1 & 2 & 1\end{array}$ from many lands came into its harbor. They brought goods

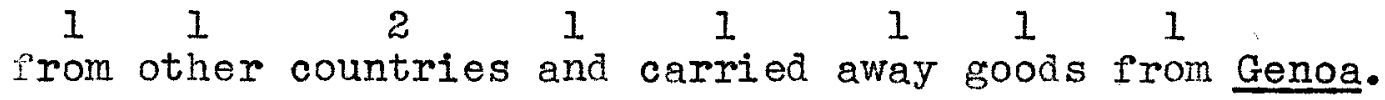

111

Christopher's father was named Domenico Columbus.

$\begin{array}{llllllll}1 & 1 & 1 & 1 & 1 & 1 & 3 & 1\end{array}$

He was a weaver. Many of the neighbors were weavers.

$\begin{array}{lllllll}1 & 1 & 1 & 2 & 1 & 3 & 1\end{array}$

The fathers of most of Christopher's playmates were

weavers.

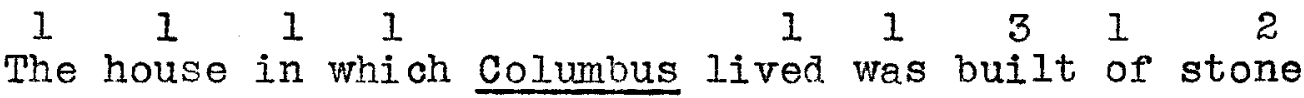

$\begin{array}{lllllllllll}1 & 1 & 1 & 2 & 1 & 1 & 4 & 1 & 1 & 1 & 1\end{array}$ and was very tall and very narrow. It was five stories

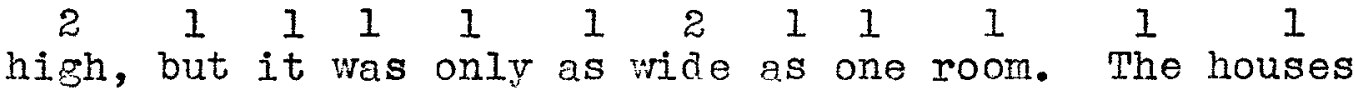

$\begin{array}{lllllllllll}1 & 1 & 2 & 1 & 1 & 1 & 2 & 1 & 1 & 2 & 1\end{array}$ on each side of it were also five stories high. They

$\begin{array}{llllllllllll}1 & 1 & 1 & 1 & 1 & 1 & 1 & 1 & 1 & 1 & 1 & 1\end{array}$ were so close to it that you could not tell where one

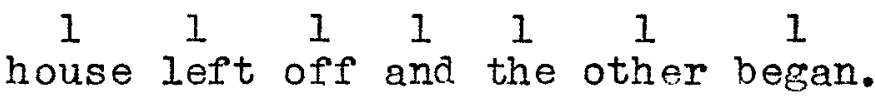

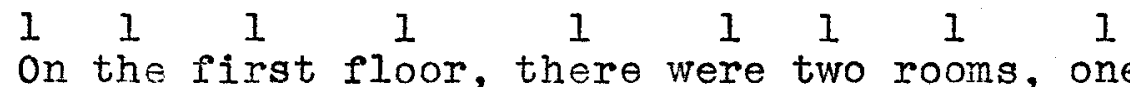
$\begin{array}{lllllllllll}1 & 1 & 1 & 1 & 1 & 1 & 3 & 1 & 1 & 2 & 1\end{array}$ behind the other. The one in front was the larger of 
$\begin{array}{llllllllllll}1 & 1 & 1 & 1 & 1 & 2 & 1 & 1 & 1 & 1 & 1 & 1\end{array}$ the two, but it was dark and gloomy. At the back of it,

$\begin{array}{lllllllllll}1 & 1 & 1 & 1 & 4 & 3 & 1 & 1 & 2 & 1 & 1\end{array}$ there was a winding wooden stairway which led to the $\begin{array}{cc}2 & 1 \\ \text { second } & 1 \\ \text { floor. }\end{array}$

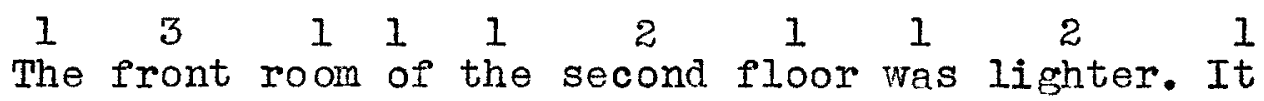

$\begin{array}{llllllllllll}1 & 2 & 2 & 1 & 1 & 1 & 2 & 1 & 1 & 1 & 1 & 1\end{array}$ was more airy than the one below it, because it had two

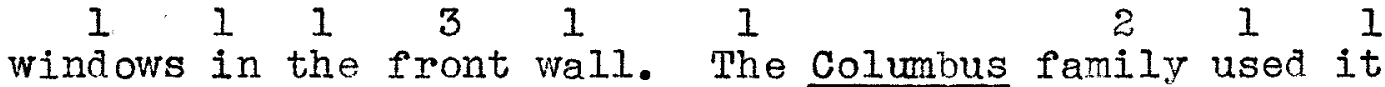
1111 for their living room.

$\begin{array}{llllllllll}1 & 1 & 1 & 1 & 3 & 1 & 1 & 1 & 1 & 3\end{array}$ The rooms on the third floor were used for bedrooms.

$\begin{array}{lllllllllll}1 & 1 & 2 & 1 & 2 & 1 & 3 & 1 & 1 & 1 & 1\end{array}$ on the second floor, behind the stairway, was one very

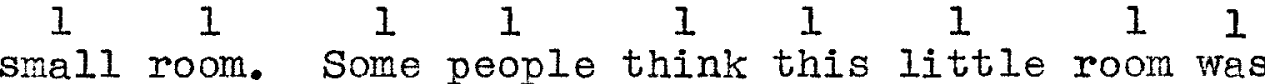

Christopher's bedroom.

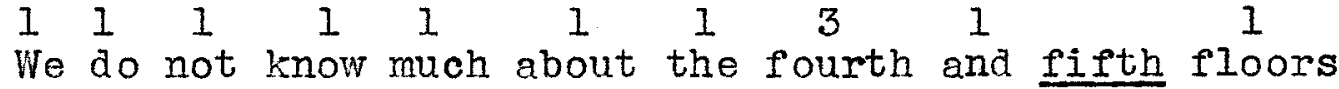

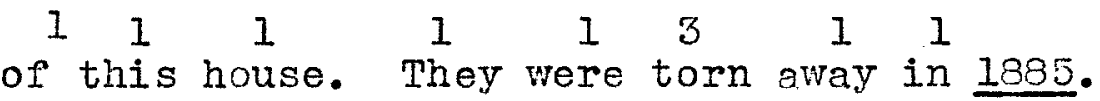

Christopher spent most of his play time on the wharf $\begin{array}{llllllll}1 & 1 & 1 & 1 & 2 & 1 & 1\end{array}$ where ships from many countries were always anchored.

$\begin{array}{llllllllll}2 & 1 & 1 & 1 & 1 & 2 & 1 & 3 & 1 & 1\end{array}$ Sometimes he would go on board these strange ships. He

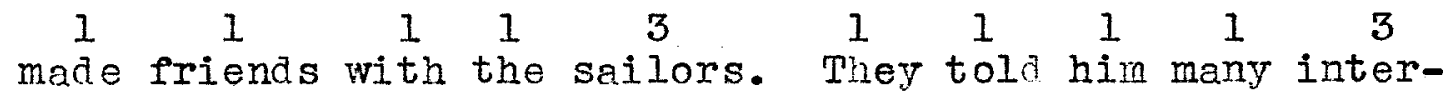
esting things about the sea and about the countries which $\stackrel{1}{1} \stackrel{1}{2}$ they had visited. 


\section{Table XIII}

Word Rating of the Second Revision of the Columbus Day Stories According to Gates.

\section{1}

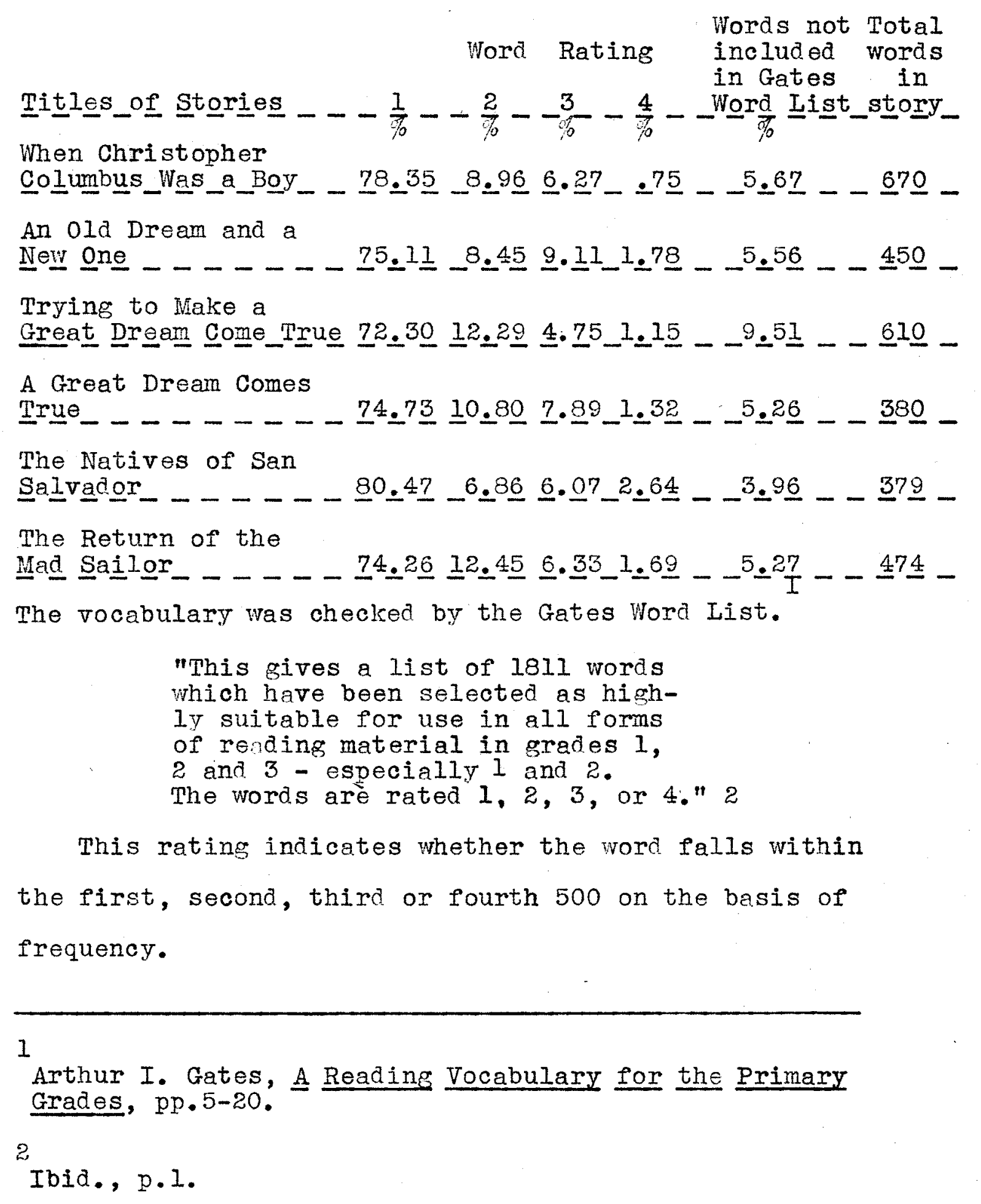

This rating indicates whether the word falls within the first, second, third or fourth 500 on the basis of frequency.

1

Arthur I. Gates, A Reading Vocabulary for the Primary Grades, pp. 5-20.

2

Ibid., p.I. 
Criteria for adapting patriotic holiday stories for use in grades one, two and three have been set up in this chapter. An explanation of the use of these criteria has been made.

After setting up these criteria and deciding upon the method of adaptation, the writer has adapted stories relating to Columbus Day. These adaptations are found in Chapter V. 
Chapter V

Conclusion of Thesis

and

One Group of Adapted Stories 


\author{
Conclusion of Thesis \\ and \\ One Group of Adapted Stories
}

This chapter is made up of two parts. They are: (1) Conclusions and (2) The Final Revision of the Columbus Day Stories. These stories were first adapted according to the criteria set up in Chapter IV, then tried out in seventeen classrooms of Louisville and finally rewritten after suggestions had been made by the seventeen teachers who had used them.

I Conclusions. This investigation has three major conclusions.

A There is a dearth of patriotic holiday reading material for grades one, two and three. This fact was established as a result of the following investigations:

1. A review of the mriter's personal experience was made. This revealed that throughout eighteen years of experience as a teacher in primary grades there has continued to grow a consciousness of the need for patriotic holiday reading material in grades one, two and three. 2. A survey of courses of study revealed a need for patriotic holiday reading material in primary 
grades. An examination of twenty-one courses of study revealed a lack of suggestions for activities connected with our patriotic holidays. Nine of these representative courses of study make no mention of patriotic holidays. Of the remaining twelve only four list reading among the patriotic activities and only one of these includes a bibliography of available patriotic holiday material. 3. An analysis of present day textbooks revealed the need for patriotic holiday reading material. A survey of forty-four present day textbooks which include two thousand seventy-one stories and which are available for grades one, two and three showed a total of only thirty-three stories available for use preceding the seven patriotic holidays occuring during the school calendar year. One and six-tenths percent are patriotic holiday stories. Thirteen stories are for use on Thanksgiving. Not all of these are related to the First Thanksgiving. Eleven stories are available for George Washington's Birthday while only five stories relate to Lincoln's Birthday and four to Columbus Day. No suitable material for Armistice Day or Memorial Day was included 
in the forty-four present day textbooks which were examined. This survey of the present day textbooks showed that most of the information about the patriotic holidays must be given by the teacher or gleaned at home - and not from the textbooks. 4. A questionnaire to teachers of primary grades showed a need for patriotic holiday reading material. There is a definite consciousness of the need for patriotic holiday reading material in primary grades as revealed by the responses to a questionnaire by 273 primary teachers of Kentucky, Ohio, Illinois, Georgia and Virginia. In the above survey, it was found:

a. that ninety per cent of the primary teachers represented felt a definite need for patriotic holiday reading material and b. that 99.5 per cent felt a need for an anthology containing patriotic holiday reading material for primary grades.

B This need for patriotic holiday reading material in grades one, two and three can be met by following, with certain minor changes, the procedure which is given in detail in this thesis. The writer's handling of Columbus Day stories will 
illustrate this procedure. She determined to meet the need for Columbus Day material by adapting a group of Columbus Day stories. In adapting this material these things were done. 1. Questionnaires were sent to teachers for suggestions for patriotic holiday material. These questionnaires revealed a desire on the part of the teachers for the material and gave such suggestions as:

a. A series of stories on each holiday would be of great value.

b. The material should be authenic..

c. Material should have a vocabulary suitable to the children's ability to comprehend. d. It would be helpful to have a good bibliography of patriotic holiday stories under headings,

(I) For the teacher to read

(2) For the children to read

e. Stories about Pilgrims getting ready for the First Thanksgiving needed.

f. We need material to promote love of country and hero worship.

g. More biographical stories would be helpful. $h$. Stories in sets to be used in reading groups would be helpful. 
2. Criteria were set up for selecting patriotic holiday reading material. Tentative criteria were set up first. They related to the selection of available materials first on primary grade levels and other materials on upper grade, secondary school and adult levels. These later materials were selected to be used as source materials. 3. Tentative Criteria for Selecting Patriotic Holiday Reading Material were checked and evaluated by a representative group of presumably expert leaders in education. Forty-six superintendents and supervisors of forty-six representative cities of the United states were selected to do this evaluating. Twenty-one of these responded to the tentative criteria. With these responses as a guide, permanent criteria were set up. Each criterion receiving the approval of 70 percent of the superintendents and supervisors was set up in the pemanent criteria for the selecting of Patriotic Holiday Material. 4. Patriotic Holiday Material for Columbus Day was selected using these criteria set up for the selection of such materials. Most of the materials available were above primary grade levels. Yet 
these materials possessed the information for the primary grades as set up in these Criteria for Columbus Day. After gleaning much material, it was found that there was a wealth of source material and story material on adult and upper grade level which if adapted and supplemented to meet the needs of primary pupils would be informational ana valuable.

5. Criteria for adapting stories were set up. These resulted from study and investigation. These criteria are:

a. The material should have unity. b. It should have coherence. c. It should have sequence of time and ideas. d. It should have simplicity of organization, sentence structure and vocabulary.

6. The available selected patriotic holiday reading material was adapted to meet the needs of primary pupils. The author's principle concern was to retain much of the style and attractiveness of the original stories. She was careful to observe the the criteria which she had set up for the adapting of material. 
7. The vocabularies of the stories were checked 1

by the Gates Word Iist. Synonyms were selected from this list and substitued for difficult words in the adapted stories. An effort was made to hold a high standard for the vocabulary and not to reduce it below the level of a second or third grade reading ability.

8. The adapted stories were put to the test of classroom use. A group of adapted stories for Columbus Day were submitted in mimeographed form to seventeen third grade classroom groups for the reaction of the teachers and punils. Each classroom received a set of sixteen accompanied by a questionnaire, relating to the style, vocabulary and adaptability of the story to primary levels. 9. An analysis of the fincings resulting from the classroom use of the adapted storien was studied. These findings revealed that the adapted stories were read with pleasure and profit by the pupils of seventeen of Louisville's primary classrooms. However to meet the need of the children whose reading ability is below the level of a high second grade, further simplifications of vocabulary were

$\bar{I}$

Arthur I Gates, A Reading Vocabulary for the Primary Grodes, pD. 5-20.

2

See p.99 of this thesis. 
deemed necessary.

10. On the basis of findings of classroom teachers, further simplifications of the adapted stories were made. These findings had shown a need for simplification of vocabulary. Accordingly, Gates Word List was again referred to and, in cases where the vocabulary had proven too difficult for some children, words of a higher frequency were substituted for those previously used.

11. A vocabulary check of the second revision of the Colurbus Day stories vas made. The purpose of this check was to determine what percentage of the words were classified as "1", "2", "3" and "4" words. This second vocabulary check revealed that 75.37 percent of the words were "I" words. It also showed that 94.13 percent of all the words in the stories fell within groups "I", "2", "3" and "4" of the Gates Word List. It is of significance that, including proper names, only 5.87 percent of all the words used in the stories did not fall within these groups. 12. The final adaptations are for submission to primary grades for classroom use.

I

This rating, according to Gates Word List, indicates whether the word falls within the first, second, third or fourth 500 on the basis of importance. 
These final adaptations of stories for Columbus Day appear in Part II of this chapter. The 1 minor changes which the writer would make in the above procedure are related to the vocabulary. Knowing the findings resulting from the classroom use of the adapted stories she would follow steps 1 - 6 as given above. Step 7 would be the same as step 11. Steps 8 - 10 would remain as stated above. Step 11 would be: additional changes based on the findings resulting from classroom use. Step 12 would be: Submission of adaptations to primary grades for classroom use.

C Improvement in attaining more and better materials are suggested. It is the writer's opinion after making this study of the needs for patriotic holiday reading materials for grades one, two and three that the dearth of this material can be met by:

a. the use of a larger number of patriotic holiday stories in First, Second and Third Grade Readers. At least one story for each patriotic holiday should be in each textbook of each grade level;

b. the contributions of teachers and other 
authors who would write and adapt patriotic holiday stories on lower grade levels;

c. the use of mineographed copies of an outine showing a suitable method to be used in making adaptations of stories: these copies would be supplied by Boards of Education.

II The Final Revision of the Columbus Day Stories. Part II of this chapter contains the final adaptations of the Columbus Day stories. It is hoped that this collection of stories will be of practical valus as:

1. reading material for advanced groups in grade two;

2. reading material for children in grade three;

3. stories to be read or told to children in grades one, two and three;

4. stories which children will enjoy telling in book clubs, as parts of assembly programs, to a group of their own classmates or to another class;

5. stories thich can be successfully dramatized by children of grades one, two and three;

6. stories which will fumish background and inspiration for much work in industrial and fine arts; 7. stories which will furnish much worthwhile information about our patriotic holidays; 
8. stories which will become the basis of interesting units of work;

9. stories which will enrich our teaching of history;

10. stories which vill give our children a true appreciation of our American ideals ana American patriots;

11. stories which will help to develop the deep and sincere patriotism which is founded upon understanding and appreciation.

The writer's belief is that, in view of the findings of this study that, by using the criteria set up in Chapter III for the selecting of patriotic holiday reading material for primary grades and by using the criteria for adapting this material as set up in Chapter IV, that the dearth of patriotic holiday reading material can be overcome by those interested in the prinary child. The final adaptations of the Columbus Day stories follow. 


\section{COLUIBUS DAY STORIES \\ Second Revision}

1. When Christopher Columbus Was a Boy

2. An OId Dream and a Nevi one

3. Trying to Make a Great Dream Come True

- Trying to Make a Great Dream Come True

4. A Great Dream Comes True

5. The Natives of San Salvador

6. The Return of the Mad Sailor

\section{$I$}

An adaptation of parts from Frances G. Wickes, "A Little Boy of Genoa", Happy Holidays, po. 31-34. Source of the information concerning the Columbus home: McFall Kerbey, "Genoa, Where Columbus Learned to Love the Sea," National Geographic Magazine,LIV, (September, 1928), pp.33-352.

2

Frances G. Wickes, "A Little Boy of Genoa", Happy Holidays, pp. 31-34

3

Frances G. Wickes, "A Dream That Came True", Happy Holidays, pp. 34-39.

4

"The Journal of Columbus", The Golden Book Magazine, II, (October, 1925), pp. 47 $\overline{1-4} 74$.

5

Sarah A. Haste, "The Return of the Mad Sailor", Frances G. Wickes, Happy Holidays, pp. 39-42. 
When Christopher Columbus Was a Boy

When Christopher Columbus was a boy, he lived in the city of Genoa, Italy. This city is by the sea. Ships from many lands came into its harbor. They brought goods from other countries and carried away goods from Genoa. Christopher's father was named Domenico Columbus. He was a weaver. Many of the neighbors were weavers. The fathers of most of Christopher's playmates were weavers.

The house in which Columbus lived was built of stone and was very tall and very narrow. It was five stories high, but it was only as wide as one room. The houses on each side of it were also five stories high. They were so close to it that you could not tell where one house lest off and the other began.

On the first floor, there were two rooms, one behind the other. The one in front was the larger of the two, but it was dark and gloomy. At the back of it, there was a winding wooden stairway which led to the second floor.

The front room of the second floor was lighter. It was more airy than the one below it, because it had two windows in the front wall. The Columbus family used it for a living room.

The rooms on the third floor were used for bedrooms. 
On the second floor, behind the stairway, was one very small room. Some people think this little room was Christopher's bedroom.

We do not know much about the fourth and fifth floors of this house. They were torn away in 1885 . Christopher spent most of his play time on the wharf where ships from many countries were always anchored. Sometimes he would go on board these strange ships. He made friends with the sailors. They told him many interesting things about the sea and about the countries which they had visited. Christopher had a cousin who was a sea captain. Sometimes he would visit the boy's home. These were happy times for Christopher. He would sit and listen to his cousin as he told stories of the distant lands he had visited. Then he would say to himself, "Some day I shall be a sailor. Perhaps I shall be a sea captain like my cousin."

\section{II}

This is the story of just one day in the life of Christopher Columbus, the little boy of Genoa. Early in the morning, Christopher went dow to the sea. He stood on the wharf watching a ship sail 
away. It was a big ship with white sails. Christopher wished that he could go on it across the great, wide ocean. He watched it as it grew smaller and smaller. At last it was out of sight.

"I wonder where the great ship is going," he said to himself. "What wonderful lands will it see? Shall I ever sail away on a ship and go to visit strange lands?" Some one happened to bump against the boy and he jumped and looked about him. He felt as if he were awakening from a dream. He thought, "I have been standing here a long time. It is time to go home."

When he reached home, his mother was cooking dinner. Her name was Susanna Columbus. His father was weaving. Christopher heard the noise of the loom. Christopher went in and sat down by his father. "I have been watching a great ship sail away," he said. "How I wish I had sailed with her."

"Some day," said his father. "Some day you shall be a sailor. But now I have some wool for you to comb." The little boy took the handful of tangled wool which his father gave him. He began to straighten it. As he worked, he kept thinking of the ship that had sailed away to strange lands. He dreamed of the day when he would becone a sailor and have exciting adventures on the sea and in far-away countries. The next story will tell how this dream came true. 
An 0ld Dream and a New One

The day had come when Christopher's dream was coming true. He was going to sail away in a big ship with his cousin, the sea captain. His mother and his father and his younger brothers and sisters were sorry to say goodbye to him for they knew they would miss him. But Christopher was excited and happy.

As the ship moved away from the shore, he hardly looked back. He was thinking of the adventures that were ahead of him, not of the beautiful city that lay behind him.

It was not long before he had an adventure which was exciting, but sad. His cousin's ship was attacked by an enemy. Soon it was set on fire. Those on board had two choices. They must either become prisoners of the enemy or jump into the sea. Christopher did. not want to become a prisoner of the enemy, so he jumped from the deck. He found a heary piece of wood. He held on to it, and swam to the nearest land. This land was the northern shore of Africa. There he found a large number of sailors. They crowded around him and asked him to tell them of his adventures. They were very kind to him. They gave him some dry clothes and some money so that he could go back to Genoa. 
The place where Columbus had gone ashore was the harbor of a large city called Carthage. In that city, there were seamen from many countries. Columbus talked with them and they told him many strange things.

one old sallor said, "If your cousin's ship had. sailed four miles farther, you would have come to the edge of the world. Strange beasts are on guard there. If you had sailed past them, you would have fallen off. You would have gone down, down, down - no one knows where."

Some of the seamen did not agree with this old sailor. They said the earth was round and not flat. They said that if sailors would sail far enough west they could reach the shores of China and India. Young Christopher Columbus thought that was wonderful. He thought of it by day and dreamed of it by night.

After a time a ship from Genoa came into port at Carthage. On it Christopher sailed back to Genoa. He carried a new dream in his mind. His old dream had been "Some day I will be a sailor". That dream had come true. His new dream was, "Some day I shall sail west and reach China and India". The next story will tell how he tried to make this new dream come true. 
Trying To Make A Great Dream Come True

I

Columbus knew that he would have to work hard if he ever made his new dream come true, so he began at once. He went on many royages. He learned to sail a ship. He learned to tell directions by watching the moon and stars. He learned how to draw maps and charts. He learned all that he could about the world.

Sometimes Columbus talked with travelers and told them about his dream of sailing west across the ocean to reach India. They always laughed at him.

One of them said, "If you sail far out on the ocean you will soon reach the Sea of Darkness. Its waters are boiling hot. You could never sail on them."

When Columbus said that he believed that the earth was round, some people would say, "How could the earth be round? The waters would all run off and all the people on the other side would drop off upside down." This kind of talk did not worry Columbus. He wanted to start on his trip to India, but he had no money. At last he went to King John of Portugal and told him his dream. He asked him to give him money to buy ships in which to sail to India and China. He promised to bring back silk and jewels so that Portugal would 
be the richest country in the world.

King John said, "I will help you if you will leave some of your charts and maps with me."

Columbus left the charts and maps, but King John did not use them. He gave them to some of his own sailors and told them to try to find China and India by sailIng west. The captain of the ship that King John sent out was afraid. When the first great storm came, he went back to Portugal. He told the king that there was no way to sail across the Atlantic.

When Columbus heard about this, he was angry. He said, "I will not stay in such a country that has such a wicked king. I will go to the king and queen of Spain. Perhaps they will help me."

\section{II}

Columbus had married, but his wife had died. He must care for their little son, Diego. Diego was only six years old.

When Columbus left Portugal he took Diego with him. They walked over the mountains to Spain. When Diego grew tired, his father carried him. At last they reached the palace of the king of Spain. King Ferdinand was too busy to listen to Columbus, 
because Spain was at war. Queen Isabella listened to his story and promised that she would help him when the war was over.

Columbus waited for many years, but he received no word from the queen.

"I will go to France," he said. "Perhaps the French King will help me."

While he was on his way to France, Columbus met a man who was a friend of Queen Isabella. When Columbus told him of his dream, he said, "Do not go to France. I will go to the queen and ask her to help you. The war is over now and I believe she will give you the money to buy some ships."

The good man talked with Queen Isabella about Columbus' dream. She sent for Columbus and listened once more to all that he said. She promised to get the money to pay for the ships.

At last three ships were ready to sail. They were called the Nina, the Pinta, ano the Santa Maria. With this little fleet Columbus sailed away from Palos, Spain, on August 3, 1492 . 


\section{A Great Dream Comes True}

At first the sailors on Columbus' three ships were happy because they believed that they would soon reach land. But when they had sailed for many weeks through strange waters they became frightened. They wanted to go back to Spain.

"There is no land farther west," they said. "This captain is crazy. Let us throw him overboard. Then we can turn the ships around and go home."

They begged Columbus to go back to Spain, but he only said, "Sail on! Sail on! and on and on!"

At last the sailors would not go any farther. "Give me just three more days," Columbus said. "Then if we find no land we will turn back."

The very next morning one of the sailors picked up from the sea a stick that had been cut. Then they saw a branch of a tree with red berries floating by. They saw sandpipers and a green reed near the ship. The sailors on board the Pinta saw a cane and a pole. Now everyone wanted to go on, for they thought land must surely be near.

This was on the eleventh day of October. About ten o'clock that night, columbus saw a light far away. It was like a wax candle moving up and down. He be- 
lieved that land must be near so he told all the sailors to keep a good look-out.

The Pinta was the fastest of the three ships, so she sailed ahead of the Santa Maria on which Columbus was sailing.

It was one of the sailors on this fast ship who first sew land. It was about two o'clock in the morning on October twelfth and they were still about eight miles from the shore. In less than an hour they reached a small island.

Columbus and the six captains went on shore. Kneeling, they gave thanks to God for taking care of them on the long voyage and for bringing them safely to these shores. He named this new island San Salvador which means Holy Saviour.

$\mathrm{He}$ thought that he reached the coast of India. He thought that his greatest dream had come true. But he had really discovered a New World. He had never even dreamed of doing anything as wonderful as that. 
The Natives of San Salvador

During his voyage, Columbus kept a journal or record of the things that happened day by day. Every night he would write what he had done that day. On the twelfth day of 0ctober, 1492 he wrote about the people that he found living on the island. He called them Indians because he thought that the land where they lived was a part of India.

He said, "They are the color of the people of the Canary Islands. They are neither black nor white. Some paint themselves white, others red, and others whatever color they can find. Some paint the whole body, others paint only around their eyes, others color only the nose. Their hair is coarse and short. It is like the hair of a horse's tail. In front their hair hangs down to the eyebrows. There are a few long locks in back which are never cut. Their eyes are very beautiful and not small. These people are very handsome and well made."

Columbus was very kind to these Indians and gave them red caps, glass beads to put around their necks, and small balls.

In return, the Indians gave the white men parrots and cotton thread in skeins. 
These Indians had never seen white men before and. they had never seen large ships. They believed that everything great and good was in Heaven, so they thought that Columbus and his sailors and ships had come down from Heaven. Some of them went on board the ships and traveled about with columbus and his men. At first the only way the white men ano the Inojians could talk to each other was by making signs. Later they were able to talk together by means of words.

Whenever columbus landed in a new place, the Indians who were on board his ships would go ashore and announce that the white people were coming. They would say, "Come, come, and see the folks from Heaven." Then the Indians would come down to the shore. They came in great crowds bringing rood and drink. Columbus said that they always treated him with the greatest kindiness.

We are glad that Columbus kept this record of his voyage to the New World and we are glad that he treated the Indians so kindly that they could believe that he had come down from Heaven. 
The Return of the Mad Sailor

In a corner of the palace some of the king's pages were gathered about one of their companions.

"Ho, Diego!" cried one of the boys. "What news tpday from the Mad Sailor?"

"When it is time for news from my father," answered Diego, "it shall be great news, I promise you!"

"Time!" cried one of the others. "It is nearly seven months since the Mad Sailor started out from Palos! Isn't seven months time enough? Long before this your father reached the edge of the world and sailed right over it. Down, down, he fell, he and his ships and his men!"

"The earth is round!" reolied Diego. "There is no edge to sail over. It is only foolish people who think so. My father will sail on and on. He will reach land on the other side of the world!"

"Iro-ho-ho!" laughed the boys. "The earth is round! Ho-ho-ho!"

"Everyone knows that the earth is flat, and that it rests on the back of a great turtle!" said a page named Gomez. "How round does the earth look to you, Diego? Look across the garden. Does it curve up or dorn? You have seen the great sea, haven't you? When 
the Mad Sailor set out for the west, was he sailing up hill? Ho-ho-ho:"

"If the earth is round," said another page, laughing, "what about the people on the other side? If there are people under us, they must be walking with their heads down and their heels upward!"

"Yes," laughed another, "and in that land, I suppose it rains and snows upward."

"My father says that in those countries, down is toward the earth, and up is toward the sky, just as it is here," answered Diego.

"There are terrible monsters in the Sea of Darkness," said Gomez. "They will swallow your father's three ships at one mouthful."

"It is not so!" replied Diego. "The sea is just the same blue sea that we see here at palos. Far to the west are wonderful islands. Farther still are the shores of India. My father will find them."

Suddenly a messenger ran into the garden where the boys were talking. "The son of Columbus!" he called loudly. "Where is he? The queen sends for him! The great Columbus has found the land beyond the sea! A message has just come from him!" 
The pages fell back in surprise and shame as Diego proudly followed the messenger to the queen. The king and the queen and the proudest nobles of the court had met to do honor to the Mad Sailor. Diego did not even think of the king and queen. He only saw - his father who was standing before the throne. With him were some strange dark people dressed in the skins of wild beasts.

Diego ran forward, and in another moment he was clasped in his father's arms. 
Bibliography 


\section{Bibliography}

1. References Used in Writing Thesis

\section{A. Books}

Gates, Arthur I., The Improvement in Reading, The Macmillan Company, New York, 1935

Good, Carter V., Barr, A.S., and Scates, Douglas E., The Methodology of Educational Research, D. AppletonCentury Company, New York, 1938

Harris, Albert J., How to Increase Reading Ability, Longmans, Green and Company, New York, 1941

McKee, Paul, Language in the Elementary School, Houghton Mifflin Company, New York, 1934

McKee, Paul, Reading and Literature in the Elementary School, Houghton Mifflin Company, Boston, 1934

Monroe, Walter S., and Engelhart, Max D., The Scientific Study of Educational Problems, The Macmillan Company, New York, 1935

Olcott, Frances Jenkins, Good Stories for Anniversaries, Houghton Mifflin Company, Boston, 1937 
0lcott, Frances Jenkins, Good Stories for Great Holidays, Hought on Mifflin Company, New York, 1914

Retold from St.Nicholas, Our Holidays, Their Meaning and Spirit, The Century Company, New York, 1905

Stone, Clarence R., Better Primary Reading, Webster Publishing Company, St.Louis, 1936

Thl, Willis L., The Materials of Reading, Silver Burdett and Company, New York, 1924

Wickes, Frances G., Happy Holidays, Rand McNally and Company, Chicago, 1928 


\section{B. Courses of Study}

Baltimore, Maryland, (County), 1937

California State Department of Education, Sacramento,1922

Cincinnati, Ohio, 1926

Cleveland, Ohio, $1927-1929$

Denver, Colorado, 1931

Detroit Public Schools, 1925

Fort Worth, Texas, 1935

Iowa State Course of Study for Elementary Schools, 1930

Kansas City, Missouri, 1930

Long Beach, California, 1930

Los Angeles, California, Grade 2, 1924

Louisville, Kentuciry, A Preliminary Course of Study

in English for Kindergarten-Primary Grades, 1940

Milwaukee, Wisconsin, $1936-1937$

Minneapolis, Minnesota, 1935

Oklahoma City, Oklahoma, 1936 - 1937

Pasadena, California, 1936

Raleigh, North Carolina, (Grades 1,2,3) 1928 - 1931

Raleigh, North Carolina, Social Studies Courses of

Study, 1936

St.Louis, Missouri, 1926

State of Indiana, 1930

Virginia State Course of Study, 1937 


\section{c. Magazine Articles}

Wooley, Edwin C., and scott, Frankiin w., College Handbook of Composition, D. C. Heath and Company, New York, 1928

"The Journal of Columbus", The Golden Book Magazine, II (October, 1925) 471-474

Morgan, John Elmer, "Between Editor and Reader", The Journal of the National Education Association, $\mathrm{XXX}$ :II (February, 1941) 21

Kerbey, McFall, "Genoa, Where Columbus Learned to Love the Sea," The National Geographic Nagazine, IIV (September, 1928) 333-352 


\section{Monograph}

Gates, Arthur I., A Reading Vocabulary for the Primary Grades, pp.5-20, Bureau of Publications, Teachers College, Columbia University, New York, 1935 
II Stories To Be Adapted and Source Materials

\section{A Holidays in General}

Bailey, Carolyn S., The Wonderful Days, Albert Whitman and Company, Chicago, 1925

Conover, Charlotte, Selected by, A Holiday Story

Sampler, The Junior Literary Guild, New York, 1941

State of New Jersey Department of Public Instruction, Special Days and Their Observance, Trenton, New Jersey, 1919

Harrington, Mildred P., and Thomas, Josephine H., compiled by, Our Holiday in Poetry, The H.H.Wilson Company, New York, 1938

Lawson, Robert, Watchwords of Liberty, A Pageant of American quotations, Little, Brown and Company, Boston, 1943

McSpadden, John Walker, Book of Holidays, The Thomas Y. Crowell Company, New York, 1927

Olcott, Frances Jenkins, Good Stories for Great Deys, Houghton Mifflin Company, New York, 1914

Olcott, Frances Jenkins, Good Stories for Anniversaries, Houghton Mifflin Company, Boston, 1937 
Paulmier, Hilah, and Schauffler, Robert Haven, Democracy Days, Dodd, Mead and Company, New York, 1942

Paulmier, Hilah, and Schauffler, Robert Haven, Pan-American Day, Dodd, Mead and Company, New York, 1943

Retold from St.Nicholas, Our Holidays, Their Meaning and Spirit, The Century Company, New York, 1905

Sechrist, Elizabeth Hough, Red Letter Days, MacraeSmith Company, Philadelphia, 1940

Wickes, Frances G., Happy Holidays, Rand McNally and Company, Chicago, 1928 


\section{B Columbus Day}

Gordy, W. F., Stories of American Explorers, Charles Scribner's Son, New York, 1906

Grady, Edward and Others, Childhood Readers, New Stories for Boys and Girls, Charles Scribner's Son, New York, 1938

Meadowcraft, Enid LaMonte, Ship Boy With Columbus,

Thomas Y. Crowell Company, New York, 1942

Morison, Samuel Eliott, Columbus, Admiral of the ocean Sea, Little, Brown and Company, Boston, 1942

Paulmier, Hilah and Schauffler, Robert Haven, Columbus Day, Dodd, Mead and Company, New York, 1938 Wilson, Howard Eugene, Where Our Ways of Living Come From, American Book Company, Cincinnati, 1937 


\section{Thanksgiving}

Elson-Gray Basic Reader, Book 4, Scott, Forsman and Company, Chicago, 1936

English, Mildred and Alexander, Thomas, Wheels Westward, Johnson Publishing Company, Richmond, Virginia, 1938

Halleck, Reuben Post, and Frantz, Juliette, Founders of Our Nation, American Book Company, New York, 1929

Heard, Sarah Dow, and King, Morrill Whitney, Stories of American Pioneers, John C. Winston Publishing Company, Philadelphia, 1929

Pumphrey, Margaret, Pilgrim Stories and Plays, Rand McNally and Company, Chicago, 1932

Knowlton, Daniel Chauncey, and Others, When We Were Colonies, American Book Company, Cincinnati, 1934

Tillinghast, I. Morton, Colonial Life in America, G. P. Putman's Sons, New York, 1928 Warren, Maude Lavina Raoford, Little Pioneers, Rand McNally and Company, Chicago, 1933 Waston, Elizabeth, Story of Bread, Harper Brothers, New York, 1927 


\section{Lincoln's Birthà ay}

Barton, William, The Life of Abraham Lincoln, Books, Inc. Boston, 1943

Buckley, Horace Mann, and Others, Around the Year, American Book Company, Cincinnati, 1938

Elson, William Harris, Elson Gray Basic Reader, Book 6 , Scott Foresman and Company, Chicago, 1936

Heard, Sarah Dow, and King, Morrill Whitney, Stories of American Leacers, John C. Winston Company, Philadelphia, 1934

Hertz, Emanuel, The Hidden Lincoln, Blue Ribbon Books Garden City, New York, 1940

Meadowcrpft, Enid Lalionte, Abraham Lincoln, Thomas $Y$. Crowell Company, New York, 1942

Meigs, Cornelia Lynde, Young Americans, Ginn and Company, Boston, 1936

Shaw, Albert, Abraham Lincoln, His Path to the Presidency, Grosset and Dunlap, New York, 1929

Stevenson, Augusta, Abe Lincoln, Frontier Boy, BobbsMerrill Company, Indianapolis, 1932 
Theisen, William Walter and Leonard, Sterling A. Heroic Deeds, The Macmillan Company, New York, 1931

Walker, Alberta, and Parkman, Mary R., Study Readers, Book 5, Bobbs-Merrill Company, Indianapolis, 1933

Wall, Bernhardt, Following Lincoln, Wise-Parslow Company, New York, 1943 
E. Washington's Birthday

Bedayere, Michael DeLa, George Washington, J.B. Lippincott Company, Philadelphia, 1935

Elson, Williain H., Elson-Gray Basic Reader, Book 6 , Scott Foresman and Company, New York, 1936

Foster, Genevieve, George Washington's World, Charles Scribner's Son, New York, 1941

Grady, William Edward, New Stories of Today and Yesterday, Charles Scribner's Son, New York, 1938

Little, Shelby, George Washington, Halcyon Publishing Company,New York, 1943 


\section{F. Memorial Day}

Elson, William H. and Gray, William S., Elson-Gray

Basic Reader, Book 5, Scott, Foresman and Company, Chicago, 1936

Schauffler, Robery Haven, Memorial Day, Dodd-Mead and Company, New York, 1911 
G. Flag Day

Elson, William H., Elson-Gray Basic Reader, Book 4, Scott, Foresman and Company, Chicago, 1936

Heard, Sarah Dow, Stories of American Pioneers, John C. Winston Company, Philarelphia, 1937

Moss, James A., The Flag of the United States, Its History and Symbolism, The United States FIag Association, Washington, D.C. 1941

Quaife, Milo Milton, The Flag of the United States, Grosset and Dunlap Publishing Company, New York, 1942 
H. Magazine Article

McNeil Anna W., The Stax Spangled Banner, The Etude Magazine, LV (JuIy, 1937) pp.432-455 
I. Monographs

Suggested Course of Study in Flag Eaucation, American Legion

Laws Relating to United States Flag and the Flag Code, Nary Department, United States

How to Respect and Display Our Flag, Unites States Marine Corps, Publicity Bureau, Washington, D.C.

United States Flag, United States Office of Education in Cooperation With United States Flag Association, Washington, D.C. 
III Stories To Be Read By Prinary Children

A. Columbus Day

Elson, William H., and Gray, William S., Elson-Gray Basic Reader, Third, Scott, Foresman and Company, Chicago, 1936

English, Mildred, Wide Windows, Johnson Publishing

Company, Richmond, Virginia, 1935

Hildreth, Gertrude, and Others, The Story Road,

John C. Winston Company, Philadelphia, 1940

Leavell, Ullin W., and others, Indoors and out, The American Book Company, Cincinnati, 1935

Leavell, Ullin W., and Others, Plamates, First Reader, The American Book Company, Cincinnati, 1935

Lowitz, Sadyebeth and Anson, The Cruise of Mr. Christopher Colurabus, Grosset and Dunlap, Publishers, New York, 1932

Martin, Cora M., New Stories and 0ld, Charles Scribner's Sons, New York, 1934 
Quinlan, Myrtle Banks, Busy World, Allyn and Bacon, New York, 1940

Waddell, John Franklin, Long Ago, The Macmillan Company, New York, 1933 


\section{B. Thanksgiving Day}

Bryce, Catherine T., and Hardy, Rose Lees, the open Door Reader, Nevsom and Company, Publishers, New York, 1927

Elson, William H., and Gray, William S., Elson-Gray Basic Reader, Second, Scott, Foresman and Company Chicago, 1936

Gates, Arthur I., and Others, Wide Wings, The Macmillan Company, New York, 1939

Leave11, Ullin W., and Others, Playmates, First Reader, The American Book Company, Cincinnati, 1935

English, Mildred, Wheels and Wings, Johnson Publishing Company, Richmond, Virginia, 1935

Hildreth, Gertrude, and Others, The Story Road, John C. Winston Company, Philadelphia, 1940

Kinscella, Hazel Gertrude, Man in the Drus and other Tales, University Publishing Coinpany, Chicago, 1939

Malester, Amelia, We Look Around Us, Augsburs Publishing Compony, Morristow, Tenn. 1937

Meadowcroft, Enid Lamonte, First Year, A Story of the Pilgrims in America, The Thomas $Y$. Crowell Company, New York, 1937 


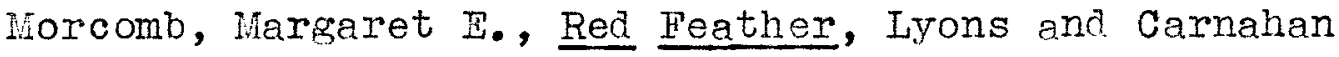
Company, Chicago, 1938

Pennell, Mary Elizabeth, and Cusack, Alice M., Children's Owm Readers, Book 2 , Ginn and Company, Boston, 1936

Schenk, Esther Mary, Thankssiving Time, Lyons and Carnahan Company, Chicago, 1937

Stone, Clarence Robert, Joyful Trails, Webster Publishing Company, St.Louis, 1940

Stone, Clarence $R_{\bullet}$, and Stone, Anne L., New Trails in Reading, Webster Publishing Company, St.Louis, 1940 Waddell, John Franklin, and Others, Long Ago, The Macmillan Compeny, New York, 1937 


\section{Lincoln's Birthday}

Aulaire, Me. Ingri kortenson $D^{\prime}$ and Aulaire, Edgar Parin $D^{\prime}$, Abraham Lincoln, Doubleday, Doran and Company, Inc., Garden City, New York, 1939

Bryce, Catherine T., and Hardy, Rose Lees, The Open Door, Newsom and Company, Publishers, New York, 1927

Davidson, Isobel, The Lincoln Reader, Third Reader, Laurel Book Company, Chicago, 1928

Elson, William H., and Gray, William S., Elson-Gray Basic Reader, Book 2 , Scott, Foresman and Company, Chicago, 1936

Elson, William H., and Gray, William S., Elson-Gray Basic Reader, Book 3, Scott, Foresman and Company, Chicago, 1936

Leavell, Ullin W., and others, Friends to Pnow, The American Book Company, Cincinnati, 1935

Lowitz, Sadyebeth and Anson I., Barefoot Abe, Grosset and Dunlap, Publishers, New York, 1938

McLester, Amelia, Let's Read, Augsourg Publishing Company, Morristom, Tenn. 1937 
Petersham, Elaud and Miska, An American $\underline{A B C}$, The

Macmillan Company, New York, 1941

Stevenson, Augusta, Abe Lincoln, Frontier Boy, The

Bobbs-merrill Company, Indianapolis, 1932

Waddell, John Franklin, Long Ago, The Macmillan Company, New York, 1953 


\section{Washington's Birthday}

Aulaire, Mre. Ingri Nortenson $D ;$ and Aulaire, Edgar Parin $D^{\prime}$, George Washington, Doubleday, Doran and Company, Garcen City, New York, 1936

Baker, Clara Belle, and Baker, Edna Dean, Sailing Tub and other Stories, Bobbs-lírrill Company, Indianapolis, 1938

Bryce, Catherine T., and Hardy, Rose Lees, The Open Door Reader, Newsom and Company, publishers, New York, 1927

Davidson, Isobel, The Lincoln Reader, Third Reader, Laurel Book Company, Chicago, 1928

Elson, William H., and Gray, William S., Elson-Gray Basic Reader, Seconc, Scott, Foresman anỏ Company, Chicago, 1936

Elson, William H., and Gray, William S., Elson-Gray Basic Reader, Third, Scott, Foresman and Company, Chicago, 1936

Inglish, Mildred, and Alexander, Thomes, Wheels and Wings, Johnson Publishing Company, Richmond, Virginia, 1935 
Fnglish, Mildred, and Alexander, Thomas, Wide Vindows, Johnson Publishing Company, Richrond, Virginia, 1935

Gray, William Scott, and Others, More Streets and Roads, Scott, Foresman and Company, Chicago, 1942

Lowitz, Sadyebeth and Anson, General George the Great, Grosset and Dunlap, Inc., New York, 1932

Martin, Cora in., New Stories and old, Charles Scribner's Sons, New York, 1934

Milhous, Katherine, Corporal Keeperupper, Charles Scribner's Sons, New York, 1943

Stone, Clarence Robert, Joyful Trails, Webster Publishing Company, St.Louis, 1935

Stone, Clarence R., and Stone, Anne I., New Trails in Reading, Webster Publishing Company, St.Louis, 1935

Storm, Grace, Neighbors and Helpers, Lyons and Carnahan, Chicago, 1940 


\section{E. Flag Day}

Aulaire, Ingri and Edgar Parin $D^{\prime}$, The Star Spangled Banner, Doubleday, Doran and Company, Inc., Garden City, New York, 1942

Baker, Clara Belle, and Baker, Edna, Fifty Flags, Bobbs-Merrill Company, Indianapolis, 1928

Baker, Clara Belle, and Baker, Edna Dean, Sailing Tub and other Stories, Bobbs-Merrill Company, Indianapolis, 1938

English, Mildred, and Alexander, Thomas, Wheels and Wings, Johnson Publishing Company, Richmond, Virginia, 1935

Grover, Beatrice B., Broad Stripes and Bright Stars, The Greystone Press, Inc., New York, 1941

Kinscella, Hazel Gertrude, Storyland, University Publishing Company, Chicago, 1938

Michaels, Fannie L., All Around Us, Beckley-Cardy Publishing Company, Chicago, 1942

Smith, Etta May, Salute the Flag, Albert Whitman and Company, Chicago, 1941

Stone, Clarence Robert and Others, Joyful Trails, Webster Publishing Company, St.Louis, 1940 
Appendix 
QUESTIONNATRE

on

PATRIOTIC HOLIDAY READING MATERIALS

for

GRADES 1,2 and 3

NAMEE

SCHOOL

GRADE

1. In your grade is there a need for reading material suitable for use on patriotic holidays?

2. Check the holidays for wich you need reading material.

Labor Day

Columbus Day

Armistice Day

Thanksgiving

Abraham Lincoln

George Washington

Memorial Day

Flag Day

3. Do you think an anthology of patriotic holiday stories would be of value to a primary teacher?

Suggestions 
Copies of the tentative criteria were sent to forty-six superintendents and supervisors with the following responses:

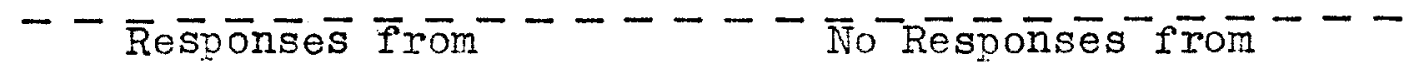

1. Albuquerque, N. Mex. 1. Boise, Idaho

2. Athens, Ohio

2. Charleston, S. Car.

3. Atlanta, Ga.

3. Chicago, Illinois

4. Baltimore, nd.

4. Cincinnati, 0 .

5. Buffalo, N. $Y$.

5. Cleveland, 0 .

6. Denver, Colo.

6. Dallas, Texas

7. Indianapolis, Ind.

7. Detroit, Mich.

8. Kansas Gity, Mo.

9. Iittle Rock, Ark.

8. University of Indiana Indianapolis, Ind.

9. Iowa City, Iowa

10. Louisville, Ky.

11. Manchester, New Hamp.

10. University of Iowa Iowa City, Iowa

12. Memphis, Tenn.

11. Long Beach, Cal.

13. Milwaukee, Wis.

12. Los Angeles, Cal.

14. Minneapolis, Minn.

13. Miami, Fla.

15. Oklahoma City, Okla.

14. Montpelier, Ver.

16. Nashville, Tenn.

15. Newark, New Jer.

17. Philadelphia, Penn. (3)

16. New Orleans, La.

18. Portiand, Me.

17. New York City, N.Y.

19. Portland, Ore.

18. Omaha, Neb.

20. Richmond, Va.

19. Pasadena, Cal.

21. Sacramento, Cal.

20. Providence, R.I.

22. St.Louis, Mo.

21. Raleigh, N. Car.

22. St.Paul, Minn.

23. Seattle, Wash.

24. Washington, D. C.

(1) did not fill out questionnaire-against policy of department to assist students in assignments.

(2) refused to fill out questionnaire-wrote letter of regret.

(3) too busy with war work to answer questionnaire. 
Louisville, Kentucky 1330 Hemlock Street March 31, 1943.

Dear Primary Supervisor:

In connection with the thesis that I am writing for my M. A. degree at the University of Louisville, on Patriotic Foliday Reading Material for Primary Grades, I am asking your help. Will you please score those criteria needed which you would use in judging material to be used in the Prinary Grades?

Please return your reply in the enclosed self-addressed envelope.

preciated.

Your help will be greatly ap-

Very truly yours,

P.S.

Why did you make no suggestions for patriotic holiday activities in your course of study? 


\section{Hemlock Street, Louisville, Kentuckv. July 30, 1942.}

Rand McNally and Company, Chicago, Illinois.

Dear Sirs:

In connection with the thesis that I am writing on Petriotic Holiday Reading Material for Primary Grades, I wish to sent into the schools of Louisville some stories for examination by teachers and pupils. Approximately fifteen schools in this city will participate in this survey. Therefore, I would like to send sixteen mimeographed copies of the selected stories into each school. Six of these stories have been prblished in Haopy Holidavs by Frances vickes.

I am rriting to ask your permission to use in this way the following stories: A Little Boy of Genoa, A Dream That Game True, The Return of the Mad Sailor, The Simnlest Thing in All the World, Half a League onward, an The Little Victor. This thesis is not for publication. Verv truly vours, 
$\begin{array}{lllll}C & O & P & Y\end{array}$

Chicago, Illinois.

August 6, 1942 .

Miss Mary Walker Barnard,

1330 Hemlock Street,

Louisville, Kentucky.

Dear Miss Barnard:

We have your letter of July 31 in which you asls our permission to use the following selections from HAPPY HOLIDAYS by Frances G. Wickes in your thesis: "A Little Boy of Genoa", "A Dream That Came True", "The Return of the laad Sailor", "The Simplest Thing in All the World", "Half a League Onward", "The Little Victor".

We are pleased to grant this permission. As is customary in such cases, we shall expect that proper credit be given to Rand McNelly and Compeny as publishers of the materials.

With all good wishes for your work, we are

Very truly yours,

signed Aleigh R. Hough

Rand McNally and Company

Managing Editor

Education Division

$\mathrm{ARH}: \mathrm{hb}$ 


\section{$\begin{array}{llll}\mathrm{C} & 0 & \mathrm{P} & \mathrm{Y}\end{array}$}

September 25, 1942

To the Principals of the Elementary Schools:

Mary Walker Barnard has some material on Columbus which may be appropriate for use in preparing for Columbus Day. One of your third grade teachers may accept the material and use it as she sees fit in preparing any work which ordinarily might be done in the third grade for the observance of thst day. She would like to consult with the teacher after school hours.

Very truly yours,

(signed) C. A. Rubado

Assistant Superintendent

$C A R: P L$ 